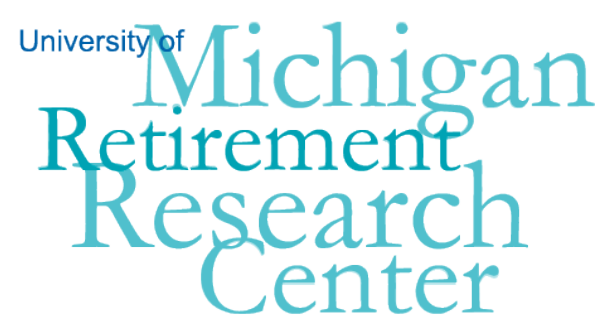

Working Paper WP 2013-298

\title{
Cognitive Ability, Expectations, and Beliefs about the Future: Psychological Influences on Retirement Decisions
}

Andrew M. Parker, Leandro S. Carvalho, and Susann Rohwedder

\begin{tabular}{|l|l|}
\hline $\mathrm{M}$ & $\mathrm{R}$ \\
\hline $\mathrm{R}$ & $\mathrm{C}$ \\
\hline
\end{tabular}

Project \#: UM13-Q4 



\title{
Cognitive Ability, Expectations, and Beliefs about the Future: Psychological Influences on Retirement Decisions
}

\author{
Andrew M. Parker \\ Leandro S. Carvalho \\ Susann Rohwedder \\ RAND
}

September 2013

\author{
Michigan Retirement Research Center \\ University of Michigan \\ P.O. Box 1248 \\ Ann Arbor, MI 48104 \\ www.mrrc.isr.umich.edu \\ (734) 615-0422
}

\section{Acknowledgements}

This work was supported by a grant from the Social Security Administration through the Michigan Retirement Research Center (Grant \# 5 RRC08098401-05-00). The findings and conclusions expressed are solely those of the author and do not represent the views of the Social Security Administration, any agency of the Federal government, or the Michigan Retirement Research Center.

\section{Regents of the University of Michigan}

Mark J. Bernstein, Ann Arbor; Julia Donovan Darlow, Ann Arbor; Laurence B. Deitch, Bloomfield Hills; Shauna Ryder Diggs, Grosse Pointe; Denise Ilitch, Bingham Farms; Andrea Fischer Newman, Ann Arbor; Andrew C.

Richner, Grosse Pointe Park ; Katherine E. White, Ann Arbor; Mary Sue Coleman, ex officio 


\title{
Cognitive Ability, Expectations, and Beliefs about the Future: Psychological Influences on Retirement Decisions
}

\begin{abstract}
Recent advances in behavioral decision research, behavioral economics, and life-span development psychology provide leverage for expanding our understanding of the decision to retire earlier versus later. This report examines how cognitive abilities, perceptions about the future, and other psychological characteristics affect retirement decisions. We use existing and new data collected through the RAND-USC American Life Panel, including detailed assessments of fluid and crystallized intelligence, financial literacy, expectations for the future, future time perspective, and maximizing versus satisficing decision styles.

We find those with high levels of cognitive ability are more likely to retire later, as are those with greater longevity expectations. We also find those with lower cognitive ability have less coherent expectations of retirement-suggesting a need for planning assistance. We also find expectation of lower Social Security benefits is associated with plans to retire latercontrary to our hypothesis that such expectation might spur early retirement in an effort to lock in benefits. Finally, we find that tendencies to maximize (versus satisfice) had mixed effects on retirement decision making, with different aspects of maximizing tendencies showing different relationships with retirement decision making.

Future work should expand these data in a targeted direction. Recent research notes that decision-making competence can be improved with training, and to the extent this trainability extends to older adults, decision skills may be a useful target for intervention. Stronger longitudinal design and analysis can also help demonstrate possible endogeneities between retirement and psychological variables.
\end{abstract}

\section{Citation}

Parker, Andrew M., Leandro S. Carvalho, and Susann Rohwedder (2013). "Cognitive Ability, Expectations, and Beliefs about the Future: Psychological Influences on Retirement Decisions.” Ann Arbor MI: University of Michigan Retirement Research Center (MRRC) Working Paper, WP 2013-298. http://www.mrrc.isr.umich.edu/publications/papers/pdf/wp298.pdf

\section{Authors' Acknowledgements}

This research was funded by the Social Security Administration (SSA), through the Michigan Retirement Research Center (MRRC), project UM13-Q5. The statements here reflect the views of the authors and do not necessarily reflect the views of the SSA or MRRC. The authors wish to thank Michelle Horner and Clifford Grammich for their assistance in preparation of this manuscript, and Michael Hurd, Erik Meijer, and Marco Angrisani for their insights into the design of this project. 


\section{Introduction and Background}

Past research has shown socio-economic status and health considerations (both personal and family) affect decisions when to retire and claim social security benefits. For example, Brown et al. (2010) show that wealth shocks induce earlier retirement. Also, the economic incentives created by pension rules strongly influence the timing of retirement (Gruber and Wise, 1999). Several studies have shown that deteriorations in health lead to early retirement (e.g. Disney et al., 2006). French (2005) compares the importance of poor health for the timing of retirement to that of other economic incentives.

Such work, however, has largely ignored psychological influences that may also explain individual decisions on when to retire. Recent advances in behavioral decision research, behavioral economics, and life-span development psychology can help us expand our understanding of the timing of retirement. This includes increased availability of data on retirement age and expectations, cognitive abilities and financial literacy, beliefs about the future, and decision-making styles, as well as how these vary by demographic characteristics. Together, these provide new tools for understanding how retirement decisions are affected by ability to think through complex planning decisions, perceptions about the future (both personal and that of programs such as Social Security), and perceived tradeoffs in planning for it.

Understanding the psychological underpinnings of retirement timing could better inform interventions to support coherent retirement decisions. For example, individuals with lower cognitive abilities (which are known to change with age) may benefit more from decision aids that provide assistance when considering tradeoffs, particularly complex ones.

Furthermore, much of the existing research has focused on early retirement, rather than late retirement, because of the large fraction of retirees leaving the labor force before age 65 . However, with increasing financial pressures on entitlement programs like Social Security and Medicare there has been discussion of increasing the ages of eligibility. In fact, the Social Security eligibility age for full benefits is gradually increasing from age 65 for older cohorts to age 67 for more recent cohorts. Therefore there is growing interest in what leads some people under the current system to work longer than others. In this study, we extend prior research on decisions of when to retire and claim social security benefits in two ways. First, we leverage existing and new data available on multiple cognitive and psychological characteristics, which have been collected in the same panel study along with a rich set of demographic, economic, and health variables. Second, we focus more than previous research has done on decisions to retire and claim Social Security benefits late, rather than early or on time. 


\section{Role of Psychological Characteristics in Retirement Decisions}

"Many people may simply claim benefits immediately at age 62, without taking into account the far-reaching financial effects of this uptake decision” (Knoll, 2011, p. 17).

The decision of when to retire requires an individual to trade off diverse considerations, and systematically doing so can be a cognitively demanding task. This includes Social Security benefits, which vary by birth cohort and age of retirement, foregone earnings and opportunities for other forms of employment, and opportunities to explore other interests, including new leisure activities (e.g., travel), time with family, and personal growth (e.g., learning a new skill). Furthermore, given that many of these considerations occur only in the future, weighing them against each other involves substantial uncertainty. Most notably, an individual does not know how long she will live, so calibrating her available resources to future needs is a significant problem. A potential retiree also may not know how well she will adapt from a career and regular work schedule to a less-structured and less-scheduled retirement life. Pursuing opportunities for personal growth may or may not pan out as planned, and existing career options may turn out better or worse than anticipated.

The ability to think through retirement decisions will, in part, vary by cognitive abilities, which in turn vary across individuals. Cognitive abilities can broadly be categorized into fluid cognitive abilities, which includes problem-solving capacity and typically decline with age, and crystallized cognitive abilities, which reflect knowledge and experience gained over time and maintained with age (McArdle et al., 2002). Age-related declines in fluid cognitive ability have been linked to decision-making deficits, but age-related gains in crystallized cognitive abilities may compensate for losses in fluid abilities (Bruine de Bruin et al., 2012; Finucane \& Gullion, 2010; Henninger et al., 2010; Hess et al., 2012; Wood et al., 2011). Financial literacy, which focuses largely on financial knowledge, might be considered a domain-specific form of crystallized cognitive ability, or at a minimum the two are closely tied. In general, however, lower cognitive abilities (including financial literacy) may result in less-reasoned retirement decisions. Those with a greater store of relevant life experiences and greater ability to process complex financial information may be more likely to incorporate financial aspects of decisions, or do so in a systematic and well-reasoned way. Without such abilities, individuals may neglect this information, focusing on other (admittedly relevant) information, such as job satisfaction. Given that many reasons to retire later are financial, those with greater ability to process this information may be more likely to see value in retiring later. Finally, those with more diminished cognitive abilities may find continued employment difficult and leave the workforce earlier. Hence, we hypothesize the following:

H1: Those with greater cognitive abilities, including financial literacy, will be more likely to retire later. 
Expectations of the future are central in both psychological and economic models of decision making (see, e.g., Fischhoff \& Beyth-Marom, 1983; Manski, 2004) and may be influenced by the characteristics of an individual or the context in which an individual finds herself. For this very reason, as discussed in detail below, we examine expectations for working full-time later in life (i.e., delayed retirement) as an important aspect of retirement decision making, as well as expectations for other factors that may influence retirement decision making.

One important aspect of expectations is that their value in retirement decision making may depend on how well-formed they are (i.e., their validity). In most cases accuracy may be judged only with the passage of time (e.g., whether you actually work full-time after age 62). We may, however, judge expectations for another aspect of validity - their coherence. For example, the probability one sees for "working full-time after age 65" should be no more (if not less) than the probability for "working full-time after age 62." ${ }^{1}$ Incoherence in such expectations, e.g., rating one's probability of working after age 65 higher than one's probability of working after age 62, may reflect poor thinking about the future. Because such ratings are essentially a cognitive exercise, we would expect individuals with higher cognitive abilities to be more capable of generating coherent expectations. Such coherent expectations should, in turn, provide more wellreasoned inputs to retirement decisions. This leads to our second hypothesis.

H2: Those with greater cognitive abilities will have more coherent retirement expectations.

In terms of factors that influence retirement decision making, we consider two types of expectations. Longevity expectations should affect retirement decisions, because the longer one expects to live will dictate how much retirement income is required for the desired living standard. Expectation of a longer life may also encourage later retirement, given that greater monthly Social Security benefits resulting from delayed retirement may be enjoyed over a longer remaining life span. Conversely, expectation of future reduction in social security benefits (e.g., through legislative reform) may encourage earlier retirement to lock in the current benefit structure. Expectations regarding longevity and Social Security reform provide our next two hypotheses.

H3: Those with greater longevity expectations retire later.

H4: Those with greater expectation of future Social Security reform reducing personal benefits will retire earlier.

Whereas H4 is our primary hypothesis regarding Social Security reform, an alternative hypothesis is that the uncertainty about Social Security reforms could lead individuals to

\footnotetext{
${ }^{1}$ This property is also known as monotonicity in expectations.
} 
anticipate a need to retire later, in order to make up for the reduction in the Social Security benefits. In either case, because the hypothesized mechanism most clearly involves anticipation of retirement (rather than actual retirement), this suggests a stronger relationship between Social Security expectations and retirement expectations than between Social Security expectations and actual retirement age itself.

Recent advances in life-span developmental psychology have found beliefs about the future can greatly influence planning decisions. Socio-emotional selectivity theory (Carstensen, 2006) emphasizes age-related changes in future time perspective, such that older people see the future as more limited and less full of opportunities (Cate and Johns, 2007). Such perspective may cause individuals to seek positive emotional experiences - essentially, making the most of their remaining time - perhaps at the expense of monetary and other considerations. This yields our fifth hypothesis.

H5: Those focusing on opportunities (i.e., seeing a more expansive future) will choose later retirement, while those focusing on limitations will choose earlier retirement.

Finally, research on decision-making styles highlights how individual tendencies to seek an optimal choice (i.e., maximize), rather than one that is good enough (i.e., satisfice), can improve attainment of certain goals (e.g., high income) but at emotional costs (e.g., greater regret, lower satisfaction) (Schwartz et al., 2002; Iyengar, et al., 2006). Self-reported maximizers perform worse on decision-making tasks and reported more negative life outcomes (Parker et al., 2007). Analyses by Nenkov and colleagues (2008) suggests that the maximizing construct has three distinct components: having high standards, continually searching for better alternatives in one's

life, and experiencing decision difficulty (due to the complexity of maximizing within complex choices). All else equal, we expect maximizers, and in particularly those who continually search, to retire later to optimize earnings (but perhaps realizing lower life satisfaction). This leads to our sixth hypothesis.

H6: Those endorsing maximizing behavior, particularly those who continually search for better alternatives, will retire later.

\section{Leveraging Existing Psychological Data}

To assess these hypotheses, we leverage a unique database, the American Life Panel (ALP). The ALP is an ongoing internet panel study that combines rich data on cognitive abilities, expectations, future time perspective, and maximizing tendencies with in-depth data on demographic, economic, and health variables. We will use its psychological questions to predict retirement timing, characterized in three ways. First, for those approaching retirement age, we will examine retirement expectations (i.e., whether respondents expect to be working full-time at 
specified ages). Second, for those past retirement, we will analyze reported retirement age and how it compares to ages for claiming full or partial Social Security benefits. Third, because retirement planning may depend on more than Social Security benefits, we will assess a newlyfielded survey of recently-retired persons on whether retirement was earlier than expected, as expected, or later than expected.

The results of this study will help improve the ability to forecast retirement and claiming decisions. This, in turn, can improve the ability of the Social Security Administration to design policies accurately reflecting retirement behavior and suggest means to improve retirement decision making.

In the next section, we discuss the ALP and its measures. In the third section, we present our analyses of ALP data. In the fourth and concluding section, we summarize how well the data support our hypotheses and the implications of our results. 


\section{Approach}

\section{Sample}

\section{American Life Panel}

The ALP is an ongoing internet panel run by RAND and the University of Southern California of more than 6,000 respondents age 18 and older who regularly participant in internet surveys (https://mmicdata.rand.org/alp/). The majority of panelists have their own internet access, but the panel avoids possible bias resulting from Internet access by giving a computer and Internet access to those lacking it. Panelists have been recruited in a number of ways, including from the University of Michigan’s Survey Research Center Monthly Survey (which recruited using random digit dialing), referrals from existing panel members, Stanford University and Abt SRBI's National Survey Panel (which recruited door-to-door), and through an ongoing mail method to refresh recruitment. Interview data are reweighted to match the Current Population Survey's distributions on demographic characteristics and income. In addition to a demographic battery of questions, the ALP includes special topics rotated over time, as well as a battery of questions replicating those in the Health and Retirement Study.

Table 2.1 summarizes which ALP surveys supplied each of the main constructs in our analyses. The subsequent section describes each variable specifically.

\section{Existing Data}

To use ALP data across time, we merged data from each survey using a common respondent identifier. We restricted our analyses to respondents at least forty-five years old and who had non-missing values for at least one of our dependent variables, which we discuss in greater detail below.

\section{New Survey}

We also fielded a new survey for this project with panelists who reported having retired in the past five years (for whom we expect recall to be the best). The survey asked participants whether they had retired earlier than they expected, about when they expected, or later than they expected. It also asked reasons for retirement and why the actual time of retirement may have differed from that expected. 
Table 2.1. Summary of main study constructs and ALP survey waves.

Construct

Dependent

Retirement age

Retirement expectations

Expected retirement age

Whether retirement age was as expected

Independent

Cognitive ability

Future time perspective

Longevity expectations

Social security expectations

Financial literacy

Maximizing tendencies

Demographics (including gender, marital

status, education, and age)

Health Status and Wealth
ALP Survey Wave or Dataset

RAND ALP HRS, ${ }^{a}$ supplemented by

quarterly demographic surveys, as

described below

RAND ALP HRS

RAND ALP HRS

Wave 357 (new survey)

Wave 286

Wave 226

RAND ALP HRS

RAND ALP HRS

Wave 189

Wave 153

RAND ALP HRS

RAND ALP HRS

\begin{abstract}
${ }^{\mathrm{a}}$ A set of surveys, based on the Health and Retirement (HRS) 2008 surveys, are being fielded on the ALP in a continuous basis (see https://mmicdata.rand.org/alp/index.php?page=hrs). As noted on the ALP data pages, "The RAND ALP HRS compiles these data using the same methodology as the RAND HRS. The RAND HRS contains cleaned and processed Health and Retirement Study variables with consistent and intuitive naming conventions, model-based imputations and imputation flags, and spousal counterparts of most individual-level variables. To read more about the RAND HRS methodology and variable derivations please refer to the data documentation available at http://hrsonline.isr.umich.edu/modules/meta/rand/randhrsk/randhrsk.pdf." The variables used here derive largely from ALP waves 65 (HRS Section P: Expectations) and 67 (HRS Section J: Employment and Section K: Retirement).
\end{abstract}

\title{
Measures
}

\section{Demographics}

The ALP collects and updates quarterly basic demographic information about all panelists, including age, gender, marital status, employment status, household income, and other characteristics. Gender is a binary variable equal to one if male and zero if female. Marital status is designated with two binary variables, one indicating whether the person was currently married and one indicating whether that person was currently divorced. Education and wealth 
are used as indicators of socio-economic status. Education is defined categorically: less than high school, high school, some college, and college graduate or more. Wealth, which derived from the ALP HRS battery, is the net value of non-housing wealth. ${ }^{2}$ Because wealth distributions are substantially different for singles and couples, but this difference is not necessarily related to the concept of socio-economic status, we calculated wealth separately for singles and for couples. Wealth was then categorized into low, medium, and high terciles to allow for nonlinear effects, before merging data for singles and couples into a single variable. We classified age into 5-year ranges starting with the 45-49 age group, again to allow for non-linear effects.

\section{Health status}

To assess health status, we used the ALP question asking respondents, "Would you say your health is excellent, very good, good, fair, or poor?” Using a reference category of "good” health, we created a categorical variable for "better" health, comprising those responding "excellent” or "very good," and a categorical variable for "bad” health, comprising “fair” or "poor."

\section{Characterizing retirement decision making}

Because retirement decision making likely evolves over time, and because different types of data (e.g., expectations about future behavior, self-reports of past behavior) are available from different subsamples (e.g., based on whether respondents were retired at the time of assessment), we took a multi-perspective approach to considering retirement decision making among individuals approaching, recently experiencing, or past retirement.

Retirement expectations. Among those for whom retirement is in the foreseeable future (i.e., age 45 and above), we examined expectations of working full-time after age 62 and after age 65 . Such questions have been shown to be good predictors of actual retirement by these dates (Hurd, 2009). The ALP asked respondents age 45-61, “Thinking about work in general and not just your present job, what do you think the chances are that you will be working full-time after you reach age 62?” (labeled P62). It asked those under 65: “And what about the chances that you will be working full-time after you reach age 65?” (labeled P65). Responses for both questions range from zero to 100 . We considered these variables both linearly (i.e., as-is) and in a binary form to indicate expectations or plans for early retirement. Based on examination of the response distribution, our binary form defined early expected retirement for those who said their probability of working full-time after age 62 was no more than $20 \%$, (i.e., P62 $\leq 20 \%$ ). Similarly, we identified expected late retirement for those who said their probability of working full-time after age 65 was at least $80 \%$ (i.e., P65 $\geq 80 \%$ ).

\footnotetext{
${ }^{2}$ We calculated the net value of non-housing wealth as the sum of net value of real estate (excluding primary residence), net value of vehicles, net value of business, net value of IRA and Keogh accounts, net value of stocks, mutual funds, and investment trusts, value of checking, savings, or money market accounts, value of CD, government savings bonds, and T-bills, net value of bonds and bond funds, and net value of all other savings minus debt.
} 
Coherence of retirement expectations. Because these two expectations have a logical relationship (i.e., the likelihood of working full-time after age 65 cannot be more than the likelihood of working full-time after age 62), we also computed an indicator of whether the difference between these two expectations was positive, zero, or negative. A positive number (P65 < P62) is entirely coherent. Zero (P65 = P62) is technically coherent but may also indicate less-refined thinking about the subjective expectations. Because of this, we chose to separate these responses from the entirely coherent. However, because we cannot say that they are technically wrong, we label these simply as equal likelihood. A negative number (P65 > P62) is a logical impossibility, and so is labeled incoherent. Presumably, those with less coherent retirement expectations may also engage in less coherent retirement planning. ${ }^{3}$

Reported age of retirement. For those already retired, we considered two sources for reports on actual retirement age. The first, from the ALP HRS, asked respondents whether they considered themselves completely retired, partly retired, or not retired at all. Respondents indicating that they were currently retired (either completely or partly) were asked the year and month of their retirement. We compared this to their reported birth year and month to compute retirement age. The second source for retirement age comes from quarterly demographic surveys that update the information on respondents' job status every three months, including whether the respondent identifies as retired. Because this survey is collected quarterly, the time series of responses allows identification of transitions from employed to retired.

Unfortunately, there are two challenges to using the demographic surveys to identifying the timing of retirement. First, many individuals enter the panel as retired, so their retirement ages are left-censored. Second, individuals may consider themselves retired at a given point and time but later decide to reenter the work force. Hence, retirement age based on even the latest transition may systematically underestimate retirement age for a segment of the sample. Because of these concerns, we chose the HRS self-report as the primary indicator of retirement age. For those missing this variable, we supplemented with data from the quarterly demographic surveys, excluding those who entered the panel as retired. When using the demographic survey time series, we considered a person to be retired if that person indicated their employment status as retired in at least two consecutive quarters (so as to avoid transient reporting unreliability). ${ }^{4}$ As above, our analysis excludes respondents who reported having retired before age 45 .

As we did for expectations, we created binary variables based on retirement age, to indicate either early or late retirement. We considered a person to have retired early if doing so before age

\footnotetext{
${ }^{3}$ Looking at the rate of incoherence, reported below, supports the 45 -and-older age restriction. The rate of incoherence in retirement expectations (i.e., such that P65 < P62) steadily decreases with age through the 60s (at which point retirement expectations are no longer assessed). This is likely due to resolved uncertainty.

${ }^{4}$ We compared two different operationalizations for this variable: one that defined retirement based on such a report in one quarterly demographic survey, and a second that required such a report in two consecutive quarterly surveys. The results were qualitatively the same, largely because these two versions only differed for six respondents. Because of this, we were confident that even more stringent requirements (e.g., three consecutive months) would provide vanishing marginal benefit.
} 
62 (i.e., before becoming age-eligible to receive Social Security benefits). We considered a person to have retired late if doing so after reaching the full retirement age (FRA) for receiving full social security benefits. We restricted our analysis of retirement before age 62 to respondents at least 62 years of age and our analysis of retirement after the FRA to respondents who retired after reaching it (and which depended on their cohort of birth, see Appendix A).

Whether retirement was timed as expected. In the new survey fielded just for this project, panelists who retired in the past five years were asked: "Was this about when you planned or expected to retire or was it earlier or later?" Response options included "I retired earlier than I had expected," "I retired about when I had expected," and "I retired later than I had expected."

\section{Cognitive ability}

One of the strengths of the ALP is the availability of in-depth characterizations of cognitive ability. Using the ALP, researchers have been developing a set of computer-adaptive tests of cognitive ability, based on nationally normed but unpublished items from several tests fielded as part of the Woodcock-Johnson III (WJ-III) battery of cognitive ability tests (Woodcock, McGrew, \& Mather, 2001). Each test provides a W-score, normed to the population. Higher W scores indicate greater cognitive ability. The tests are designed to be centered at 500 and have a standard deviation of about 10. Participants in the ALP average more than 500, indicating they have greater-than-average cognitive ability. That said, substantial variability exists in the ALP data, which we leverage in the analyses below.

Number series. The ALP includes a 15-item instrument applied in a Block Adaptive Testing (BAT) format. The task is based on the Woodcock-Johnson III (WJ-III) Number Series test. In this task, participants are given a sequence of numbers with a blank somewhere in the sequence. They are to figure out the pattern of numbers present and provide the missing value. For example, they may see, "Please complete the series of numbers: $3,5,7$, _.." The test is part of the math reasoning block, indicated as a quantitative concept task in the WJ-III framework, and can be considered a test of fluid cognitive ability. For the BAT design, respondents first received three items of varying difficulty. Based on their score for these items, they were routed to one of four other three-item sets, of increasing difficulty, based on the number they got correct in the first set.

Picture vocabulary. In this task participants are shown a picture and asked to type the name of the depicted object in a free-text box. For example, they may be shown a picture of a goat and told, "Please type in the name of the main object in the picture below." As with the Number Series test, respondents receive six of 15 items in a BAT format. The Picture Vocabulary test measures crystallized cognitive abilities.

Verbal analogies. In this task participants are shown a text-based analogy, with the final element missing, and asked to type the name of the depicted object in a free-text box. For example, "Please complete the analogy. Hot is to Cold, as Full is to ." As with the Number 
Series test, respondents receive six of 15 items in a BAT format. The Verbal Analogies test measures both fluid and crystallized cognitive abilities.

Number series, verbal analogies, and picture vocabulary tests were all conducted in a single survey session.

\section{Financial literacy}

A subset of nine ALP items, developed from the scale designed by Lusardi and Mitchell (2007), addresses numeracy and knowledge regarding interest, inflation, time value of money, stocks and bonds, and diversification. For example, the first question asks, "Suppose you had $\$ 100$ in a savings account and the interest rate was $2 \%$ per year. After 5 years, how much do you think you would have in the account if you left the money to grow?” Response options are “More than \$102," “Exactly \$102,” “Less than \$102,” and “I don't know.” The financial literacy score is an index derived from a Principal Components Analysis of whether or not the respondent gave a correct answer to each question. The first principal component (used here) explains about $40 \%$ of the total variance.

\section{Longevity and social security expectations}

Respondents younger than age 65 were asked "What is the percent chance that you will live to be 75 or more?” To take into account differences in longevity expectations associated with age, we divided the self-reported probability of living to age 75 by the respondent-specific implied probability of living to be 75 from the Vital Statistics life tables, taking into account the respondent's age and gender. Because the question about longevity expectations is asked only to respondents under age 65, this information is not available for most retirees in our sample. For this reason, we chose to exclude longevity expectations from our analysis of the predictors of actual retirement age, but to include it in the analysis of retirement expectations.

All respondents were asked, "Thinking of the Social Security program in general and not just your own Social Security benefits: On a scale from 0 to 100, what is the percent chance that Congress will change Social Security sometime in the next 10 years, so that it becomes less generous than now?” For each, responses range from 0 to 100.

\section{Future time perspective}

Building on Cate and John's (2007) critique of Carstensen and Lang's (1996) measure of future time perspective, the ALP included a revised measure of time perspective that confirmed Cate and John's two-factor structure: focus on opportunities (e.g., "Many opportunities await me in the future") and focus on limitations (e.g., "I have the sense that time is running out"). Indices for each were operationalized as the sum of the items related primarily to opportunities (7 items; Cronbach $\alpha=.90$ ) and limitations (5 items; Cronbach $\alpha=.76$ ). 


\section{Maximizing tendencies}

We used Schwartz et al.’s (2002) 13-item maximizing versus satisficing scale. This generated both an overall metric of the tendency to maximize, as well as three subscales, based on analyses by Nenkov et al. (2008). The first subscale includes three items that assess the degree to which the respondents sees herself as having high standards (e.g., "No matter what I do, I have the highest standards for myself;" Cronbach $\alpha=.65$ ). The second includes six items assessing the extent to which an individual engages in continual search for alternatives (e.g., "When I watch TV, I channel surf, often scanning through the available options even while attempting to watch one program;" Cronbach $\alpha=.63$ ). The third includes four items that express experiencing decision difficulty (e.g., "Renting videos is really difficult. I'm always struggling to pick the best one;" Cronbach $\alpha=.61$ ). Indices for each component are computed by taking the sum of the component items.

\section{Sample Size}

There were 1,079 observations with non-missing age of retirement, 756 of whom were 62 or older and 532 of whom had reached their full retirement age. ${ }^{5}$ The probability of working fulltime after 62 was available for 1,864 respondents; the probability of working full-time after 65 was available for 2,056.

Some respondents had missing values for one of the following: cognitive ability (16\% of the sample), future time perspective (19\%), longevity expectations (21\%), wealth (2\%), and Social Security expectations (0.3\%). Forty-four percent of the sample had a missing value for at least one of those variables. We kept these respondents in the sample and replaced their missing values with a zero. We then used indicator variables to identify those respondents. Inclusion of the indictors allows us to examine whether those values were missing at random or not (in the latter case, the indicators would themselves be significant predictors). Retaining or dropping these respondents yields similar results.

Of the 402 ALP panelists invited to participate in the new survey because they were within five years of having retired (based on prior survey responses), 337 completed the survey, for an $84 \%$ response rate. Of these, 308 (91\%) confirmed that they were completely or partly retired, and 303 responded to the question asking whether that retirement was earlier than expected, as expected, or later than expected, as well as having a complete set of analytic variables. The remaining 29 individuals indicated that they were "not at all” retired, highlighting that people may move into and out of retirement.

\footnotetext{
${ }^{5}$ Seven observations missing demographics and two observations missing health status were dropped from the data.

${ }^{6}$ We dropped from these analyses three observations for whom longevity expectations was missing.

${ }^{7}$ Information on planned retirement (i.e., P62, P65) and on actual retirement age were available for some respondents (411 for P65 and 285 for P62) who answered questions about their retirement plans in the ALP HRS and were later observed transitioning into retirement in the quarterly demographic surveys.
} 


\section{Analysis Plan}

We used a combination of linear and ordered probit regressions to examine whether cognitive ability, financial literacy, future time perspective, maximizing tendencies, and longevity and Social Security expectations predict our dependent variables. To mirror the developmental trajectory of retirement decision making, we first consider dependent variables based on retirement expectations (which are determined pre-retirement), and then follow with dependent variables based on retirement age (which can only be judged post-retirement). Some specifications controlled for demographics, wealth and health. We first conducted binary regressions to document basic relationships among pairs of variables. We then conducted multivariate regressions sequentially (a) adding health status, wealth and all demographics except age, (b) adding all other predictors except age, and (c) adding age. We added age last because of its strong relationships to several of the predictors of interest, including cognitive ability, future time perspective, and longevity expectations. Because the financial literacy and maximizing tendencies variables contained much more missing data, we examined these predictors in separate regressions, containing only the covariates (and not imputing missing data). Section 3 presents the results related specifically to the focal hypotheses. Appendix B includes full regression results, with all covariates. 


\section{Results}

\section{Sample description}

Table 3.1 presents descriptive demographic statistics for the full analytic sample, as well as the pre-retirement subsample (used for expectations for retirement), post-retirement subsample (used for retirement age), and recent-retirement subsample (used for the new survey).

The characteristics of the full sample and the subsamples are largely similar, although there are some expected differences. The pre-retirement subsample, not surprisingly, is younger than the retired subsamples. The pre-retirement subsample is a bit more likely to be married, has a slightly higher level of education, and reports somewhat better health than the post-retirement subsample. The recently-retired subsample more closely resembles the pre-retirement subsample on these characteristics. The pre-retirement subsample includes a small number of individuals who at later ages have still not retired. The post-retirement subsample, by contrast, has a substantial number of individuals who report being retired at relatively early ages. 
Table 3.1. Descriptive demographic statistics for the full analytic sample and specific subsamples.

\begin{tabular}{|c|c|c|c|c|}
\hline Demographic Variable & $\begin{array}{l}\text { Full Analytic } \\
\text { Sample }\end{array}$ & $\begin{array}{c}\text { Pre- } \\
\text { retirement } \\
\text { Subsample }\end{array}$ & $\begin{array}{c}\text { Post- } \\
\text { retirement } \\
\text { Subsample }\end{array}$ & $\begin{array}{c}\text { Recent- } \\
\text { retirement } \\
\text { Subsample }\end{array}$ \\
\hline \multicolumn{5}{|l|}{$\overline{\text { Age }}$} \\
\hline$\% 45-49$ & 18.8 & 24.2 & 1.5 & 2.3 \\
\hline$\% 50-54$ & 21.6 & 27.5 & 5.3 & 7.6 \\
\hline$\% 55-59$ & 21.1 & 26.2 & 14.9 & 20.5 \\
\hline$\% 60-64$ & 16.2 & 18.3 & 23.6 & 38.6 \\
\hline$\% 65-69$ & 10.2 & 2.8 & 24.3 & 21.5 \\
\hline$\% 70$ or above ${ }^{a}$ & 12.1 & 1.0 & 30.4 & 9.6 \\
\hline$\%$ male & 44.4 & 43.2 & 47.5 & 41.9 \\
\hline \multicolumn{5}{|l|}{ Marital status } \\
\hline$\%$ married & 61.5 & 63.0 & 60.0 & 63.7 \\
\hline$\%$ divorced & 17.8 & 18.1 & 17.0 & 19.8 \\
\hline$\%$ other $^{\mathrm{a}}$ & 20.7 & 18.9 & 23.0 & 16.7 \\
\hline \multicolumn{5}{|l|}{ Education } \\
\hline$\%$ less than high school ${ }^{a}$ & 7.8 & 7.3 & 8.2 & 6.7 \\
\hline$\%$ high school & 20.3 & 18.6 & 21.9 & 21.1 \\
\hline$\%$ some college & 32.2 & 33.2 & 30.0 & 30.7 \\
\hline$\%$ college graduate & 39.7 & 40.9 & 39.9 & 41.3 \\
\hline \multicolumn{5}{|l|}{ Health } \\
\hline$\%$ excellent or very good & 54.0 & 56.3 & 50.3 & 52.1 \\
\hline$\% \operatorname{good}^{\mathrm{a}}$ & 32.5 & 31.8 & 33.2 & 33.7 \\
\hline$\%$ fair or poor & 13.5 & 11.9 & 16.5 & 14.2 \\
\hline
\end{tabular}




\section{Retirement expectations}

We first consider retirement expectations for those not yet retired. Among ALP respondents 45 to 61 years of age who had not yet retired, 1,864 responded to the question on whether they planned to work full-time after age 62, and among those age 45 to 64 and not retired, 2,056 responded to the question regarding whether they planned to work full-time after age 65 (1,863 responded to both questions). Table 3.2 provides descriptive statistics for each variable.

On average, respondents reported a 60.2\% chance of working full-time after age 62 (median $=70 \%$ ) and a $42.0 \%$ chance of working full-time after age 65 (median $=40 \%$ ). There was substantial variation in both reports, with respondents using the full probability range. As seen in past research using subjective probability judgments (e.g., Hurd, McFadden, \& Gan, 1998; Lillard \& Willis, 2001), there were substantial numbers of respondents saying $0 \%$ and $100 \%$, representing subjective certainty, as well as at 50\%, which often represents responses of epistemic uncertainty (i.e., “I don’t know;” Bruine de Bruin et al., 2000). That said, respondents on the ALP are quite used to providing subjective probability judgments, and have received substantial instruction in this response scale, so the proportion of focal-judgment responses is lower than seen in other samples.

Table 3.2. Description of subjective-probability retirement expectations.

\section{Probability of Working Full- Probability of Working Full- time After Age 62 time After Age 65}

\begin{tabular}{lcc}
\hline Mean & 60.2 & 42.0 \\
$\begin{array}{l}\text { Standard Deviation } \\
\text { Percentile }\end{array}$ & 36.0 & 33.8 \\
$0^{\text {th }}$ & 0 & 0 \\
$25^{\text {th }}$ & 25 & 10 \\
$50^{\text {th }}$ & 70 & 40 \\
$75^{\text {th }}$ & 99 & 70 \\
$100^{\text {th }}$ & 100 & 100 \\
Focal Judgments & & \\
$\%$ "0" & 9.7 & 16.9 \\
$\%$ "50" & 15.7 & 15.4 \\
$\%$ "100" & 23.5 & 7.0
\end{tabular}


Table 3.3 presents regressions predicting the expectation of working full-time after age 62 and after age 65. For each, we first present bivariate results, to show the simple relationships between each predictor and each dependent variable, and then the multivariate regressions.

Among those before retirement age and not yet retired, our hypothesis (H1) on cognitive abilities and retirement expectations finds support. Those scoring higher in cognitive ability, and in particular on the picture vocabulary test of crystallized intelligence, report a greater probability of working full-time after age 62 or age 65. In the multivariate analyses, an increase in one standard deviation on the picture vocabulary scale predicts a 2.5 percentage point increase in the probability of plans to work after age 62 and a 2.1 percentage point increase in plans to work after age $65 .{ }^{8}$ We found mixed results regarding our hypothesis (H5) about future time perspective. In the bivariate regressions, a greater focus on opportunities was associated with expectation of working later in life, but this effect was not significant after controlling for health and demographics. A focus on limitations did have a significant effect on plans to work later in life in both the bivariate and multivariate equations. Specifically, a one standard deviation increase in focus on limitations predicts a 1.9 percentage point increase in expectation of working full-time after age 65 .

We found that greater longevity expectation (normalized to life tables) was a strong and consistent predictor of working later in life, supporting our hypothesis (H3). Specifically, in the multivariate model, we found that a one standard deviation increase in the perceived longevity ratio (self-reported probability of living to age 75 divided by the implied probability from the Vital Statistics life table) led to a 6.0 percentage point increase in expected probability of working full-time past age 62 and a 6.5 percentage point increase in expected probability of working past age 65.

Contrary to our hypothesis (H4), we found that expectations of Social Security reform that would reduce benefits were positively, not negatively, related to expectations of retiring later. Specifically, our multivariate model found that a one standard deviation increase in expectation of reduced benefits predicted a 2.9 percentage point increase in estimated probability of retiring after age 62 and a 3.1 percentage increase in estimated probability of retiring after age 65 . These results are consistent with the alternative hypothesis that the uncertainty about Social Security may lead individuals to anticipate working longer to compensate for the reduction in the generosity of the benefits.

\footnotetext{
${ }^{8}$ Cognitive ability was generally not missing at random, and in particular for picture vocabulary. This may be due to the fact that the cognitive ability tests were fielded relatively recently, and many of those missing the tests may be those who were in the panel in earlier years but are no longer participating. Furthermore, based on mean scores for the three cognitive ability tests, the expected difference between missing and non-missing respondents was small. For example, it was less than three percentage points for P62 (59.7 for non-missing and 62.0 for missing). Parallel analyses dropping all those with missing data gave qualitatively similar results.
} 
Table 3.3. Bivariate and multivariate regression analyses of expectation for working full-time after age 62 and age 65.

\begin{tabular}{|c|c|c|c|c|}
\hline \multirow[b]{2}{*}{ Predictor } & \multicolumn{2}{|c|}{$\begin{array}{c}\text { Expectation of Working Full- } \\
\text { time after age } 62\end{array}$} & \multicolumn{2}{|c|}{$\begin{array}{l}\text { Expectation of Working Full- } \\
\text { time after age } 65\end{array}$} \\
\hline & $\begin{array}{c}\text { Bivariate } \\
\text { Regressions }\end{array}$ & $\begin{array}{l}\text { Multivariate } \\
\text { Regression }\end{array}$ & $\begin{array}{c}\text { Bivariate } \\
\text { Regressions }\end{array}$ & $\begin{array}{l}\text { Multivariate } \\
\text { Regression }\end{array}$ \\
\hline \multicolumn{5}{|l|}{ Cognitive ability } \\
\hline \multirow[t]{2}{*}{ Number series } & 0.089 & -0.005 & 0.074 & 0.011 \\
\hline & $(0.038)^{\star \star}$ & $(0.046)$ & $(0.034)^{\star \star}$ & $(0.041)$ \\
\hline \multirow[t]{2}{*}{ Picture vocabulary } & 0.127 & 0.106 & 0.090 & 0.087 \\
\hline & $(0.038)^{\star \star \star}$ & $(0.042)^{\star \star}$ & $(0.033)^{\star \star \star}$ & $(0.037)^{\star \star}$ \\
\hline \multirow[t]{2}{*}{ Verbal analogies } & 0.080 & 0.009 & 0.057 & 0.011 \\
\hline & $(0.039)^{\star \star}$ & $(0.047)$ & $(0.035)$ & $(0.042)$ \\
\hline \multicolumn{5}{|l|}{ Future time perspective } \\
\hline \multirow[t]{2}{*}{ Focus on opportunities } & 1.704 & 0.634 & 1.876 & 0.717 \\
\hline & $(0.776)^{\star \star}$ & $(0.756)$ & $(0.688)^{\star \star \star}$ & $(0.668)$ \\
\hline \multirow[t]{2}{*}{ Focus on limitations } & 0.467 & 0.702 & 1.312 & 1.578 \\
\hline & $(0.840)$ & $(0.821)$ & $(0.737)^{\star}$ & $(0.708)^{\star \star}$ \\
\hline \multicolumn{5}{|l|}{ Expectations } \\
\hline \multirow[t]{2}{*}{ Longevity (ratio) } & 20.066 & 17.044 & 19.554 & 18.418 \\
\hline & $(2.317)^{\star \star \star}$ & $(2.416)^{\star \star \star}$ & $(2.034)^{\star \star \star}$ & $(2.142)^{\star \star \star}$ \\
\hline \multirow[t]{2}{*}{ Social security } & 0.111 & 0.107 & 0.116 & 0.114 \\
\hline & $(0.032)^{\star \star \star}$ & $(0.032)^{\star \star \star}$ & $(0.028)^{\star \star \star}$ & $(0.027)^{\star \star \star}$ \\
\hline
\end{tabular}

* Two-sided $\mathrm{p}$-value $<.10 ;$ ** $\mathrm{p}<.05 ;$ *** $\mathrm{p}<.01$

NOTE: Numbers reported are regression coefficients, with standard errors in parentheses. Within bivariate regressions, each predictor was entered as a single variable, coupled with the missingness indicator (not shown). Note that both future time perspective variables were entered together. Other control variables in the multivariate regressions include gender, marital status, education, wealth, health status, and age. Full regression results are presented in Appendix B. Results are qualitatively similar either excluding or imputing missing values.

Greater financial literacy predicted greater probability of working full-time after age 62 in a binary regression ( $\mathrm{b}=1.11, \mathrm{p}<.10)$, as we hypothesized $(\mathrm{H} 1)$, but was not significant in the multivariate equation (results in Appendix B), nor was it significant for the equations on probability of working after age 65 . We found mixed results regarding our hypothesis on 
maximizing behavior and probability of retirement. Specifically, a greater tendency to search continually predicted a greater expectation to work full-time after age 62 ( $\mathrm{b}=1.92, \mathrm{p}<.10$ ), as did experiencing less decision difficulty $(b=-1.85, \mathrm{p}<.10)$. Both these effects, however, were not significant in the multivariate equations (results in Appendix B). The self-reported tendency to have high standards was associated with a lower perceived probability of working full-time after age $62(\mathrm{~b}=-1.82, \mathrm{p}<.10)$ or $65(\mathrm{~b}=-2.05, \mathrm{p}<.05)$ in the multivariate equations. A one standard deviation increase in the high standards index was associated with a 1.9 percentage point decrease in the probability of working past age 62 and a 2.2 percentage point decrease in the probability of working past age 65 .

\section{Coherence of retirement expectations}

We next examine coherence of retirement expectations among those 45 to 61 years of age and not yet retired. Logically, respondents in this population should give a probability of working full-time after age 65 that is less than or equal to that of working full-time after age 62. Those 1,220 ALP respondents who gave a probability of working past age 65 (P65) that is less than or equal to that of working past age 62 (P62) we consider to have fully coherent expectations. Those 91 respondents for whom P62 is greater than age 65 we consider to have incoherent expectations. Those 552 respondents for whom P62 equals P65 are technically coherent, but a strict equality is unlikely and may reflect less refined probabilistic thinking.

Our main hypothesis about coherence (H2) stated that greater cognitive ability will be associated with greater coherence in retirement expectations. We conducted one-way ANOVA analyses on this three-way distinction of coherence, with each of our cognitive ability scores as dependent variables. The results are qualitatively the same and significant (all model ps $<.01$ ) for all cognitive ability scores. Consistent with $\mathrm{H} 2$, those who gave incoherent responses showed substantially lower cognitive ability than did those who gave coherent responses. Those who gave equal responses to P62 and P65 did, in fact, have somewhat lower cognitive ability scores than those giving fully coherent responses. This supports the assertion that equal responses, while are technically coherent, may reflect less refined probabilistic thinking. Figure 3.1 shows these results for each type of cognitive test by coherence in retirement expectations. 
Figure 3.1. Cognitive ability is lower for those with more incoherent retirement expectations.

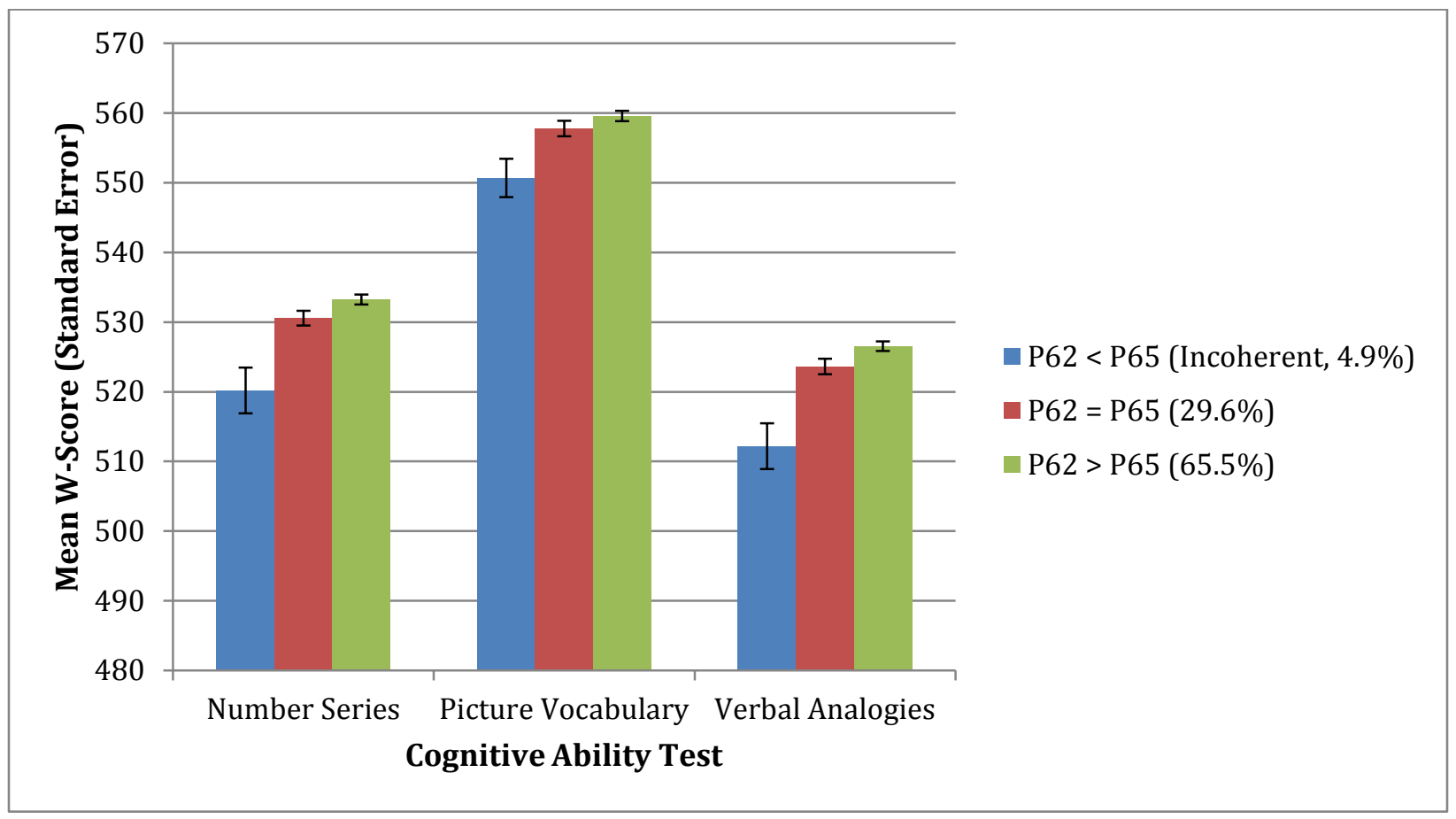

We found precisely the same result on financial literacy: those with incoherent expectations had the worst financial literacy scores (mean $=-.83$ ), those with equal expectations had the second-worst scores (mean $=.12$ ), and those with fully coherent expectations had the best (mean $=.43)$ scores.

In other words, respondents with greater cognitive ability think about (or at least report) retirement expectations more coherently (or perhaps better understand the ALP response scale). Presumably this could affect the reasonableness of retirement planning. These results are consistent with prior research on decision-making competence, which includes a task that assesses individual differences in the coherence of expectations (Parker \& Fischhoff, 2005; Bruine de Bruin et al., 2007).

\section{Expectation of retiring early and expectation of retiring late}

Recall that we considered P62 and P65 variables both linearly (i.e., as-is) and in binary form to indicate expectations or plans for early or late retirement. We defined expected early retirement as reporting a subjective probability of working full-time after age 62 no greater than $20 \%$, i.e., P62 $\leq 20 \%$. Similarly, we defined expected late retirement as reporting a subjective probability of working full-time after age 65 of at least $80 \%$, i.e., P65 $\geq 80 \%$. By these definitions, $18.9 \%$ of respondents reported they planned to retire early, and $15.0 \%$ of respondents reported they planned to retire late. Table 3.4 presents regressions predicting these two binary variables. 
Table 3.4. Bivariate and multivariate regression analyses of expectation for retiring early (P62 $\leq$ $20 \%$ ) and for retiring late ( $P 65 \geq 80 \%$ ).

\begin{tabular}{|c|c|c|c|c|}
\hline \multirow[b]{2}{*}{ Predictor } & \multicolumn{2}{|c|}{$\begin{array}{l}\text { Expectation of Retiring Early } \\
\qquad(\mathrm{P} 62 \leq 20 \%)\end{array}$} & \multicolumn{2}{|c|}{$\begin{array}{l}\text { Expectation of Retiring Late } \\
\qquad(\mathrm{P} 65 \geq 80 \%)\end{array}$} \\
\hline & $\begin{array}{c}\text { Bivariate } \\
\text { Regressions }\end{array}$ & $\begin{array}{l}\text { Multivariate } \\
\text { Regression }\end{array}$ & $\begin{array}{c}\text { Bivariate } \\
\text { Regressions }\end{array}$ & $\begin{array}{l}\text { Multivariate } \\
\text { Regression }\end{array}$ \\
\hline \multicolumn{5}{|l|}{ Cognitive ability } \\
\hline \multirow[t]{2}{*}{ Number series } & -0.000157 & 0.000559 & 0.000618 & -0.000066 \\
\hline & $(0.000)$ & $(0.000)$ & $(0.000)^{\star}$ & $(0.000)$ \\
\hline \multirow[t]{2}{*}{ Picture vocabulary } & -0.000543 & -0.000506 & 0.001387 & 0.001339 \\
\hline & $(0.000)$ & $(0.000)$ & $(0.000)^{\star \star \star}$ & $(0.000)^{\star \star \star}$ \\
\hline \multirow[t]{2}{*}{ Verbal analogies } & -0.000361 & -0.000234 & 0.000454 & -0.000239 \\
\hline & $(0.000)$ & $(0.001)$ & $(0.000)$ & $(0.000)$ \\
\hline \multicolumn{5}{|l|}{ Future time perspective } \\
\hline \multirow[t]{2}{*}{ Focus on opportunities } & -0.021046 & -0.008779 & 0.008101 & 0.002305 \\
\hline & $(0.008)^{\star \star}$ & $(0.008)$ & $(0.008)$ & $(0.008)$ \\
\hline \multirow[t]{2}{*}{ Focus on limitations } & -0.007508 & -0.014091 & 0.014450 & 0.013322 \\
\hline & $(0.009)$ & $(0.009)$ & $(0.008)^{\star}$ & $(0.008)^{\star}$ \\
\hline \multicolumn{5}{|l|}{ Expectations } \\
\hline \multirow[t]{2}{*}{ Longevity (ratio) } & -0.138023 & -0.114282 & 0.155107 & 0.141551 \\
\hline & $(0.028)^{\star \star \star}$ & $(0.028)^{\star \star \star}$ & $(0.022)^{\star \star \star}$ & $(0.023)^{\star \star \star}$ \\
\hline \multirow[t]{2}{*}{ Social security } & -0.000338 & -0.000312 & 0.001061 & 0.001092 \\
\hline & $(0.000)$ & $(0.000)$ & $(0.000)^{\star \star \star}$ & $(0.000)^{\star \star \star}$ \\
\hline
\end{tabular}

* Two-sided $p$-value $<.10 ; *$ * $p<.05 ;{ }^{* \star *} p<.01$

NOTE: Numbers reported are regression coefficients, with standard errors in parentheses. Within bivariate regressions, each predictor was entered as a single variable, coupled with the missingness indicator (not shown). Note that both future time perspective variables were entered together. Other control variables in the multivariate regressions include gender, marital status, education, wealth, health status, and age. Full regression results are presented in Appendix B. Results are qualitatively similar either excluding or imputing missing values.

Contrary to our hypothesis (H1), cognitive ability had no effect on plans to retire early. Nevertheless, Picture vocabulary score strongly predicted plans to retire late, both in bivariate 
and multivariate equations. That is, those with higher levels of crystallized cognitive ability were more likely to expect to continue working full-time (and hence retire) past age $65 .{ }^{9}$

Also contrary to our hypothesis (H5), future time perspective had little effect in expectations of early retirement, at least in our multivariate analysis. A focus on limitations, however, was a modest but significant predictor of late retirement expectations, even after controlling for other variables. Specifically, a one standard deviation increase in a focus on limitations led to a 1.6 percentage point increase in expecting a late retirement.

Greater longevity expectation, normalized for life tables, was a large and consistent predictor of lower expectations to retire early and higher expectations to retire late, supporting our hypothesis (H3). Specifically, a one standard deviation increase in longevity ratio predicted a 3.9 percentage point decrease in the expected likelihood of early retirement and a 5.0 percentage point increase in the expected likelihood of late retirement.

Greater expectation of social security changes was a predictor only of late retirement expectations. This contradicts our hypothesis (H4) that expectation of reform diminishing Social Security payment will lead to earlier retirement to lock in benefits. ${ }^{10}$ In fact, quite the opposite was the case, and may support a counter-hypothesis that those anticipating reform may expect to have to remain in the workforce longer to make up for lost benefits. Financial literacy was not a significant predictor of either early or late retirement, but maximizing tendencies were. Contrary to our hypothesis (H5), our multivariate models showed that having high-standards predicted plans to retire early ( $\mathrm{b}=.03, \mathrm{p}<.01$ ), as did engaging in less continual search $(\mathrm{b}=.03, \mathrm{p}<.05$ ). Having high standards also led to a marginally lower expected likelihood of late retirement $(b=-$ $.02, \mathrm{p}<.10)$.

\section{Retirement age}

As Table 3.5 indicates, reported retirement ages vary widely, among those reporting being retired.

\footnotetext{
${ }^{9}$ Picture Vocabulary was not missing at random for late retirement expectations, but was for early retirement expectations. This may be due to the fact that the cognitive ability tests were fielded relatively recently, and many of those missing the tests may be those who were in the panel in earlier years but are no longer participating. Furthermore, based on mean scores for the three cognitive ability tests, the expected difference between missing and non-missing respondents was less than three percentage points for P62 (56.5 for non-missing vs. 57.8 for missing). Results were qualitatively similar excluding all those with missing data.

${ }^{10}$ Social Security expectations were not missing at random, but were missing for only 16 observations.
} 
Table 3.5. Description of reported retirement age.

\begin{tabular}{lc}
\hline & Retirement Age \\
\hline Mean & 59.3 \\
Standard Deviation & 6.3 \\
Percentile & \\
$0^{\text {th }}$ & 45.0 \\
$25^{\text {th }}$ & 55.0 \\
$50^{\text {th }}$ & 60.25 \\
$75^{\text {th }}$ & 63.5 \\
$100^{\text {th }}$ & 89.5 \\
\hline
\end{tabular}

Among ALP respondents who are already retired, the mean retirement age was 59.3 and the median 60.25, with a range from 45 to 89.5. We note that reported retirement ages may be rightcensored. Some individuals who consider themselves retired may reenter the workforce at a later date. Hence, in a self-report database like the ALP, reported retirement age may not be the age of "last" retirement. That said, we will focus largely on relative differences in retirement age rather than absolute ages. Table 3.6 presents bivariate and multivariate regression analyses predicting reported retirement age.

While we hypothesized that greater cognitive abilities would lead to later retirement (H1), we find that, among those already retired, there is virtually no relation between cognitive abilities and retirement age. For all three cognitive ability tests, the cognitive ability coefficients are not statistically significant.

We also hypothesized that focusing on opportunities, or seeing a more expansive future in one's remaining years, would lead to later retirement (H5). This hypothesis does not appear to be supported among those already retired. Rather, a focus on opportunities led to a lower retirement age for these respondents, both in the bivariate and multivariate analyses, and in both cases by a statistically significant amount. We find a one standard deviation increase in our measure for focus on opportunities reduced reported retirement age by 0.47 years, controlling for all other covariates. By contrast, a focus on limitations has no statistically significant effect on retirement age for those already retired. ${ }^{11}$ Similarly, contrary to our hypothesis (H4), we find expectations

\footnotetext{
11 There was a modest effect $(\mathrm{b}=-2.32, \mathrm{p}<.10)$ for the future time perspective missingness indicator, suggesting that the focus on opportunities and focus on limitations variables may not be missing at random. This may not be surprising, given that the future time perspective assessment was conducted relatively recently, and hence is missing for those who left the panel in earlier years. That said, comparing missing to non-missing individuals, the expected retirement age is 59.0 for those missing future time perspective and 59.8 for those with the variables.
} 
of future Social Security changes were not associated with age at retirement. As noted in Section 1, however, such expectations may more closely tie to anticipation of retirement (i.e., preretirement thinking, such as retirement expectations) than to age of actual retirement.

Table 3.6. Bivariate and multivariate regression analyses of reported retirement age.

\begin{tabular}{lll}
\hline & \multicolumn{2}{c}{ Retirement Age } \\
\cline { 2 - 3 } \multicolumn{1}{c}{ Predictor } & $\begin{array}{c}\text { Bivariate } \\
\text { Regressions }\end{array}$ & $\begin{array}{l}\text { Multivariate } \\
\text { Regression }\end{array}$ \\
\hline Cognitive ability & & \\
Number series & 0.011 & 0.013 \\
Picture vocabulary & $(0.009)$ & $(0.009)$ \\
Verbal analogies & 0.007 & -0.011 \\
& $(0.010)$ & $(0.008)$ \\
& 0.004 & -0.003 \\
& $(0.010)$ & $(0.009)$
\end{tabular}

Future time perspective

Focus on opportunities

$-0.778 \quad-0.248$

$(0.176)^{\star \star \star}$

$(0.146)^{\star}$

Focus on limitations

0.162

$-0.085$

(0.195)

(0.159)

Expectations

Social security

$-0.005$

0.003

(0.007)

$(0.005)$

\begin{abstract}
* Two-sided p-value $<.10 ;{ }^{* *} \mathrm{p}<.05 ;{ }^{\star \star *} \mathrm{p}<.01$.
NOTE: Numbers reported are regression coefficients, with standard errors in parentheses. Within bivariate regressions, each predictor was entered as a single variable, coupled with the missingness indicator (not shown). Note that both future time perspective variables were entered together. Other control variables in the multivariate regressions include gender, marital status, education, wealth, health status, and age. Full regression results are presented in Appendix B. Results are qualitatively similar either excluding or imputing missing values.
\end{abstract}

Among those already retired, we observed no relationship between financial literacy and retirement age, mirroring the results for cognitive ability. Similarly, while we hypothesized 
maximizing behavior will lead to later retirement (H6), we did not consistently find this in our data on age at retirement. Rather, among the maximizing subscales, a lower general tendency to search continually for better alternatives predicted an older reported retirement age $(b=-.63, p<$ .01 ), as did self-reports of a tendency to experience decision difficulty $(b=.36, p<.10)$. Both of these effects were similar after controlling for most demographics, but became non-significant after controlling for age. Similarly, the self-reported tendency to have high standards, while being a non-significant predictor of retirement age in bivariate analyses, was a significant predictor in the multivariate analyses $(\mathrm{b}=-.33, \mathrm{p}<.10)$. A one standard deviation increase in the high standards index (1.11) was associated with a decrease in reported retirement age of .36 years. See Appendix B for summary of the full results.

\section{Early and late retirement}

We next consider results for binary variables indicating whether a retired person had an early or late retirement. An early retiree is one who retired before age 62, i.e., before becoming ageeligible for Social Security benefits. A later retiree is one who retired after reaching full retirement age (FRA) for social security benefits. We restrict our analysis of early retirement to respondents at least 62 years of age and of late retirement to respondents who had reached full retirement age, which varies by cohort of birth (see Appendix A).

Overall, 42.9\% ( $\mathrm{n}=756)$ reported retiring before age 62, and 29.3\% ( $\mathrm{n}=532)$ reported retiring after reaching FRA. Table 3.7 presents the bivariate and multivariate regression analyses predicting these two variables.

We hypothesized that greater cognitive abilities would be associated with later retirement (H1), but find mixed effects on the indicator for early retirement. In the bivariate regressions, none of our three measures of cognitive ability appear to influence likelihood of having retired early. In the multivariate analyses, the number series test, reflecting fluid cognitive abilities, and the verbal analogies test, reflecting both fluid and crystallized cognitive abilities, have conflicting influences. Those performing better on the number series test were slightly less likely to retire early, consistent with our hypotheses, but those with better verbal analogies scores were slightly more likely to retire early, contradicting our hypotheses.

Picture vocabulary scores, reflecting crystallized intelligence, had virtually no effect on early retirement. Those performing better on such scores, however, were slightly less likely to have a late retirement, contradicting our hypotheses. 
Table 3.7. Bivariate and multivariate regression analyses of reported early and late retirement.

\begin{tabular}{cllll}
\hline & \multicolumn{2}{c}{ Retired Before Age 62 } & \multicolumn{2}{c}{ Retired After FRA } \\
\cline { 2 - 5 } \multicolumn{1}{c}{ Predictor } & $\begin{array}{c}\text { Bivariate } \\
\text { Regressions }\end{array}$ & $\begin{array}{l}\text { Multivariate } \\
\text { Regression }\end{array}$ & $\begin{array}{c}\text { Bivariate } \\
\text { Regressions }\end{array}$ & $\begin{array}{l}\text { Multivariate } \\
\text { Regression }\end{array}$ \\
\hline Number series & -0.001 & -0.002 & -0.000 & 0.001 \\
Picture vocabulary & $(0.001)$ & $(0.001)^{\star \star}$ & $(0.001)$ & $(0.001)$ \\
Verbal analogies & 0.001 & 0.001 & -0.002 & -0.002 \\
Future time perspective & $(0.001)$ & $(0.001)$ & $(0.001)^{\star \star}$ & $(0.001)^{\star}$ \\
Focus on opportunities & 0.001 & 0.002 & -0.001 & -0.001 \\
& $(0.001)$ & $(0.001)^{\star}$ & $(0.001)$ & $(0.001)$ \\
Focus on limitations & 0.045 & 0.043 & -0.043 & -0.035 \\
& $(0.016)^{\star \star \star}$ & $(0.017)^{\star \star}$ & $(0.019)^{\star \star}$ & $(0.020)^{\star}$ \\
Expectations & 0.011 & 0.005 & -0.016 & -0.013 \\
Social security & $(0.017)$ & $(0.018)$ & $(0.020)$ & $(0.020)$ \\
& & & & -0.001 \\
& -0.000 & -0.000 & -0.001 & $(0.001)$ \\
\hline
\end{tabular}

* Two-sided $p$-value $<.10 ;{ }^{* \star} p<.05 ;{ }^{* \star \star} p<.01$

NOTE: Numbers reported are regression coefficients, with standard errors in parentheses. Within bivariate regressions, each predictor was entered as a single variable, coupled with the missingness indicator (not shown). Note that both future time perspective variables were entered together. Other control variables in the multivariate regressions include gender, marital status, education, wealth, health status, and age. Full regression results are presented in Appendix B. Results are qualitatively similar either excluding or imputing missing values.

Regarding future time perspective, those who focus on future opportunities were more likely to have an early retirement and less likely to have a late retirement. This is an interesting result and contrary to our hypothesis (H5). This may be the result of reverse causality: earlier retirement may promote a sense of opportunity or, alternately, be reserved disproportionately for those with greater opportunities. 
We found virtually no relationship between expectations of Social Security reform (and possible diminution of benefits) and early or late retirement. This contradicts our hypothesis that expectation of reform would lead to early retirement $(\mathrm{H} 4) .{ }^{12}$

\section{Recent retirees: earlier or later than expected}

To address whether recent retirees retired earlier or later than expected, RAND developed and fielded ALP questions for those respondents who reported having retired within the five years prior to the fielding of the survey. The ALP asked these individuals, "Was this about when you planned or expected to retire or was it earlier or later?" Response options included "I retired earlier than I had expected," "I retired about when I had expected," and "I retired later than I had expected." Of the 303 respondents who reported being currently partially or completely retired, 169 reported retiring earlier than expected, 117 reported retiring when they expected, and 17 reported retiring later than expected. Table 3.8 presents regression analyses using indicators of each of these responses as dependent variables

\footnotetext{
${ }^{12}$ We found no effect of our missingness indicators in these analyses. Financial literacy and maximizing tendencies were largely unrelated to these two dependent variables.
} 
Table 3.8. Bivariate and multivariate regression analyses of whether recent retirement was earlier than expected, as expected, or later than expected.

\begin{tabular}{|c|c|c|c|c|c|c|}
\hline \multirow[b]{2}{*}{ Predictor } & \multicolumn{2}{|c|}{ Earlier Than Expected } & \multicolumn{2}{|c|}{ As Expected } & \multicolumn{2}{|c|}{ Later Than Expected } \\
\hline & $\begin{array}{c}\text { Bivariate } \\
\text { Regressions }\end{array}$ & $\begin{array}{l}\text { Multivariate } \\
\text { Regression }\end{array}$ & $\begin{array}{c}\text { Bivariate } \\
\text { Regressions }\end{array}$ & $\begin{array}{l}\text { Multivariate } \\
\text { Regression }\end{array}$ & $\begin{array}{c}\text { Bivariate } \\
\text { Regressions }\end{array}$ & $\begin{array}{l}\text { Multivariate } \\
\text { Regression }\end{array}$ \\
\hline \multicolumn{7}{|l|}{ Cognitive ability } \\
\hline \multirow[t]{2}{*}{ Number series } & 0.000392 & 0.002197 & -0.000885 & -0.002550 & 0.000493 & 0.000353 \\
\hline & $(0.001)$ & $(0.002)$ & $(0.001)$ & $(0.002)$ & $(0.001)$ & $(0.001)$ \\
\hline \multirow[t]{2}{*}{ Picture vocabulary } & -0.001381 & -0.000087 & 0.000099 & -0.000837 & 0.001281 & 0.000924 \\
\hline & $(0.001)$ & $(0.001)$ & $(0.001)$ & $(0.001)$ & $(0.001)^{\star \star}$ & $(0.001)$ \\
\hline \multirow[t]{2}{*}{ Verbal analogies } & 0.001539 & 0.001961 & -0.001377 & -0.001503 & -0.000162 & -0.000458 \\
\hline & $(0.001)$ & $(0.001)$ & $(0.001)$ & $(0.001)$ & $(0.001)$ & $(0.001)$ \\
\hline \multicolumn{7}{|l|}{ Future time perspective } \\
\hline \multirow[t]{2}{*}{ Focus on opportunities } & 0.057016 & 0.033227 & -0.034800 & -0.023957 & -0.022216 & -0.009269 \\
\hline & $(0.023)^{\star \star}$ & $(0.024)$ & $(0.023)$ & $(0.025)$ & $(0.011)^{\star \star}$ & $(0.011)$ \\
\hline \multirow[t]{2}{*}{ Focus on limitations } & 0.037173 & 0.042791 & -0.027757 & -0.028640 & -0.009416 & -0.014151 \\
\hline & $(0.026)$ & $(0.026)$ & $(0.025)$ & $(0.027)$ & $(0.011)$ & $(0.010)$ \\
\hline \multicolumn{7}{|l|}{ Expectations } \\
\hline \multirow[t]{2}{*}{ Social security } & 0.000967 & 0.000916 & -0.000497 & -0.000812 & -0.000470 & -0.000104 \\
\hline & $(0.001)$ & $(0.001)$ & $(0.001)$ & $(0.001)$ & $(0.000)$ & $(0.000)$ \\
\hline
\end{tabular}

* Two-sided p-value $<.10 ;{ }^{* *} \mathrm{p}<.05 ;{ }^{* *} \mathrm{p}<.01$

NOTE: Numbers reported are regression coefficients, with standard errors in parentheses. Within bivariate regressions, each predictor was entered as a single variable, coupled with the missingness indicator (not shown). Note that both future time perspective variables were entered together. Other control variables in the multivariate regressions include gender, marital status, education, wealth, health status, and age. Full regression results are presented in Appendix B.

Results are qualitatively similar either excluding or imputing missing values. 
Those with higher Picture Vocabulary (crystallized intelligence) scores are more likely to say that they retired later than they expected. This effect was, however, reduced and nonsignificant once the analyses controlled for age. In bivariate regressions, those who focus on opportunities were more likely to report retiring earlier than they expected and less likely to say they retired later than they expected, but this effect diminishes when controlling for covariates, especially age. Those with higher financial literacy were less likely to report retiring earlier than expected $(\mathrm{b}=-.04, \mathrm{p}<.05)$ and more likely to report retiring as expected $(\mathrm{b}=.04, \mathrm{p}<.05)$. However, these effects are also reduced and nonsignificant once the analyses controlled for demographic characteristics. Those reporting having high standards (one aspect of maximizing tendencies) were moderately less likely to report retiring later than expected, an effect that held up even when controlling for age and other demographics $(b=-.03, p<.10) .{ }^{13}$

We also analyzed the three responses as a single ordinal variable, using an ordered-probit regression. This analysis provides additional power for detecting patterns across the three responses but presumes equivalent slopes across the three levels of the dependent variable. The ordered-probit results largely agree with the results of the binary probits in Table 3.9, but the results for future time perspective are stronger. In bivariate regressions, those with greater focus on opportunities were more likely to feel that their retirement was earlier rather than later than expected $(\mathrm{b}=-.16, \mathrm{p}<.01)$. After controlling for age and other demographics, this effect remained marginally significant $(b=-.12, p<.10)$. Those with a greater focus on limitations were, intriguingly, also more likely to report that retirement was earlier rather than later than expected $(b=-.15, p<.05)$, after controlling for age and other demographics.

\footnotetext{
${ }^{13}$ Future time perspective was not missing at random for these analyses, with the strongest effect for retiring earlier than expected. Generally speaking, those missing future time perspective data had a greater likelihood of reporting that they retired earlier than expected, when compared to those with future time perspective data. The mean expected likelihood of retiring earlier than expected (as opposed to as expected or later than expected) was $47.7 \%$ for those with future time perspective data and $68.9 \%$ for those missing future time perspective. The mean expected likelihood of retiring as expected (as opposed to earlier or later) was $44.4 \%$ for non-missing and $26.7 \%$ for missing. The mean expected likelihood of retiring later than expected (as opposed to earlier or as expected) was $7.9 \%$ for non-missing and $4.4 \%$ for missing. That said, parallel analyses dropping all observations with missing data gave qualitatively similar results to those in Table 3.8.
} 


\section{Conclusions}

\section{Summary}

In this work, we examined American Life Panel survey data to analyze six hypotheses regarding retirement behavior. We focused on three populations: persons who are not yet retired and for whom we have expectations about working later in life; persons who are already retired, and for whom we consider retirement age; and an additional sample of persons who have reported retiring in the past five years, whom we asked whether their retirement was earlier or later than expected. Each offered unique insights on our hypotheses regarding the effects of cognitive abilities, beliefs about the future, and maximizing behavior on retirement decision making.

Our first hypothesis was that those with greater cognitive abilities, including financial literacy, would be more likely to retire late. For those not yet retired, we found persons with higher cognitive ability, and in particular those with higher picture vocabulary test scores had a greater expectation of working full-time later in life. This was quite evident in those with a high (i.e., $\geq 80 \%$ ) expectation of working full-time after age 65 . Results for financial literacy were not quite as strong, but higher levels also indicated later expected retirement. Such results are entirely consistent with our first hypothesis.

For those already retired, we did not find cognitive ability to be associated with age of retirement, but we did see some relationships between cognitive ability and specific ranges of retirement age. Specifically, we found higher number series test scores, indicating higher levels of fluid intelligence, was associated with retiring after age 62, consistent with our hypothesis, but that higher picture vocabulary test scores, indicating higher levels of crystallized intelligence, was not, contrary to our hypothesis.

Our second hypothesis was that greater cognitive ability would lead to more coherent retirement expectations. We found strong evidence for this hypothesis. This suggests that those with lower cognitive ability think less coherently about retirement and may therefore benefit the most from assistance in retirement planning.

Our third and fourth hypotheses related to longevity and Social Security expectations. Specifically, our third hypothesis was that greater longevity expectations would lead to later retirement, while our fourth hypothesis was that greater expectation of future Social Security reform reducing personal benefits would lead to earlier retirement. We found greater longevity expectations (after controlling for life tables) were strongly and positively associated with greater 
expectation of working full-time after age 62 or age 65 . We also found such expectations were associated with a low perceived likelihood of stopping work before age $62 .^{14}$

We did not find evidence for our fourth hypothesis. Expectation of Social Security changes were positively associated with expectations of working full-time later in life, particularly after age 65 , contrary to our hypothesis. This may reflect our proposed alternative hypothesis - that a belief that changes in Social Security will require a longer working career for financial soundness in retirement. In contrast, we did not find much effect of Social Security expectations on retirement age or specifically early or late retirement. We also did not see much of an effect of Social Security expectations on whether retirement was earlier than expected, later than expected, or as expected. In sum, it appears as if expectations about Social Security changes are mostly related to expectations of retirement, rather than actual retirement or calibration of expectations.

Our fifth hypothesis was that focusing on opportunities (i.e., seeing a more expansive future) would lead individuals to choose later retirement, while focusing on limitations would lead to earlier retirement. We found mixed evidence on this. Among those not yet retired, we found perceptions of future opportunities were associated with greater expectation for working fulltime later in life, supporting our hypothesis, but controlling for age and other demographics largely accounted for this. Conversely, we found a focus on limitations was also positively associated with expectations of working full-time after age 65, contrary to our hypothesis. Among those already retired, we found focus of opportunities was associated with a lower retirement age, contrary to our hypothesis. Controlling for opportunities, we found no relationship between perception of limitations and retirement age.

Among recent retirees, we found that those focused on opportunities were more likely to retire earlier than expected and less likely to retire later than expected, contrary to our hypothesis. Intriguingly (since focus on opportunities is negatively correlated with focus on limitations), a greater focus on limitations was also associated with a lower chance of retiring later than expected, consistent with our hypothesis, and both had effects that were significant after controlling for age and other covariates.

It is possible that many of these mixed results stem, as earlier noted, from reverse causality, if early retirement in fact creates a feeling of great opportunity. This might explain why, for those who are retired, there is an association between early retirement and perception of opportunities, while those who are still working behave as we hypothesized, expecting to postpone retirement if focusing on future opportunities.

Finally, we hypothesized that maximizing behavior, particularly a tendency to continually search, will lead to later retirement. Within the pre-retirement subsample, continual search was associated with a planned later retirement—consistent with our hypothesis, but largely accounted

\footnotetext{
${ }^{14}$ Recall that, due to age restrictions, longevity expectations were not available for analyses regarding retirement age.
} 
by demographic characteristics. We also found that lower decision difficulty was associated with later retirement. By contrast, we found having high standards was associated with early retirement, contrary to our hypothesis, but only after controlling for other variables. Among those who are retired, we found that older retirement ages are associated with lower levels of continual searching - an effect contrary to our hypothesis, but also one that diminishes after controlling for age. We also found that having high standards was associated with a lower retirement age, also contrary to our hypotheses, but an effect evident only when controlling for other variables. These results suggest that the three different aspects of maximizing have differing effects on retirement behavior. Having high standards may lead persons to retire earlier, but continual searching and decision difficulty may reflects other aspects of respondent lives, especially given that other variables appear to account for their significance.

\section{Limitations}

Our analyses are subject to several limitations. First and foremost, our data are secondary, and as such have all the challenges associated with such data. In particular, many of the variables used here were created and fielded by other researchers and/or for other scientific purposes. Hence, the completeness and fit of the data to our hypotheses is not always perfect. The timing of the measurements was also dictated by prior research and not always a good fit for our purposes. That said, much of these data come from questions that have been well vetted and created by individuals with deep substantive expertise. The richness of the data also offer unique insights not available in most other data sets, and which would be very difficult to collect in an independent effort.

Second, one would ideally use longitudinal analyses rather than cross-sectional. Because our analyses are cross-sectional, different analyses involve different but somewhat overlapping subsamples, and hence are less comparable than they might be on a complete, longitudinal data set. That said, these psychological and economic variables are not available on most longitudinal datasets, and these results can provide a first glimpse at the issues we discuss.

Finally, some of our analyses are of somewhat small samples, and hence may lack statistical power. Hence, our results should be taken as suggestive and supportive of future research.

\section{Policy Implications}

Our results suggest that cognitive ability, and especially the crystallized cognitive ability captured by the picture vocabulary test, shapes how retirement is anticipated and experienced. Those with higher cognitive ability expect to retire later (even if they may not do so) and feel their actual retirement age was unexpectedly early - because it was contrary to their previous expectations. It is also worth noting that cognitive ability was not a major predictor of actual (self-reported) retirement age. This may suggest that a psychological expectation (or indeed, desire) to retire later may not be able to counter the influence of other health, wealth, and other 
characteristics influencing to retirement age. It also highlights the possibility that factors that influence pre-retirement decision making may not be the same factors that influence final decisions regarding the timing of actual retirement. If the case, this does not, however, diminish the importance of the pre-retirement relationships, as retirement expectations will shape decisions regarding retirement planning, and other career or non-career decisions that depend on these expectations.

Those with greater longevity expectations expected to retire later as well. Coupled with our findings on cognitive ability and retirement, this suggests a degree of rationality (or more weakly, good decision making) in decisions to retire later.

Expectation of Social Security changes that would reduce benefits appears to predict expectations of working later in life among ALP respondents. This contradicts our primary hypothesis, but supports a suggested counter-hypothesis. That is, this result may reflect a belief that changes in Social Security, and a resulting reduction in benefits, may require a longer working career for financial soundness in retirement. If these expectations affect pre-retirement behaviors, such as financial planning, then they may have unintended consequences. For example, if a worker expects a longer work life, there may be less incentive to invest in resources designed to benefit that worker in retirement (e.g., a vacation home).

Our finding that those with greater cognitive abilities have more coherent retirement expectations has important and immediate implications. Assuming that these findings do not stem from problems in response scale or difficulty with the underlying concepts, the results suggest that there may be segments of U.S. society that are systematically disadvantaged in retirement planning. A recent study on decision-making competence with adolescents (Jacobson et al., 2012) demonstrates that decision-making competence, which includes coherence in expectations, is a skill that can be improved with training. To the extent that this trainability extends to older adults, decision skills may be a useful target for intervention.

Regarding maximizing tendencies, we found two negative aspects—continually searching for better options and having difficulty with decisions - are associated with later retirement. Conversely, we found having high standards—itself not a negative predisposition—is associated with retiring earlier. This may suggest, contrary to our hypothesis, that those simply focusing on doing well for themselves, rather than struggling to find "the best," are valuing the benefits of early retirement more than the additional income and wealth gained by later retirement (recall that our analyses controlled for reported wealth). Past research on maximizing and job search suggests that whereas satisficing is associated with lower earnings, it may also be associated with less regret (Iyengar et al., 2006). As such, interventions designed to capitalize on different aspects of maximizing tendencies should tread carefully, since they could have unintended consequences on non-monetary aspects of well-being. 


\section{Future Directions}

This study is an attempt to expand the scope of retirement predictors beyond well-known economic and health variables by incorporating one set of psychological variables. It relied on data available in the ALP, an unusually diverse data resource. That said, future work should further expand this data, and do so in a targeted fashion. For example, recent developments in behavior measures of decision-making competence (Bruine de Bruin et al., 2007), which includes a task specifically targeting the coherence of expectations, may provide a set of predictors more proximal to real-world behavior than are general cognitive abilities. A targeted assessment of expectation coherence would also facilitate examining its relationship to actual retirement age (in this study, expectations were only available on the pre-retirement subsample).

Similarly, some of the relationships examined here are suggestive and at times surprising. In particular, our results on future time perspectives may indicate more complex relationships than we hypothesized between such perspectives and retirement decision making. Future research should consider whether a focus on opportunities or limitations may be an outcome of major life events such as retirement as much as a cause.

Another logical extension of our research would be assessing these predictors within a longitudinal design (perhaps within an existing panel study). This would provide for stronger temporal ordering, and hence help identify potential causal relationships, as well as allow for examination of change. Of particular importance is addressing potential endogeneities between retirement itself and several of the predictors discussed here, such as the relationship between future time perspective and retirement. A longitudinal design would also allow for a direct comparison between retirement expectation coherence and retirement age.

Ultimately, these results suggest that efforts to improve decision making should account for psychological considerations. With more targeted measurement and larger samples, the psychological influence on retirement behavior may be important additions to traditional economic and health variables that researchers have analyzed. 


\section{Appendix A. Age to receive full Social Security benefits}

SSA defines this age (called "full retirement age" or "normal retirement age") by year of birth, as mapped out in Table A.1.

Table A.1. Age to Receive Full Social Security Benefits

\begin{tabular}{cc}
\hline Year of Birth & Full Retirement Age \\
\hline 1937 or earlier & 65 \\
1938 & 65 and 2 months \\
1939 & 65 and 4 months \\
1940 & 65 and 6 months \\
1941 & 65 and 8 months \\
1942 & 65 and 10 months \\
$1943-1954$ & 66 \\
1955 & 66 and 2 months \\
1956 & 66 and 4 months \\
1957 & 66 and 6 months \\
1958 & 66 and 8 months \\
1959 & 66 and 10 months \\
1960 and later & 67 \\
\hline
\end{tabular}

Note: If an individual was born on January 1st of any year, that person should refer to the previous year. (If that person was born on the 1st of the month, SSA figures his or her benefit (and full retirement age) as if the birthday was in the previous month.

Source: http://www.ssa.gov/retire2/retirechart.htm.

Individuals may choose to start receiving SS benefits as early as age 62 (earlier in some cases) and as late as age 70. Choosing to take SS benefits before the full retirement age results in a penalty (equal to 5/9\% for each month, up to 36 months, and 5/12\% for each month beyond that). So, for example, someone born in 1960 who chooses to retire at age 62 would receive $70 \%$ (100 minus 5/9*36 plus 5/12*24) of the monthly benefit that they would have received if they had retired at age 67 (their full retirement age). Conversely, those who retire late get a credit (which also depends on year of birth). For example, that same person choosing to claim SS benefits at age 70 would get $124 \%$ of the monthly benefit that they would have received if they 
had retired at age $67 .{ }^{15}$ Choices to retire earlier or later than the SS full retirement age may reflect economic, family/social, or psychological characteristics of the individual.

${ }^{15}$ http://www.ssa.gov/OACT/ProgData/ar_drc.html. 


\section{Appendix B. Full regression results}

This appendix provides detailed results for each of the regression analyses presented in the main report. For each dependent variable, three tables are provided: (a) bivariate probit regressions, (b) multivariate probit regressions, and (c) bivariate and multivariate probit regressions specifically for financial literacy and maximizing tendencies.

Each table contains multiple regressions, presented as separate columns. Generally, the columns to the right contain more predictors, with the final column being the complete specification.

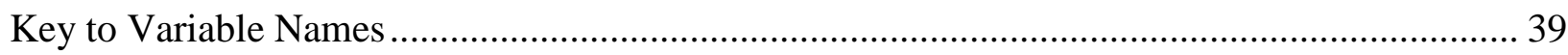

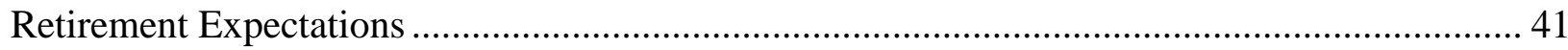

Table B1a. Expectation of Working Full-time After Age 62 (P62) ....................................................... 41

Table B1b. Expectation of Working Full-time After Age 62 (P62) ....................................................... 42

Table B1c. Expectation of Working Full-time After Age 62 (P62) ....................................................... 44

Table B2a. Expectation of Working Full-time After Age 65 (P65) ...........................................................4 46

Table B2b. Expectation of Working Full-time After Age 65 (P65) ……………………………......... 47

Table B2c. Expectation of Working Full-time After Age 65 (P65) ......................................................50

Table B3a. Planning to Retire Late $(\mathrm{P} 65>80 \%)$............................................................................. 52

Table B3b. Planning to Retire Late $(\mathrm{P} 65>80 \%)$.............................................................................. 53

Table B3c. Planning to Retire Late $(\mathrm{P} 65>80 \%)$.............................................................................. 55

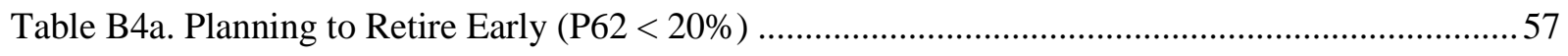

Table B4b. Planning to Retire Early (P62 < 20\%) ………….......................................................... 58

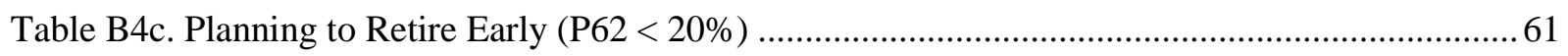

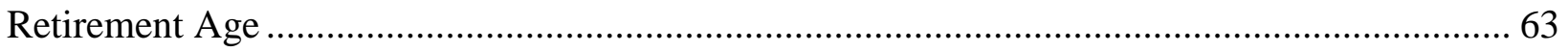

Table B5a. Retirement Age ......................................................................................................... 63

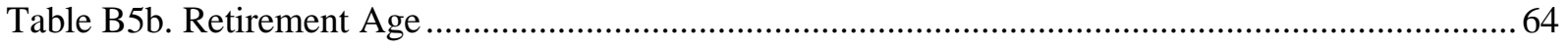

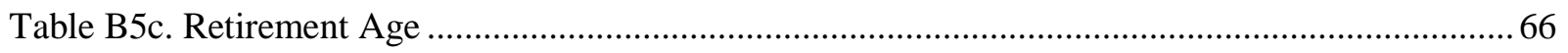

Table B6a. Retired Before Age 62 .............................................................................................. 68

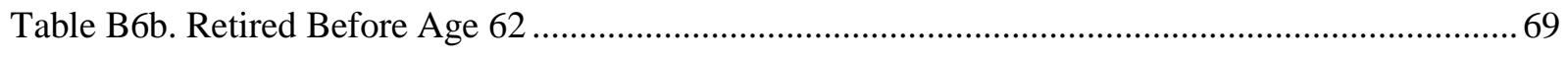

Table B6c. Retired Before Age 62 ................................................................................................ 71

Table B7a. Retired After the Full Retirement Age........................................................................... 72

Table B7b. Retired After the Full Retirement Age.......................................................................... 73

Table B7c. Retired After the Full Retirement Age....................................................................... 75

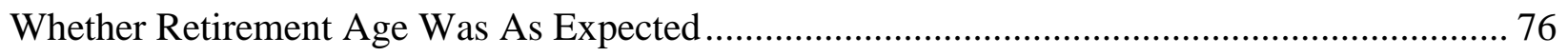

Table B8a. Retired Earlier Than Expected.................................................................................... 76

Table B8b. Retired Earlier Than Expected............................................................................................. 77

Table B8c. Retired Earlier Than Expected .................................................................................... 79

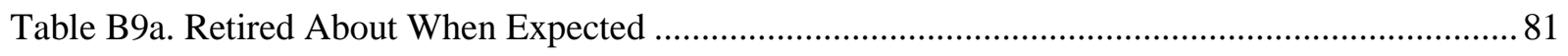




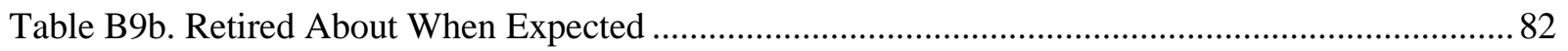

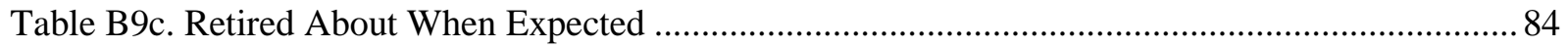

Table B10a. Retired Later Than Expected ....................................................................................... 86

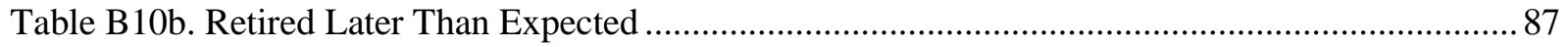

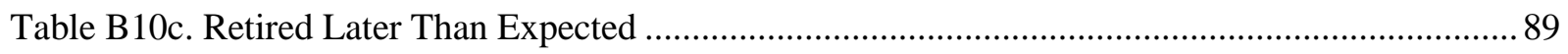




\begin{tabular}{|c|c|}
\hline Code Variable & Description \\
\hline ms286_W_NSA & Cognitive ability: Number series \\
\hline ms286_W_PVA & Cognitive ability: Picture vocabulary \\
\hline ms286_W_VAA & Cognitive ability: Verbal analogies \\
\hline focus_opport & Focus on opportunities \\
\hline focus_limit & Focus on limitations \\
\hline SS_expectations & Social Security expectations \\
\hline longevity_ratio & Longevity ratio \\
\hline financial_lit_index & Financial literacy index \\
\hline high_standards & Maximizing: having high standards \\
\hline continual_search & Maximizing: continual search \\
\hline decision_difficulty & Maximizing: decision difficulty \\
\hline age_45_49 & Age 45 to 49 \\
\hline age_50_54 & Age 50 to 54 \\
\hline age_55_59 & Age 55 to 59 \\
\hline age_60_64 & Age 60 to 64 \\
\hline age_65_69 & Age 65 to 69 \\
\hline male & Male \\
\hline married & Married \\
\hline divorced & Divorced \\
\hline high_school & High school graduate \\
\hline some_college & At least some college \\
\hline college_graduate & College graduate \\
\hline middle_wealth & Middle wealth \\
\hline high_wealth & High wealth \\
\hline better_health & Excellent or very good health \\
\hline
\end{tabular}


Code Variable

poor_health

missing_cog_abilities

missing_fut_time_pers

missing_SS_expectations

missing_wealth_2

\section{Description}

Fair or poor health

Missing indicator: Cognitive abilities

Missing indicator: Future time perspective

Missing indicator: Social Security expectations

Missing indicator: Wealth 


\section{Retirement Expectations}

Table B1a. Expectation of Working Full-time After Age 62 (P62)

\begin{tabular}{|c|c|c|c|c|c|c|c|c|}
\hline \multirow[b]{2}{*}{ VARIABLES } & (1) & (2) & (3) & (4) & (5) & (6) & (7) & (8) \\
\hline & \multicolumn{8}{|c|}{ Probability Working Full-Time After 62} \\
\hline \multirow[t]{2}{*}{ Cognitive ability: Number series } & 0.089 & & & 0.046 & & & & 0.017 \\
\hline & $(0.038)^{\star \star}$ & & & $(0.046)$ & & & & $(0.045)$ \\
\hline \multirow[t]{2}{*}{ Cognitive ability: Picture vocabulary } & & 0.127 & & 0.107 & & & & 0.090 \\
\hline & & $(0.038)^{\star \star \star}$ & & $(0.043)^{\star \star}$ & & & & $(0.042)^{\star \star}$ \\
\hline \multirow[t]{2}{*}{ Cognitive ability: Verbal analogies } & & & 0.080 & 0.011 & & & & -0.004 \\
\hline & & & $(0.039)^{\star \star}$ & $(0.049)$ & & & & $(0.048)$ \\
\hline \multirow[t]{2}{*}{ Focus on opportunities } & & & & & 1.704 & & & 1.097 \\
\hline & & & & & $(0.776)^{\star \star}$ & & & $(0.759)$ \\
\hline \multirow[t]{2}{*}{ Focus on limitations } & & & & & 0.467 & & & 0.719 \\
\hline & & & & & $(0.840)$ & & & $(0.825)$ \\
\hline \multirow[t]{2}{*}{ Longevity ratio } & & & & & & 20.066 & & 19.554 \\
\hline & & & & & & $(2.317)^{\star \star \star}$ & & $(2.345)^{\star * *}$ \\
\hline \multirow[t]{2}{*}{ Social Security expectations } & & & & & & & 0.111 & 0.099 \\
\hline & & & & & & & $(0.032)^{\star \star \star}$ & $(0.032)^{\star \star *}$ \\
\hline \multirow[t]{2}{*}{ Missing indicator: Cognitive abilities } & 49.462 & 73.352 & 44.069 & 92.393 & & & & 61.403 \\
\hline & $(20.552)^{\star \star}$ & $(21.285)^{\star \star \star}$ & $(20.800)^{\star \star}$ & $(26.358)^{\star \star \star}$ & & & & $(26.537)^{\star \star}$ \\
\hline \multirow[t]{2}{*}{ Missing indicator: Future time perspective } & & & & & & & & 4.179 \\
\hline & & & & & & & & $(5.957)$ \\
\hline \multirow[t]{2}{*}{ Missing indicator: Social Security expectations } & & & & & & & -1.690 & 6.780 \\
\hline & & & & & & & $(19.635)$ & $(19.945)$ \\
\hline \multirow[t]{2}{*}{ Constant } & 12.491 & -11.399 & 17.884 & -30.440 & 51.352 & 43.256 & 53.024 & -27.753 \\
\hline & $(20.457)$ & $(21.193)$ & $(20.706)$ & $(26.283)$ & $(5.723)^{\star \star \star}$ & $(2.115)^{\star \star \star}$ & $(2.198)^{\star \star \star}$ & $(26.710)$ \\
\hline Observations & 1,864 & 1,864 & 1,864 & 1,864 & 1,864 & 1,864 & 1,864 & 1,864 \\
\hline
\end{tabular}

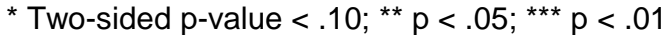

NOTE: Numbers reported are regression coefficients, with standard errors in parentheses. 
Table B1b. Expectation of Working Full-time After Age 62 (P62)

\begin{tabular}{|c|c|c|c|c|c|c|c|c|c|c|}
\hline \multirow[b]{2}{*}{ VARIABLES } & (1) & (2) & (3) & (4) & (5) & (6) & (7) & (8) & (9) & (10) \\
\hline & \multicolumn{10}{|c|}{ Probability Working Full-Time After 62} \\
\hline \multirow[t]{2}{*}{$\begin{array}{l}\text { Cognitive ability: Number } \\
\text { series }\end{array}$} & & 0.044 & & & 0.004 & & & & -0.001 & -0.005 \\
\hline & & $(0.040)$ & & & $(0.046)$ & & & & $(0.046)$ & $(0.046)$ \\
\hline \multirow[t]{2}{*}{$\begin{array}{l}\text { Cognitive ability: Picture } \\
\text { vocabulary }\end{array}$} & & & 0.117 & & 0.111 & & & & 0.101 & 0.106 \\
\hline & & & $(0.038)^{\star \star \star}$ & & $(0.043)^{\star \star}$ & & & & $(0.042)^{\star \star}$ & $(0.042)^{\star \star}$ \\
\hline \multirow[t]{2}{*}{$\begin{array}{l}\text { Cognitive ability: Verbal } \\
\text { analogies }\end{array}$} & & & & 0.058 & 0.014 & & & & 0.007 & 0.009 \\
\hline & & & & $(0.039)$ & $(0.048)$ & & & & $(0.047)$ & $(0.047)$ \\
\hline \multirow[t]{2}{*}{ Focus on opportunities } & & & & & & 1.129 & & & 0.778 & 0.634 \\
\hline & & & & & & $(0.760)$ & & & $(0.747)$ & $(0.756)$ \\
\hline \multirow[t]{2}{*}{ Focus on limitations } & & & & & & 0.422 & & & 0.653 & 0.702 \\
\hline & & & & & & $(0.825)$ & & & $(0.814)$ & $(0.821)$ \\
\hline \multirow[t]{2}{*}{ Longevity ratio } & & & & & & & 16.808 & & 16.979 & 17.044 \\
\hline & & & & & & & $(2.408)^{\star \star \star}$ & & $(2.414)^{\star \star \star}$ & $(2.416)^{\star \star \star}$ \\
\hline \multirow[t]{2}{*}{ Social Security expectations } & & & & & & & & 0.115 & 0.110 & 0.107 \\
\hline & & & & & & & & $(0.031)^{\star \star \star}$ & $(0.031)^{\star \star \star}$ & $(0.032)^{\star \star \star}$ \\
\hline \multirow[t]{2}{*}{ Age 45 to 49} & & & & & & & & & & -32.681 \\
\hline & & & & & & & & & & $(4.252)^{\star \star \star}$ \\
\hline \multirow[t]{2}{*}{ Age 50 to 54} & & & & & & & & & & -30.885 \\
\hline & & & & & & & & & & $(4.335)^{\star \star \star}$ \\
\hline \multirow[t]{2}{*}{ Age 55 to 59} & & & & & & & & & & -33.457 \\
\hline & & & & & & & & & & $(4.508)^{\star \star \star}$ \\
\hline \multirow[t]{2}{*}{ Age 60 to 64} & & & & & & & & & & -35.383 \\
\hline & & & & & & & & & & $(5.104)^{\star \star \star}$ \\
\hline \multirow[t]{2}{*}{ Male } & 7.312 & 7.083 & 7.145 & 7.337 & 7.155 & 7.462 & 6.754 & 7.099 & 6.516 & 6.590 \\
\hline & $(1.662)^{\star \star \star}$ & $(1.668)^{\star \star \star}$ & $(1.660)^{\star \star \star}$ & $(1.663)^{\star \star \star}$ & $(1.672)^{\star \star \star}$ & $(1.667)^{\star \star \star}$ & $(1.646)^{\star \star \star}$ & $(1.659)^{\star \star \star}$ & $(1.659)^{\star \star \star}$ & $(1.663)^{\star \star \star}$ \\
\hline \multirow[t]{2}{*}{ Married } & -7.068 & -7.235 & -7.579 & -7.301 & -7.635 & -7.035 & -7.380 & -7.768 & -8.572 & -8.468 \\
\hline & $(2.134)^{\star \star \star}$ & $(2.139)^{\star \star \star}$ & $(2.127)^{\star \star \star}$ & $(2.140)^{\star \star \star}$ & $(2.132)^{\star \star \star}$ & $(2.136)^{\star \star \star}$ & $(2.090)^{\star \star \star}$ & $(2.118)^{\star \star \star}$ & $(2.072)^{\star \star \star}$ & $(2.071)^{\star \star \star}$ \\
\hline
\end{tabular}




\begin{tabular}{|c|c|c|c|c|c|c|c|c|c|c|}
\hline \multirow[b]{2}{*}{ VARIABLES } & (1) & (2) & (3) & (4) & (5) & (6) & (7) & (8) & (9) & (10) \\
\hline & \multicolumn{10}{|c|}{ Probability Working Full-Time After 62} \\
\hline \multirow[t]{2}{*}{ Divorced } & 3.797 & 3.803 & 3.852 & 3.722 & 3.840 & 3.914 & 3.794 & 3.400 & 3.462 & 3.651 \\
\hline & (2.649) & $(2.648)$ & (2.638) & (2.647) & (2.638) & (2.658) & (2.599) & (2.635) & (2.589) & (2.599) \\
\hline \multirow[t]{2}{*}{ High school graduate } & 11.045 & 10.668 & 10.341 & 10.666 & 10.262 & 11.034 & 9.976 & 11.188 & 9.279 & 9.478 \\
\hline & $(3.551)^{\star \star \star}$ & $(3.560)^{\star \star \star}$ & $(3.550)^{\star \star \star}$ & $(3.554)^{\star \star \star}$ & $(3.556)^{\star \star \star}$ & $(3.565)^{\star \star \star}$ & $(3.444)^{\star \star \star}$ & $(3.540)^{\star \star \star}$ & $(3.457)^{\star \star \star}$ & $(3.457)^{\star \star \star}$ \\
\hline \multirow[t]{2}{*}{ At least some college } & 11.948 & 11.626 & 11.190 & 11.502 & 11.065 & 11.688 & 10.469 & 11.683 & 9.184 & 9.414 \\
\hline & $(3.369)^{\star \star \star}$ & $(3.386)^{\star \star \star}$ & $(3.365)^{\star \star \star}$ & $(3.383)^{\star \star \star}$ & $(3.385)^{\star \star \star}$ & $(3.386)^{\star \star \star}$ & $(3.267)^{\star \star \star}$ & $(3.364)^{\star \star \star}$ & $(3.301)^{\star \star \star}$ & $(3.313)^{\star \star \star}$ \\
\hline \multirow[t]{2}{*}{ College_graduate } & 13.870 & 13.219 & 12.936 & 13.165 & 12.745 & 13.542 & 11.130 & 13.541 & 9.453 & 9.669 \\
\hline & $(3.431)^{\star \star \star}$ & $(3.488)^{\star \star \star}$ & $(3.438)^{\star \star \star}$ & $(3.466)^{\star \star \star}$ & $(3.491)^{\star \star \star}$ & $(3.451)^{\star \star \star}$ & $(3.342)^{\star \star \star}$ & $(3.421)^{\star \star \star}$ & $(3.414)^{\star \star \star}$ & $(3.428)^{\star \star \star}$ \\
\hline \multirow[t]{2}{*}{ Middle wealth } & 2.794 & 2.563 & 2.319 & 2.482 & 2.248 & 2.851 & 2.407 & 2.574 & 1.755 & 1.918 \\
\hline & $(1.982)$ & $(1.984)$ & $(1.982)$ & (1.983) & $(1.983)$ & $(1.984)$ & $(1.947)$ & $(1.973)$ & $(1.941)$ & $(1.941)$ \\
\hline \multirow[t]{2}{*}{ High wealth } & -3.190 & -3.482 & -4.108 & -3.585 & -4.190 & -3.090 & -3.874 & -3.692 & -5.204 & -4.878 \\
\hline & $(2.207)$ & $(2.218)$ & $(2.214)^{\star}$ & $(2.210)$ & $(2.216)^{\star}$ & $(2.206)$ & $(2.183)^{\star}$ & $(2.206)^{\star}$ & $(2.192)^{\star \star}$ & $(2.202)^{\star \star}$ \\
\hline \multirow[t]{2}{*}{ Excellent or very good health } & 3.773 & 3.863 & 3.906 & 3.801 & 3.890 & 3.539 & 1.747 & 3.811 & 1.884 & 2.000 \\
\hline & $(1.824)^{\star \star}$ & $(1.826)^{\star \star}$ & $(1.820)^{\star \star}$ & $(1.827)^{\star \star}$ & $(1.822)^{\star \star}$ & $(1.828)^{\star}$ & $(1.819)$ & $(1.822)^{\star \star}$ & $(1.818)$ & $(1.820)$ \\
\hline \multirow[t]{2}{*}{ Fair or poor health } & -14.291 & -14.285 & -14.206 & -14.418 & -14.221 & -13.966 & -12.417 & -14.611 & -12.374 & -12.313 \\
\hline & $(2.903)^{\star \star \star}$ & $(2.899)^{\star \star \star}$ & $(2.903)^{\star \star \star}$ & $(2.901)^{\star \star \star}$ & $(2.906)^{\star \star \star}$ & $(2.902)^{\star \star \star}$ & $(2.843)^{\star \star \star}$ & $(2.883)^{\star \star \star}$ & $(2.825)^{\star \star \star}$ & $(2.823)^{\star \star \star}$ \\
\hline \multirow[t]{2}{*}{$\begin{array}{l}\text { Missing indicator: Cognitive } \\
\text { abilities }\end{array}$} & & 26.057 & 67.776 & 33.178 & 73.673 & & & & 63.443 & 65.521 \\
\hline & & $(21.250)$ & $(21.350)^{\star \star \star}$ & $(20.799)$ & $(26.952)^{\star \star \star}$ & & & & $(27.354)^{\star \star}$ & $(27.458)^{\star \star}$ \\
\hline \multirow[t]{2}{*}{$\begin{array}{l}\text { Missing indicator: Future time } \\
\text { perspective }\end{array}$} & & & & & & 4.548 & & & 2.805 & 2.239 \\
\hline & & & & & & $(5.909)$ & & & $(5.849)$ & $(5.872)$ \\
\hline \multirow[t]{2}{*}{$\begin{array}{l}\text { Missing indicator: Social } \\
\text { Security expectations }\end{array}$} & & & & & & & & -1.306 & 6153 & 5110 \\
\hline & & & & & & & & $(19.357)$ & $\begin{array}{c}0.135 \\
(18.435)\end{array}$ & $(19.285)$ \\
\hline \multirow[t]{2}{*}{ Missing indicator: Wealth } & 7.836 & 7.902 & 7.562 & 7.716 & 7.492 & 7.303 & 5.906 & 7.168 & 4.619 & 4.777 \\
\hline & $(7.882)$ & $(7.905)$ & $(7.708)$ & $(7.896)$ & $(7.719)$ & $(7.921)$ & $(7.868)$ & $(8.071)$ & $(7.934)$ & $(7.806)$ \\
\hline \multirow[t]{2}{*}{ Constant } & 48.784 & 25.688 & -15.329 & 18.673 & -21.010 & 42.706 & 38.107 & 42.417 & -32.026 & -1.346 \\
\hline & $(3.502)^{\star \star \star}$ & $(20.721)$ & $(21.033)$ & $(20.410)$ & $(26.335)$ & $(6.539)^{\star \star \star}$ & $(3.701)^{\star \star \star}$ & $(3.893)^{\star \star \star}$ & $(27.252)$ & $(26.370)$ \\
\hline Observations & 1,864 & 1,864 & 1,864 & 1,864 & 1,864 & 1,864 & 1,864 & 1,864 & 1,864 & 1,864 \\
\hline
\end{tabular}

NOTE: Numbers reported are regression coefficients, with standard errors in parentheses. 
Table B1c. Expectation of Working Full-time After Age 62 (P62)

\begin{tabular}{|c|c|c|c|c|c|c|}
\hline \multirow[b]{2}{*}{ VARIABLES } & (1) & $(2)$ & (3) & (4) & (5) & (6) \\
\hline & \multicolumn{6}{|c|}{ Probability Working Full-Time After 62} \\
\hline \multirow[t]{2}{*}{ Financial literacy index } & 1.110 & 0.333 & 0.333 & & & \\
\hline & $(0.630)^{\star}$ & $(0.730)$ & $(0.734)$ & & & \\
\hline \multirow{3}{*}{$\begin{array}{l}\text { Maximizing: having high } \\
\text { standards }\end{array}$} & & & & & & \\
\hline & & & & -1.283 & -1.870 & -1.820 \\
\hline & & & & $(1.059)$ & $(1.046)^{\star}$ & $(1.047)^{\star}$ \\
\hline \multirow[t]{2}{*}{ Maximizing: continual search } & & & & 1.917 & 0.797 & 0.689 \\
\hline & & & & $(1.085)^{\star}$ & $(1.068)$ & $(1.076)$ \\
\hline \multirow[t]{2}{*}{ Maximizing: decision difficulty } & & & & -1.853 & -1.211 & -1.136 \\
\hline & & & & $(0.947)^{\star}$ & $(0.942)$ & $(0.944)$ \\
\hline \multirow[t]{2}{*}{ Age 45 to 49} & & & & & & 5.851 \\
\hline & & & & & & $(3.780)$ \\
\hline \multirow[t]{2}{*}{ Age 50 to 54} & & & 1.514 & & & 5.795 \\
\hline & & & (2.571) & & & $(3.802)$ \\
\hline \multirow[t]{2}{*}{ Age 55 to 59} & & & 0.235 & & & 2.522 \\
\hline & & & $(2.622)$ & & & $(3.806)$ \\
\hline \multirow[t]{2}{*}{ Age 60 to 64} & & & -4.691 & & & \\
\hline & & & (3.584) & & & \\
\hline \multirow[t]{2}{*}{ Male } & & 7.331 & 7.547 & & 8.331 & 8.345 \\
\hline & & $(2.155)^{\star \star \star}$ & $(2.159)^{\star \star \star}$ & & $(2.218)^{\star \star \star}$ & $(2.220)^{\star \star \star}$ \\
\hline \multirow[t]{2}{*}{ Married } & & -8.748 & -8.554 & & -8.943 & -8.614 \\
\hline & & $(2.831)^{\star \star \star}$ & $(2.831)^{\star \star \star}$ & & $(2.999)^{\star \star \star}$ & $(2.996)^{\star \star \star}$ \\
\hline \multirow[t]{2}{*}{ Divorced } & & 3.877 & 4.050 & & 5.918 & 6.370 \\
\hline & & (3.404) & (3.415) & & $(3.587)^{\star}$ & $(3.599)^{\star}$ \\
\hline \multirow[t]{2}{*}{ High school graduate } & & 17.122 & 17.429 & & 18.028 & 18.169 \\
\hline & & $(5.325)^{\star \star \star}$ & $(5.315)^{\star \star \star}$ & & $(5.493)^{\star \star \star}$ & $(5.514)^{\star \star \star}$ \\
\hline \multirow[t]{2}{*}{ At least some college } & & 18.241 & 18.559 & & 18.684 & 19.018 \\
\hline & & $(5.206)^{\star \star \star}$ & $(5.203)^{\star \star \star}$ & & $(5.285)^{\star \star \star}$ & $(5.326)^{\star \star \star}$ \\
\hline \multirow[t]{2}{*}{ College_graduate } & & 19.935 & 20.142 & & 21.267 & 21.539 \\
\hline & & $(5.348)^{\star \star \star}$ & $(5.346)^{\star \star \star}$ & & $(5.301)^{\star \star \star}$ & $(5.344)^{\star \star \star}$ \\
\hline \multirow[t]{2}{*}{ Middle wealth } & & 0.290 & 0.571 & & -0.042 & 0.241 \\
\hline & & $(2.540)$ & (2.534) & & $(2.710)$ & (2.705) \\
\hline \multirow[t]{2}{*}{ High wealth } & & -6.752 & -6.153 & & -6.524 & -5.744 \\
\hline & & $(2.803)^{\star \star}$ & $(2.799)^{\star *}$ & & $(2.826)^{\star \star}$ & $(2.820)^{\star \star}$ \\
\hline \multirow[t]{2}{*}{ Excellent or very good health } & & 2.590 & 2.486 & & 3.644 & 3.589 \\
\hline & & $(2.265)$ & $(2.262)$ & & (2.414) & $(2.405)$ \\
\hline \multirow[t]{2}{*}{ Fair or poor health } & & -18.762 & -18.688 & & -19.080 & -19.096 \\
\hline & & $(4.111)^{\star \star \star}$ & $(4.103)^{\star \star \star}$ & & $(4.411)^{\star \star \star}$ & $(4.396)^{\star \star \star}$ \\
\hline \multirow[t]{2}{*}{ Missing indicator: Wealth } & & -3.162 & -2.941 & & -4.490 & -4.174 \\
\hline & & $(10.217)$ & $(10.038)$ & & $(10.131)$ & $(9.964)$ \\
\hline \multirow[t]{2}{*}{ Constant } & 60.529 & 47.485 & 46.849 & 67.282 & 56.319 & 51.226 \\
\hline & $(1.061)^{\star \star \star}$ & $(5.619)^{\star \star \star}$ & $(5.763)^{\star \star \star}$ & $(6.113)^{\star \star \star}$ & $(7.759)^{\star \star \star}$ & $(8.488)^{\star \star \star}$ \\
\hline
\end{tabular}


(1)

VARIABLES

(2)

(3)

(4)

Probability Working Full-Time After 62

1,196

1,196

1,196

1,098

1,098

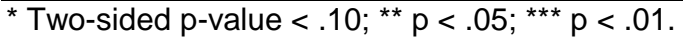

NOTE: Numbers reported are regression coefficients, with standard errors in parentheses.
(6)

1,098


Table B2a. Expectation of Working Full-time After Age 65 (P65)

\begin{tabular}{|c|c|c|c|c|c|c|c|c|}
\hline \multirow[b]{2}{*}{ VARIABLES } & (1) & (2) & (3) & (4) & (5) & (6) & (7) & (8) \\
\hline & \multicolumn{8}{|c|}{ Probability Working Full-Time After 65} \\
\hline \multirow[t]{2}{*}{ Cognitive ability: Number series } & 0.074 & & & 0.048 & & & & 0.012 \\
\hline & $(0.034)^{\star \star}$ & & & $(0.040)$ & & & & $(0.040)$ \\
\hline Cognitive ability: Picture vocabulary & & $(0.033)^{\star \star \star}$ & & $(0.038)^{\star}$ & & & & $(0.037)$ \\
\hline \multirow[t]{2}{*}{ Cognitive ability: Verbal analogies } & & & 0.057 & 0.003 & & & & -0.010 \\
\hline & & & $(0.035)$ & $(0.043)$ & & & & $(0.042)$ \\
\hline Focus on opportunities & & & & & $(0.688)^{\star \star \star}$ & & & $(0.669)^{\star}$ \\
\hline \multirow[t]{2}{*}{ Focus on limitations } & & & & & 1.312 & & & 1.542 \\
\hline & & & & & $(0.737)^{\star}$ & & & $(0.718)^{\star \star}$ \\
\hline \multirow[t]{2}{*}{ Longevity ratio } & & & & & & 19.554 & & 19.399 \\
\hline & & & & & & $(2.034)^{\star \star \star}$ & & $(2.068)^{\star \star \star}$ \\
\hline Social Security expectations & & & & & & & 0.116 & 0.107 \\
\hline $\begin{array}{l}\text { Missing indicator: Future time } \\
\text { perspective }\end{array}$ & & & & & & & & $(5.147)^{\star}$ \\
\hline \multirow{2}{*}{$\begin{array}{l}\text { Missing indicator: Social Security } \\
\text { expectations }\end{array}$} & & & & & & & 21315 & -13657 \\
\hline & & & & & & & $(4.080)^{\star \star \star}$ & $(4.616)^{\star \star \star}$ \\
\hline \multirow[t]{2}{*}{ Constant } & 2.256 & -8.581 & 11.795 & -26.408 & 29.097 & 25.584 & 34.648 & -24.673 \\
\hline & $(18.114)$ & $(18.637)$ & $(18.257)$ & $(23.226)$ & $(4.990)^{\star \star \star}$ & $(1.788)^{\star \star \star}$ & $(1.914)^{\star \star \star}$ & (23.747) \\
\hline Observations & 2,056 & 2,056 & 2,056 & 2,056 & 2,056 & 2,056 & 2,056 & 2,056 \\
\hline
\end{tabular}

* Two-sided $\mathrm{p}$-value $<.10 ;{ }^{* \star} \mathrm{p}<.05 ;{ }^{* \star \star} \mathrm{p}<.01$.

NOTE: Numbers reported are regression coefficients, with standard errors in parentheses. 
Table B2b. Expectation of Working Full-time After Age 65 (P65)

\begin{tabular}{|c|c|c|c|c|c|c|c|c|c|c|}
\hline & (1) & (2) & (3) & (4) & (5) & (6) & $(7)$ & (8) & (9) & (10) \\
\hline VARIABLES & \multicolumn{10}{|c|}{ Probability Working Full-Time After 65} \\
\hline \multirow[t]{2}{*}{$\begin{array}{l}\text { Cognitive ability: Number } \\
\text { series }\end{array}$} & & 0.059 & & & 0.026 & & & & 0.015 & 0.011 \\
\hline & & $(0.036)$ & & & $(0.041)$ & & & & $(0.041)$ & $(0.041)$ \\
\hline \multirow{3}{*}{$\begin{array}{l}\text { Cognitive ability: Picture } \\
\text { vocabulary }\end{array}$} & & & & & & & & & & \\
\hline & & & 0.100 & & 0.087 & & & & 0.076 & 0.087 \\
\hline & & & $(0.034)^{\star \star \star}$ & & $(0.037)^{\star \star}$ & & & & $(0.037)^{\star \star}$ & $(0.037)^{\star \star}$ \\
\hline \multirow[t]{2}{*}{$\begin{array}{l}\text { Cognitive ability: Verbal } \\
\text { analogies }\end{array}$} & & & & 0.060 & 0.016 & & & & 0.010 & 0.011 \\
\hline & & & & $(0.036)^{\star}$ & $(0.043)$ & & & & $(0.042)$ & $(0.042)$ \\
\hline \multirow[t]{2}{*}{ Focus on opportunities } & & & & & & 1.357 & & & 0.978 & 0.717 \\
\hline & & & & & & $(0.677)^{\star \star}$ & & & $(0.660)$ & $(0.668)$ \\
\hline \multirow[t]{2}{*}{ Focus on limitations } & & & & & & 1.200 & & & 1.425 & 1.578 \\
\hline & & & & & & $(0.720)^{\star}$ & & & $(0.704)^{\star \star}$ & $(0.708)^{\star \star}$ \\
\hline \multirow[t]{2}{*}{ Longevity ratio } & & & & & & & 17.993 & & 18.340 & 18.418 \\
\hline & & & & & & & $(2.141)^{\star \star \star}$ & & $(2.153)^{\star \star \star}$ & $(2.142)^{\star \star \star}$ \\
\hline \multirow[t]{2}{*}{ Social Security expectations } & & & & & & & & 0.126 & 0.120 & 0.114 \\
\hline & & & & & & & & $(0.028)^{\star \star \star}$ & $(0.027)^{\star \star \star}$ & $(0.027)^{\star \star \star}$ \\
\hline \multirow[t]{2}{*}{ Age 45 to 49} & & & & & & & & & & -39.079 \\
\hline & & & & & & & & & & $(3.861)^{\star \star \star}$ \\
\hline \multirow[t]{2}{*}{ Age 50 to 54} & & & & & & & & & & -40.278 \\
\hline & & & & & & & & & & $(3.935)^{\star \star \star}$ \\
\hline \multirow[t]{2}{*}{ Age 55 to 59} & & & & & & & & & & -43.948 \\
\hline & & & & & & & & & & $(4.025)^{\star \star \star}$ \\
\hline \multirow[t]{2}{*}{ Age 60 to 64} & & & & & & & & & & -43.941 \\
\hline & & & & & & & & & & $(4.344)^{\star \star \star}$ \\
\hline \multirow[t]{2}{*}{ Age 65 to 69} & & & & & & & & & & -45.319 \\
\hline & & & & & & & & & & $(7.776)^{\star \star \star}$ \\
\hline \multirow[t]{2}{*}{ Male } & 7.208 & 6.921 & 7.030 & 7.249 & 6.962 & 7.277 & 6.532 & 6.928 & 6.065 & 6.060 \\
\hline & $(1.490)^{\star \star \star}$ & $(1.497)^{\star \star \star}$ & $(1.488)^{\star \star \star}$ & $(1.492)^{\star \star \star}$ & $(1.504)^{\star \star \star}$ & $(1.496)^{\star \star \star}$ & $(1.473)^{\star \star \star}$ & $(1.483)^{\star \star \star}$ & $(1.488)^{\star \star \star}$ & $(1.489)^{\star \star \star}$ \\
\hline
\end{tabular}




\begin{tabular}{|c|c|c|c|c|c|c|c|c|c|c|}
\hline & (1) & (2) & (3) & (4) & (5) & (6) & (7) & (8) & (9) & (10) \\
\hline VARIABLES & \multicolumn{10}{|c|}{ Probability Working Full-Time After 65} \\
\hline \multirow[t]{2}{*}{ Married } & -9.484 & -9.714 & -9.930 & -9.707 & -10.060 & -9.537 & -9.697 & -10.186 & -10.940 & -10.718 \\
\hline & $(1.995)^{\star \star \star}$ & $(2.005)^{\star \star \star}$ & $(1.992)^{\star \star \star}$ & $(2.002)^{\star \star \star}$ & $(1.999)^{\star \star \star}$ & $(1.997)^{\star \star \star}$ & $(1.949)^{\star \star \star}$ & $(1.980)^{\star \star \star}$ & $(1.940)^{\star \star \star}$ & $(1.933)^{\star \star \star}$ \\
\hline \multirow[t]{2}{*}{ Divorced } & 3.015 & 3.010 & 2.957 & 2.947 & 2.957 & 3.086 & 3.020 & 2.613 & 2.532 & 2.967 \\
\hline & $(2.455)$ & (2.449) & $(2.445)$ & (2.454) & $(2.443)$ & (2.459) & (2.397) & (2.442) & (2.379) & (2.386) \\
\hline \multirow[t]{2}{*}{ High school graduate } & 6.890 & 6.410 & 6.277 & 6.471 & 6.035 & 6.869 & 5.769 & 7.208 & 5.243 & 5.340 \\
\hline & $(3.027)^{\star \star}$ & $(3.037)^{\star \star}$ & $(3.034)^{\star \star}$ & $(3.034)^{\star \star}$ & $(3.041)^{\star \star}$ & $(3.020)^{\star \star}$ & $(2.977)^{\star}$ & $(3.038)^{\star \star}$ & $(2.992)^{\star}$ & $(2.988)^{\star}$ \\
\hline \multirow[t]{2}{*}{ At least some college } & 9.443 & 8.920 & 8.741 & 8.928 & 8.424 & 9.027 & 7.685 & 9.271 & 6.276 & 6.529 \\
\hline & $(2.857)^{\star \star \star}$ & $(2.861)^{\star \star \star}$ & $(2.867)^{\star \star \star}$ & $(2.865)^{\star \star \star}$ & $(2.870)^{\star \star \star}$ & $(2.852)^{\star \star \star}$ & $(2.808)^{\star \star \star}$ & $(2.867)^{\star \star \star}$ & $(2.829)^{\star \star}$ & $(2.831)^{\star \star}$ \\
\hline \multirow[t]{2}{*}{ College_graduate } & 12.123 & 11.187 & 11.313 & 11.370 & 10.768 & 11.558 & 9.284 & 11.888 & 7.375 & 7.679 \\
\hline & $(2.934)^{\star \star \star}$ & $(2.971)^{\star \star \star}$ & $(2.950)^{\star \star \star}$ & $(2.960)^{\star \star \star}$ & $(2.980)^{\star \star \star}$ & $(2.935)^{\star \star \star}$ & $(2.900)^{\star \star \star}$ & $(2.935)^{\star \star \star}$ & $(2.945)^{\star \star}$ & $(2.949)^{\star \star \star}$ \\
\hline \multirow[t]{2}{*}{ Middle wealth } & -2.015 & -2.303 & -2.489 & -2.363 & -2.657 & -2.012 & -2.424 & -2.308 & -3.254 & -3.041 \\
\hline & (1.799) & $(1.801)$ & (1.803) & (1.813) & $(1.811)$ & (1.799) & $(1.762)$ & (1.788) & $(1.760)^{\star}$ & $(1.759)^{\star}$ \\
\hline \multirow[t]{2}{*}{ High wealth } & -6.541 & -6.937 & -7.350 & -6.947 & -7.554 & -6.471 & -7.282 & -7.083 & -8.645 & -8.041 \\
\hline & $(1.965)^{\star \star \star}$ & $(1.980)^{\star \star \star}$ & $(1.970)^{\star \star \star}$ & $(1.976)^{\star \star \star}$ & $(1.982)^{\star \star \star}$ & $(1.968)^{\star \star \star}$ & $(1.936)^{\star \star \star}$ & $(1.963)^{\star \star \star}$ & $(1.952)^{\star \star \star}$ & $(1.954)^{\star \star \star}$ \\
\hline \multirow[t]{2}{*}{$\begin{array}{l}\text { Excellent or very good } \\
\text { health }\end{array}$} & 2.757 & 2.798 & & 2.735 & & & 0.533 & 2.822 & 0.721 & 0.847 \\
\hline & $(1.654)^{\star}$ & $(1.655)^{\star}$ & $(1.653)^{\star}$ & $(1.657)^{\star}$ & $(1.655)^{\star}$ & $(1.658)$ & $(1.649)$ & $\begin{array}{c}2.8 \angle 2 \\
(1.648)^{\star}\end{array}$ & $\begin{array}{l}0.121 \\
(1.644)\end{array}$ & $(1.642)$ \\
\hline \multirow[t]{2}{*}{ Fair or poor health } & -10.618 & -10.580 & -10.524 & -10.699 & -10.518 & -10.346 & -8.638 & -10.962 & -8.667 & -8.540 \\
\hline & $(2.453)^{\star \star \star}$ & $(2.449)^{\star \star \star}$ & $(2.452)^{\star \star \star}$ & $(2.453)^{\star \star \star}$ & $(2.452)^{\star \star \star}$ & $(2.463)^{\star \star \star}$ & $(2.392)^{\star \star \star}$ & $(2.438)^{\star \star \star}$ & $(2.383)^{\star \star \star}$ & $(2.377)^{\star \star \star}$ \\
\hline \multirow{2}{*}{$\begin{array}{l}\text { Missing indicator: Cognitive } \\
\text { abilities }\end{array}$} & & 33.402 & 57.586 & 33.372 & 73.049 & & & & 58.692 & 63.533 \\
\hline & & $(19.354)^{\star}$ & $(18.796)^{\star \star \star}$ & $(18.872)^{\star}$ & $(24.494)^{\star \star \star}$ & & & & $(24.655)^{\star \star}$ & $(24.584)^{\star \star \star}$ \\
\hline \multirow[t]{2}{*}{$\begin{array}{l}\text { Missing indicator: Future } \\
\text { time perspective }\end{array}$} & & & & & & 8.297 & & & 6.735 & 6.078 \\
\hline & & & & & & $(5.150)$ & & & $(5.032)$ & $(5.040)$ \\
\hline \multicolumn{11}{|l|}{ Missing indicator: Social } \\
\hline \multirow[t]{2}{*}{ Security expectations } & & & & & & & & -19.846 & -12.268 & -12.778 \\
\hline & & & & & & & & $(4.793)^{\star \star \star}$ & $(2.666)^{\star \star \star}$ & $(2.966)^{\star \star \star}$ \\
\hline \multirow[t]{2}{*}{ Missing indicator: Wealth } & -0.338 & -0.575 & -0.225 & -0.116 & -0.389 & -1.009 & -0.551 & -0.932 & -1.593 & -0.794 \\
\hline & $(6.228)$ & $(6.234)$ & $(6.113)$ & (6.182) & $(6.115)$ & $(6.336)$ & $(5.908)$ & $(6.292)$ & $(5.996)$ & $(5.905)$ \\
\hline
\end{tabular}




\begin{tabular}{|c|c|c|c|c|c|c|c|c|c|c|}
\hline & (1) & (2) & (3) & (4) & (5) & (6) & (7) & (8) & (9) & (10) \\
\hline VARIABLES & \multicolumn{10}{|c|}{ Probability Working Full-Time After 65} \\
\hline Constant & $\begin{array}{c}37.426 \\
(3.024)^{\star \star \star}\end{array}$ & $\begin{array}{c}6.601 \\
(18.842)\end{array}$ & $\begin{array}{c}-17.306 \\
(18.468)\end{array}$ & $\begin{array}{c}6.474 \\
(18.442)\end{array}$ & $\begin{array}{l}-32.178 \\
(23.878)\end{array}$ & $\begin{array}{c}27.567 \\
(5.572)^{\star \star \star}\end{array}$ & $\begin{array}{c}26.034 \\
(3.190)^{\star \star \star}\end{array}$ & $\begin{array}{c}30.395 \\
(3.442)^{\star \star \star}\end{array}$ & $\begin{array}{c}-44.308 \\
(24.405)^{\star}\end{array}$ & $\begin{array}{c}-7.429 \\
(23.478)\end{array}$ \\
\hline Observations & 2,056 & 2,056 & 2,056 & 2,056 & 2,056 & 2,056 & 2,056 & 2,056 & 2,056 & 2,056 \\
\hline
\end{tabular}

NOTE: Numbers reported are regression coefficients, with standard errors in parentheses. 
Table B2c. Expectation of Working Full-time After Age 65 (P65)

\begin{tabular}{|c|c|c|c|c|c|c|}
\hline \multirow[b]{2}{*}{ VARIABLES } & (1) & (2) & (3) & (4) & (5) & (6) \\
\hline & \multicolumn{6}{|c|}{ Probability Working Full-Time After 65} \\
\hline \multirow[t]{2}{*}{ Financial literacy index } & 0.313 & -0.152 & -0.036 & & & \\
\hline & $(0.555)$ & $(0.655)$ & $(0.662)$ & & & \\
\hline \multirow[t]{2}{*}{$\begin{array}{l}\text { Maximizing: having high } \\
\text { standards }\end{array}$} & & & & -1.494 & -2.035 & -2.053 \\
\hline & & & & $(0.944)$ & $(0.933)^{\star \star}$ & $(0.929)^{\star \star}$ \\
\hline \multirow[t]{2}{*}{ Maximizing: continual search } & & & & 2.571 & 1.601 & 1.384 \\
\hline & & & & $(0.990)^{\star \star \star}$ & $(0.992)$ & $(1.000)$ \\
\hline \multirow[t]{2}{*}{ Maximizing: decision difficulty } & & & & -1.151 & -0.498 & -0.419 \\
\hline & & & & $(0.828)$ & $(0.825)$ & $(0.827)$ \\
\hline \multirow[t]{2}{*}{ Age 45 to 49} & & & 4.684 & & & 6.762 \\
\hline & & & $(2.776)^{\star}$ & & & $(2.920)^{\star \star}$ \\
\hline \multirow[t]{2}{*}{ Age 50 to 54} & & & 4.219 & & & 4.010 \\
\hline & & & $(2.756)$ & & & $(2.886)$ \\
\hline \multirow[t]{2}{*}{ Age 55 to 59} & & & 1.893 & & & 0.426 \\
\hline & & & $(2.779)$ & & & $(2.879)$ \\
\hline \multirow[t]{2}{*}{ Age 65 to 69} & & & -0.335 & & & 0.639 \\
\hline & & & (7.671) & & & $(7.554)$ \\
\hline \multirow[t]{2}{*}{ Male } & & 8.430 & 8.421 & & 7.346 & 7.308 \\
\hline & & $(1.922)^{\star \star \star}$ & $(1.925)^{\star \star \star}$ & & $(1.981)^{\star \star \star}$ & $(1.982)^{\star \star \star}$ \\
\hline \multirow[t]{2}{*}{ Married } & & -10.743 & -10.494 & & -7.796 & -7.365 \\
\hline & & $(2.658)^{\star \star \star}$ & $(2.656)^{\star \star \star}$ & & $(2.814)^{\star \star \star}$ & $(2.813)^{\star \star \star}$ \\
\hline \multirow[t]{2}{*}{ Divorced } & & 3.870 & 4.349 & & 5.516 & 6.248 \\
\hline & & (3.187) & (3.201) & & (3.396) & $(3.412)^{\star}$ \\
\hline \multirow[t]{2}{*}{ High school graduate } & & 13.099 & 13.337 & & 15.112 & 15.599 \\
\hline & & $(4.060)^{\star \star \star}$ & $(4.066)^{\star \star \star}$ & & $(4.146)^{\star \star \star}$ & $(4.156)^{\star \star \star}$ \\
\hline \multirow[t]{2}{*}{ At least some college } & & 15.108 & 15.340 & & 15.472 & 16.215 \\
\hline & & $(3.913)^{\star \star \star}$ & $(3.930)^{\star \star \star}$ & & $(3.912)^{\star \star \star}$ & $(3.947)^{\star \star \star}$ \\
\hline \multirow[t]{2}{*}{ College_graduate } & & 17.731 & 17.891 & & 18.295 & 19.071 \\
\hline & & $(4.094)^{\star \star \star}$ & $(4.107)^{\star \star \star}$ & & $(3.965)^{\star \star \star}$ & $(4.001)^{\star \star \star}$ \\
\hline \multirow[t]{2}{*}{ Middle wealth } & & -3.082 & -2.800 & & -3.625 & -3.304 \\
\hline & & $(2.301)$ & (2.297) & & $(2.450)$ & $(2.444)$ \\
\hline \multirow[t]{2}{*}{ High wealth } & & -9.641 & -8.995 & & -9.292 & -8.414 \\
\hline & & $(2.488)^{\star \star \star}$ & $(2.486)^{\star \star \star}$ & & $(2.497)^{\star \star \star}$ & $(2.498)^{\star \star \star}$ \\
\hline \multirow[t]{2}{*}{ Excellent or very good health } & & 2.694 & 2.708 & & 4.815 & 4.817 \\
\hline & & $(2.043)$ & (2.042) & & $(2.166)^{\star \star}$ & $(2.159)^{\star \star}$ \\
\hline \multirow[t]{2}{*}{ Fair or poor health } & & -13.566 & -13.396 & & -11.730 & -11.596 \\
\hline & & $(3.355)^{\star \star \star}$ & $(3.355)^{\star \star \star}$ & & $(3.570)^{\star \star \star}$ & $(3.549)^{\star \star \star}$ \\
\hline \multirow[t]{2}{*}{ Missing indicator: Wealth } & & -7.459 & -7.087 & & -7.881 & -7.016 \\
\hline & & $(8.150)$ & $(8.013)$ & & $(7.761)$ & $(7.677)$ \\
\hline \multirow[t]{2}{*}{ Constant } & 42.177 & 34.265 & 30.674 & 44.349 & 36.031 & 32.224 \\
\hline & $(0.950)^{\star \star \star}$ & $(4.488)^{\star \star \star}$ & $(5.044)^{\star \star \star}$ & $(5.520)^{\star \star \star}$ & $(6.582)^{\star \star \star}$ & $(7.048)^{\star \star \star}$ \\
\hline
\end{tabular}


(1) (2) (3) (4) (5)

Probability Working Full-Time After 65

VARIABLES

$1,339 \quad 1,339$

1,229

1,229

1,229

1,339

* Two-sided $p$-value $<.10 ; * \star p<.05 ; * \star \star ~ p<.01$.

NOTE: Numbers reported are regression coefficients, with standard errors in parentheses. 
Table B3a. Planning to Retire Late (P65 > 80\%)

\begin{tabular}{|c|c|c|c|c|c|c|c|c|}
\hline \multirow[b]{2}{*}{ VARIABLES } & (1) & (2) & (3) & (4) & (5) & (6) & (7) & (8) \\
\hline & \multicolumn{8}{|c|}{ Plans to Retire Late $(\mathrm{P} 65>\mathbf{8 0})$} \\
\hline \multirow[t]{2}{*}{ Cognitive ability: Number series } & 0.001 & & & 0.000 & & & & -0.000 \\
\hline & $(0.000)^{*}$ & & & $(0.000)$ & & & & $(0.000)$ \\
\hline \multirow[t]{2}{*}{ Cognitive ability: Picture vocabulary } & & 0.001 & & 0.001 & & & & 0.001 \\
\hline & & $(0.000)^{\star \star \star}$ & & $(0.000)^{\star \star \star}$ & & & & $(0.000)^{\star \star \star}$ \\
\hline \multirow[t]{2}{*}{ Cognitive ability: Verbal analogies } & & & 0.000 & -0.000 & & & & -0.000 \\
\hline & & & $(0.000)$ & $(0.000)$ & & & & $(0.000)$ \\
\hline \multirow[t]{2}{*}{ Focus on opportunities } & & & & & 0.008 & & & 0.003 \\
\hline & & & & & $(0.008)$ & & & $(0.008)$ \\
\hline \multirow[t]{2}{*}{ Focus on limitations } & & & & & 0.014 & & & 0.016 \\
\hline & & & & & $(0.008)^{*}$ & & & $(0.008)^{\star *}$ \\
\hline \multirow[t]{2}{*}{ Longevity ratio } & & & & & & 0.155 & & 0.157 \\
\hline & & & & & & $(0.022)^{\star \star \star}$ & & $(0.022)^{\star \star \star}$ \\
\hline \multirow[t]{2}{*}{ Social Security expectations } & & & & & & & 0.001 & 0.001 \\
\hline & & & & & & & $(0.000)^{\star \star *}$ & $(0.000)^{\star \star \star}$ \\
\hline \multirow[t]{2}{*}{ Missing indicator: Cognitive abilities } & 0.315 & 0.762 & 0.225 & 0.781 & & & & 0.457 \\
\hline & $(0.181)^{\star}$ & $(0.190)^{\star \star \star}$ & $(0.187)$ & $(0.229)^{\star \star \star}$ & & & & $(0.233)^{\star}$ \\
\hline \multirow[t]{2}{*}{ Missing indicator: Future time perspective } & & & & & 0.068 & & & 0.056 \\
\hline & & & & & $(0.059)$ & & & $(0.058)$ \\
\hline \multirow[t]{2}{*}{$\begin{array}{l}\text { Missing indicator: Social Security } \\
\text { expectations }\end{array}$} & & & & & & & -0.082 & -0.026 \\
\hline & & & & & & & $(0.020)^{\star \star \star}$ & $(0.052)$ \\
\hline \multirow[t]{2}{*}{ Constant } & -0.176 & -0.623 & -0.086 & -0.642 & 0.062 & 0.020 & 0.082 & -0.571 \\
\hline & $(0.180)$ & $(0.189)^{\star \star \star}$ & $(0.186)$ & $(0.228)^{\star \star \star}$ & $(0.056)$ & $(0.017)$ & $(0.020)^{\star * *}$ & $(0.234)^{\star *}$ \\
\hline Observations & 2,056 & 2,056 & 2,056 & 2,056 & 2,056 & 2,056 & 2,056 & 2,056 \\
\hline
\end{tabular}

* Two-sided $p$-value <.10; ** $p<.05$; *** $p<.01$

NOTE: Numbers reported are regression coefficients, with standard errors in parentheses. 
Table B3b. Planning to Retire Late (P65 > 80\%)

\begin{tabular}{|c|c|c|c|c|c|c|c|c|c|c|}
\hline \multirow[b]{2}{*}{ VARIABLES } & (1) & (2) & (3) & (4) & (5) & (6) & (7) & (8) & (9) & (10) \\
\hline & \multicolumn{10}{|c|}{ Plans to Retire Late (P65 > 80) } \\
\hline \multirow[t]{2}{*}{ Cognitive ability: Number series } & & 0.000 & & & 0.000 & & & & -0.000 & -0.000 \\
\hline & & $(0.000)$ & & & $(0.000)$ & & & & $(0.000)$ & $(0.000)$ \\
\hline \multirow[t]{2}{*}{ Cognitive ability: Picture vocabulary } & & & 0.001 & & 0.001 & & & & 0.001 & 0.001 \\
\hline & & & $(0.000)^{\star \star \star}$ & & $(0.000)^{\star \star \star}$ & & & & $(0.000)^{\star \star \star}$ & $(0.000)^{\star \star *}$ \\
\hline \multirow[t]{2}{*}{ Cognitive ability: Verbal analogies } & & & & 0.000 & -0.000 & & & & -0.000 & -0.000 \\
\hline & & & & $(0.000)$ & $(0.000)$ & & & & $(0.000)$ & $(0.000)$ \\
\hline \multirow[t]{2}{*}{ Focus on opportunities } & & & & & & 0.002 & & & -0.001 & 0.002 \\
\hline & & & & & & $(0.008)$ & & & $(0.008)$ & $(0.008)$ \\
\hline \multirow[t]{2}{*}{ Focus on limitations } & & & & & & 0.014 & & & 0.015 & 0.013 \\
\hline & & & & & & $(0.008)^{\star}$ & & & $(0.008)^{\star}$ & $(0.008)^{\star}$ \\
\hline \multirow[t]{2}{*}{ Longevity ratio } & & & & & & & 0.135 & & 0.142 & 0.142 \\
\hline & & & & & & & $(0.023)^{\star \star \star}$ & & $(0.023)^{\star \star \star}$ & $(0.023)^{\star \star \star}$ \\
\hline \multirow[t]{2}{*}{ Social Security expectations } & & & & & & & & 0.001 & 0.001 & 0.001 \\
\hline & & & & & & & & $(0.000)^{\star \star \star}$ & $(0.000)^{\star \star \star}$ & $(0.000)^{\star \star \star}$ \\
\hline \multirow[t]{2}{*}{ Age 45 to 49} & & & & & & & & & & -0.842 \\
\hline & & & & & & & & & & $(0.041)^{\star \star \star}$ \\
\hline \multirow[t]{2}{*}{ Age 50 to 54} & & & & & & & & & & -0.831 \\
\hline & & & & & & & & & & $(0.043)^{\star \star \star}$ \\
\hline \multirow[t]{2}{*}{ Age 55 to 59} & & & & & & & & & & -0.835 \\
\hline & & & & & & & & & & $(0.044)^{\star \star \star}$ \\
\hline \multirow[t]{2}{*}{ Age 60 to 64} & & & & & & & & & & -0.768 \\
\hline & & & & & & & & & & $(0.047)^{\star \star \star}$ \\
\hline \multirow[t]{2}{*}{ Age 65 to 69} & & & & & & & & & & -0.711 \\
\hline & & & & & & & & & & $(0.088)^{\star \star \star}$ \\
\hline \multirow[t]{2}{*}{ Male } & 0.042 & 0.040 & 0.040 & 0.043 & 0.039 & 0.041 & 0.037 & 0.039 & 0.031 & 0.029 \\
\hline & $(0.016)^{\star \star \star}$ & $(0.016)^{\star \star}$ & $(0.016)^{\star \star}$ & $(0.016)^{\star \star \star}$ & $(0.016)^{\star \star}$ & $(0.016)^{\star \star}$ & $(0.016)^{\star \star}$ & $(0.016)^{\star \star}$ & $(0.016)^{\star}$ & $(0.016)^{\star}$ \\
\hline \multirow[t]{2}{*}{ Married } & -0.079 & -0.081 & -0.086 & -0.080 & -0.086 & -0.081 & -0.080 & -0.085 & -0.094 & -0.094 \\
\hline & $(0.022)^{\star \star \star}$ & $(0.022)^{\star \star \star}$ & $(0.022)^{\star \star \star}$ & $(0.022)^{\star \star \star}$ & $(0.022)^{\star \star \star}$ & $(0.022)^{\star \star \star}$ & $(0.022)^{\star \star \star}$ & $(0.022)^{\star \star \star}$ & $(0.022)^{\star \star \star}$ & $(0.022)^{\star \star \star}$ \\
\hline
\end{tabular}




\begin{tabular}{|c|c|c|c|c|c|c|c|c|c|c|}
\hline \multirow[b]{2}{*}{ VARIABLES } & (1) & (2) & (3) & (4) & (5) & (6) & (7) & (8) & (9) & (10) \\
\hline & \multicolumn{10}{|c|}{ Plans to Retire Late $(P 65>80)$} \\
\hline \multirow[t]{2}{*}{ Divorced } & -0.009 & -0.008 & -0.009 & -0.009 & -0.009 & -0.010 & -0.009 & -0.012 & -0.014 & -0.016 \\
\hline & $(0.028)$ & $(0.028)$ & $(0.028)$ & $(0.028)$ & $(0.028)$ & $(0.028)$ & $(0.028)$ & $(0.028)$ & $(0.028)$ & $(0.028)$ \\
\hline \multirow[t]{2}{*}{ High school graduate } & 0.028 & 0.025 & 0.020 & 0.026 & 0.020 & 0.027 & 0.020 & 0.031 & 0.014 & 0.010 \\
\hline & $(0.029)$ & $(0.029)$ & $(0.029)$ & $(0.029)$ & $(0.029)$ & $(0.028)$ & $(0.028)$ & $(0.029)$ & $(0.028)$ & $(0.029)$ \\
\hline \multirow[t]{2}{*}{ At least some college } & 0.074 & 0.070 & 0.063 & 0.071 & 0.064 & 0.071 & 0.061 & 0.073 & 0.048 & 0.041 \\
\hline & $(0.028)^{\star \star \star}$ & $(0.028)^{\star \star}$ & $(0.028)^{\star \star}$ & $(0.028)^{\star \star}$ & $(0.028)^{\star \star}$ & $(0.028)^{\star \star}$ & $(0.028)^{\star \star}$ & $(0.028)^{\star \star \star}$ & $(0.028)^{\star}$ & $(0.028)$ \\
\hline \multirow[t]{2}{*}{ College_graduate } & 0.096 & 0.089 & 0.083 & 0.091 & 0.085 & 0.090 & 0.075 & 0.094 & 0.059 & 0.051 \\
\hline & $(0.029)^{\star \star \star}$ & $(0.029)^{\star \star \star}$ & $(0.029)^{\star \star \star}$ & $(0.029)^{\star \star \star}$ & $(0.029)^{\star \star \star}$ & $(0.029)^{\star \star \star}$ & $(0.029)^{\star \star \star}$ & $(0.029)^{\star \star \star}$ & $(0.029)^{\star \star}$ & $(0.029)^{\star}$ \\
\hline \multirow[t]{2}{*}{ Middle wealth } & -0.033 & -0.035 & -0.040 & -0.035 & -0.039 & -0.034 & -0.036 & -0.035 & -0.044 & -0.049 \\
\hline & $(0.020)^{\star}$ & $(0.020)^{\star}$ & $(0.020)^{\star \star}$ & $(0.020)^{\star}$ & $(0.020)^{\star \star}$ & $(0.020)^{\star}$ & $(0.019)^{\star}$ & $(0.019)^{\star}$ & $(0.019)^{\star \star}$ & $(0.019)^{\star \star}$ \\
\hline \multirow[t]{2}{*}{ High wealth } & -0.036 & -0.040 & -0.049 & -0.039 & -0.048 & -0.038 & -0.042 & -0.041 & -0.058 & -0.065 \\
\hline & $(0.022)^{\star}$ & $(0.022)^{\star}$ & $(0.022)^{\star \star}$ & $(0.022)^{\star}$ & $(0.022)^{\star \star}$ & $(0.022)^{\star}$ & $(0.021)^{\star \star}$ & $(0.022)^{\star}$ & $(0.022)^{\star \star \star}$ & $(0.022)^{\star \star \star}$ \\
\hline \multirow[t]{2}{*}{ Excellent or very good health } & 0.047 & 0.046 & 0.047 & 0.046 & 0.047 & 0.049 & 0.030 & 0.047 & 0.035 & 0.034 \\
\hline & $(0.018)^{\star \star \star}$ & $(0.018)^{\star \star \star}$ & $(0.018)^{\star \star \star}$ & $(0.018)^{\star \star \star}$ & $(0.018)^{\star \star \star}$ & $(0.018)^{\star \star \star}$ & $(0.018)^{\star}$ & $(0.018)^{\star \star \star}$ & $(0.018)^{\star}$ & $(0.018)^{\star}$ \\
\hline \multirow[t]{2}{*}{ Fair or poor health } & -0.049 & -0.049 & -0.047 & -0.049 & -0.047 & -0.050 & -0.035 & -0.052 & -0.035 & -0.033 \\
\hline & $(0.023)^{\star \star}$ & $(0.023)^{\star \star}$ & $(0.023)^{\star \star}$ & $(0.023)^{\star \star}$ & $(0.023)^{\star \star}$ & $(0.023)^{\star \star}$ & $(0.023)$ & $(0.023)^{\star \star}$ & $(0.023)$ & $(0.023)$ \\
\hline \multirow[t]{2}{*}{ Missing indicator: Cognitive abilities } & & 0.207 & 0.790 & 0.177 & 0.745 & & & & 0.573 & 0.592 \\
\hline & & $(0.198)$ & $(0.197)^{\star \star \star}$ & $(0.200)$ & $(0.251)^{\star \star \star}$ & & & & $(0.253)^{\star \star}$ & $(0.253)^{\star \star}$ \\
\hline \multirow{2}{*}{$\begin{array}{l}\text { Missing indicator: Future time } \\
\text { perspective }\end{array}$} & & & & & & 0.040 & & & 0.035 & 0.041 \\
\hline & & & & & & $(0.058)$ & & & $(0.057)$ & $(0.057)$ \\
\hline \multirow[t]{2}{*}{$\begin{array}{l}\text { Missing indicator: Social Security } \\
\text { expectations }\end{array}$} & & & & & & & & -0.067 & -0.011 & 0.002 \\
\hline & & & & & & & & $(0.022)^{\star \star \star}$ & $(0.048)$ & $(0.047)$ \\
\hline \multirow[t]{2}{*}{ Missing indicator: Wealth } & -0.061 & -0.065 & -0.063 & -0.062 & -0.064 & -0.065 & -0.063 & -0.067 & -0.072 & -0.081 \\
\hline & $(0.062)$ & $(0.061)$ & $(0.061)$ & $(0.061)$ & $(0.061)$ & $(0.062)$ & $(0.059)$ & $(0.063)$ & $(0.060)$ & $(0.062)$ \\
\hline \multirow[t]{2}{*}{ Constant } & 0.117 & -0.091 & -0.662 & -0.062 & -0.618 & 0.063 & 0.032 & 0.055 & -0.638 & 0.171 \\
\hline & $(0.030)^{\star \star \star}$ & $(0.192)$ & $(0.193)^{\star \star \star}$ & $(0.194)$ & $(0.244)^{\star \star}$ & $(0.061)$ & $(0.031)$ & $(0.035)$ & $(0.249)^{\star \star}$ & $(0.244)$ \\
\hline Observations & 2,056 & 2,056 & 2,056 & 2,056 & 2,056 & 2,056 & 2,056 & 2,056 & 2,056 & 2,056 \\
\hline
\end{tabular}

* Two-sided p-value $<10$; ** $p<.05$; *** $p<.01$

NOTE: Numbers reported are regression coefficients, with standard errors in parentheses. 
Table B3c. Planning to Retire Late (P65 > 80\%)

\begin{tabular}{|c|c|c|c|c|c|c|}
\hline \multirow[b]{2}{*}{ VARIABLES } & (1) & (2) & (3) & (4) & (5) & (6) \\
\hline & \multicolumn{6}{|c|}{ Plans to Retire Late (P65 > 80) } \\
\hline \multirow[t]{2}{*}{ Financial literacy index } & 0.008 & 0.003 & 0.001 & & & \\
\hline & $(0.006)$ & $(0.007)$ & $(0.007)$ & & & \\
\hline \multirow[t]{2}{*}{$\begin{array}{l}\text { Maximizing: having high } \\
\text { standards }\end{array}$} & & & & -0.014 & -0.019 & -0.018 \\
\hline & & & & $(0.010)$ & $(0.010)^{*}$ & $(0.010)^{*}$ \\
\hline \multirow[t]{2}{*}{ Maximizing: continual search } & & & & -0.005 & -0.010 & -0.009 \\
\hline & & & & $(0.011)$ & $(0.011)$ & $(0.011)$ \\
\hline \multirow[t]{2}{*}{ Maximizing: decision difficulty } & & & & -0.013 & -0.008 & -0.008 \\
\hline & & & & $(0.009)$ & $(0.009)$ & $(0.009)$ \\
\hline \multirow[t]{2}{*}{ Age 45 to 49} & & & -0.071 & & & -0.055 \\
\hline & & & $(0.030)^{\star \star}$ & & & $(0.031)^{\star}$ \\
\hline \multirow[t]{2}{*}{ Age 50 to 54} & & & -0.044 & & & -0.046 \\
\hline & & & $(0.030)$ & & & $(0.031)$ \\
\hline \multirow[t]{2}{*}{ Age 55 to 59} & & & -0.037 & & & -0.050 \\
\hline & & & $(0.030)$ & & & $(0.031)$ \\
\hline \multirow[t]{2}{*}{ Age 65 to 69} & & & 0.090 & & & 0.093 \\
\hline & & & $(0.087)$ & & & $(0.086)$ \\
\hline \multirow[t]{2}{*}{ Male } & & 0.041 & 0.039 & & 0.042 & 0.038 \\
\hline & & $(0.021)^{\star}$ & $(0.021)^{\star}$ & & $(0.021)^{\star \star}$ & $(0.021)^{\star}$ \\
\hline \multirow[t]{2}{*}{ Married } & & -0.065 & -0.068 & & -0.030 & -0.033 \\
\hline & & $(0.030)^{\star \star}$ & $(0.029)^{\star \star}$ & & $(0.029)$ & $(0.029)$ \\
\hline \multirow[t]{2}{*}{ Divorced } & & 0.012 & 0.005 & & 0.036 & 0.029 \\
\hline & & $(0.037)$ & $(0.037)$ & & $(0.038)$ & $(0.038)$ \\
\hline \multirow[t]{2}{*}{ High school graduate } & & 0.117 & 0.115 & & 0.119 & 0.113 \\
\hline & & $(0.029)^{\star \star \star}$ & $(0.029)^{\star \star \star}$ & & $(0.031)^{\star \star \star}$ & $(0.031)^{\star \star *}$ \\
\hline \multirow[t]{2}{*}{ At least some college } & & 0.139 & 0.135 & & 0.130 & 0.123 \\
\hline & & $(0.027)^{\star \star \star}$ & $(0.027)^{\star \star \star}$ & & $(0.029)^{\star \star \star}$ & $(0.029)^{\star \star \star}$ \\
\hline \multirow[t]{2}{*}{ College_graduate } & & 0.168 & 0.164 & & 0.151 & 0.143 \\
\hline & & $(0.029)^{\star \star \star}$ & $(0.030)^{\star \star \star}$ & & $(0.030)^{\star \star \star}$ & $(0.030)^{\star \star \star}$ \\
\hline \multirow[t]{2}{*}{ Middle wealth } & & -0.041 & -0.045 & & -0.034 & -0.036 \\
\hline & & $(0.026)$ & $(0.026)^{\star}$ & & $(0.027)$ & $(0.027)$ \\
\hline \multirow[t]{2}{*}{ High wealth } & & -0.066 & -0.074 & & -0.061 & -0.066 \\
\hline & & $(0.028)^{\star \star}$ & $(0.028)^{\star \star \star}$ & & $(0.028)^{\star \star}$ & $(0.027)^{\star \star}$ \\
\hline \multirow[t]{2}{*}{ Excellent or very good health } & & 0.032 & 0.032 & & 0.044 & 0.045 \\
\hline & & $(0.022)$ & $(0.022)$ & & $(0.023)^{\star}$ & $(0.023)^{\star \star}$ \\
\hline \multirow[t]{2}{*}{ Fair or poor health } & & -0.049 & -0.049 & & -0.052 & -0.049 \\
\hline & & $(0.032)$ & $(0.032)$ & & $(0.032)$ & $(0.032)$ \\
\hline \multirow[t]{2}{*}{ Missing indicator: Wealth } & & -0.082 & -0.086 & & -0.077 & -0.080 \\
\hline & & $(0.079)$ & $(0.079)$ & & $(0.073)$ & $(0.075)$ \\
\hline \multirow[t]{2}{*}{ Constant } & 0.152 & 0.060 & 0.109 & 0.279 & 0.179 & 0.219 \\
\hline & $(0.010)^{\star \star \star}$ & $(0.037)^{\star}$ & $(0.044)^{\star \star}$ & $(0.060)^{\star \star \star}$ & $(0.065)^{\star \star \star}$ & $(0.071)^{\star \star \star}$ \\
\hline
\end{tabular}




$\begin{array}{ll}\text { (1) (2) } & \text { (3) (4) } \\ \text { Plans to Retire Late (P65 > 80) }\end{array}$

VARIABLES

Plans to Retire Late (P65 > 80)

Observations

1,339

$1,339 \quad 1,339$

1,229

1,229

1,229

* Two-sided $p$-value <.10; ** $p<.05 ;{ }^{* \star \star} p<.01$.

NOTE: Numbers reported are regression coefficients, with standard errors in parentheses. 
Table B4a. Planning to Retire Early (P62 < 20\%)

\begin{tabular}{|c|c|c|c|c|c|c|c|c|}
\hline \multirow[b]{2}{*}{ VARIABLES } & (1) & (2) & (3) & (4) & (5) & (6) & (7) & (8) \\
\hline & \multicolumn{8}{|c|}{ Plans to Retire Early (P62 < 20) } \\
\hline \multirow[t]{2}{*}{ Cognitive ability: Number series } & -0.000 & & & 0.000 & & & & 0.000 \\
\hline & $(0.000)$ & & & $(0.000)$ & & & & $(0.000)$ \\
\hline \multirow[t]{2}{*}{ Cognitive ability: Picture vocabulary } & & -0.001 & & -0.000 & & & & -0.000 \\
\hline & & $(0.000)$ & & $(0.000)$ & & & & $(0.000)$ \\
\hline \multirow[t]{2}{*}{ Cognitive ability: Verbal analogies } & & & -0.000 & -0.000 & & & & -0.000 \\
\hline & & & $(0.000)$ & $(0.001)$ & & & & $(0.001)$ \\
\hline \multirow[t]{2}{*}{ Focus on opportunities } & & & & & -0.021 & & & -0.017 \\
\hline & & & & & $(0.008)^{\star \star}$ & & & $(0.008)^{\star \star}$ \\
\hline \multirow[t]{2}{*}{ Focus on limitations } & & & & & -0.008 & & & -0.011 \\
\hline & & & & & $(0.009)$ & & & $(0.009)$ \\
\hline \multirow[t]{2}{*}{ Longevity ratio } & & & & & & -0.138 & & -0.138 \\
\hline & & & & & & $(0.028)^{\star \star \star}$ & & $(0.028)^{\star \star *}$ \\
\hline \multirow[t]{2}{*}{ Social Security expectations } & & & & & & & -0.000 & -0.000 \\
\hline & & & & & & & $(0.000)$ & $(0.000)$ \\
\hline \multirow[t]{2}{*}{ Missing indicator: Cognitive abilities } & -0.111 & -0.331 & -0.218 & -0.353 & & & & -0.173 \\
\hline & $(0.218)$ & $(0.241)$ & $(0.231)$ & $(0.293)$ & & & & $(0.294)$ \\
\hline \multirow[t]{2}{*}{$\begin{array}{l}\text { Missing indicator: Future time } \\
\text { perspective }\end{array}$} & & & & & -0.092 & & & -0.075 \\
\hline & & & & & $(0.065)$ & & & $(0.065)$ \\
\hline \multirow[t]{2}{*}{$\begin{array}{l}\text { Missing indicator: Social Security } \\
\text { expectations }\end{array}$} & & & & & & & -0.212 & -0.270 \\
\hline & & & & & & & $(0.024)^{\star \star \star}$ & $(0.049)^{\star \star \star}$ \\
\hline \multirow[t]{2}{*}{ Constant } & 0.278 & 0.497 & 0.384 & 0.519 & 0.306 & 0.306 & 0.212 & 0.569 \\
\hline & $(0.217)$ & $(0.241)^{\star \star}$ & $(0.231)^{\star}$ & $(0.292)^{\star}$ & $(0.061)^{\star \star \star}$ & $(0.026)^{\star \star \star}$ & $(0.024)^{\star \star \star}$ & $(0.297)^{\star}$ \\
\hline Observations & 1,864 & 1,864 & 1,864 & 1,864 & 1,864 & 1,864 & 1,864 & 1,864 \\
\hline
\end{tabular}

NOTE: Numbers reported are regression coefficients, with standard errors in parentheses. 
Table B4b. Planning to Retire Early (P62 < 20\%)

\begin{tabular}{|c|c|c|c|c|c|c|c|c|c|c|}
\hline \multirow[b]{2}{*}{ VARIABLES } & (1) & (2) & (3) & (4) & (5) & (6) & (7) & (8) & (9) & (10) \\
\hline & \multicolumn{10}{|c|}{ Plans to Retire Early (P62 $<20$ ) } \\
\hline \multirow[t]{2}{*}{$\begin{array}{l}\text { Cognitive ability: Number } \\
\text { series }\end{array}$} & & 0.000 & & & 0.001 & & & & 0.001 & 0.001 \\
\hline & & $(0.000)$ & & & $(0.000)$ & & & & $(0.000)$ & $(0.000)$ \\
\hline \multirow{2}{*}{$\begin{array}{l}\text { Cognitive ability: Picture } \\
\text { vocabulary }\end{array}$} & & & -0.000 & & -0.000 & & & & -0.000 & -0.001 \\
\hline & & & $(0.000)$ & & $(0.000)$ & & & & $(0.000)$ & $(0.000)$ \\
\hline \multirow[t]{2}{*}{$\begin{array}{l}\text { Cognitive ability: Verbal } \\
\text { analogies }\end{array}$} & & & & -0.000 & -0.000 & & & & -0.000 & -0.000 \\
\hline & & & & $(0.000)$ & $(0.001)$ & & & & $(0.001)$ & $(0.001)$ \\
\hline \multirow[t]{2}{*}{ Focus on opportunities } & & & & & & -0.016 & & & -0.013 & -0.009 \\
\hline & & & & & & $(0.008)^{\star \star}$ & & & $(0.008)$ & $(0.008)$ \\
\hline \multirow[t]{2}{*}{ Focus on limitations } & & & & & & -0.009 & & & -0.012 & -0.014 \\
\hline & & & & & & $(0.009)$ & & & $(0.009)$ & $(0.009)$ \\
\hline \multirow[t]{2}{*}{ Longevity ratio } & & & & & & & -0.108 & & -0.112 & -0.114 \\
\hline & & & & & & & $(0.028)^{\star \star \star}$ & & $(0.028)^{\star \star \star}$ & $(0.028)^{\star \star \star}$ \\
\hline \multirow[t]{2}{*}{ Social Security expectations } & & & & & & & & -0.000 & -0.000 & -0.000 \\
\hline & & & & & & & & $(0.000)$ & $(0.000)$ & $(0.000)$ \\
\hline \multirow[t]{2}{*}{ Age 45 to 49} & & & & & & & & & & 0.106 \\
\hline & & & & & & & & & & $(0.046)^{\star \star}$ \\
\hline \multirow[t]{2}{*}{ Age 50 to 54} & & & & & & & & & & 0.093 \\
\hline & & & & & & & & & & $(0.048)^{\star \star}$ \\
\hline \multirow[t]{2}{*}{ Age 55 to 59} & & & & & & & & & & 0.132 \\
\hline & & & & & & & & & & $(0.049)^{\star \star \star}$ \\
\hline \multirow[t]{2}{*}{ Age 60 to 64} & & & & & & & & & & 0.230 \\
\hline & & & & & & & & & & $(0.056)^{\star \star \star}$ \\
\hline \multirow[t]{2}{*}{ Male } & -0.046 & -0.046 & -0.044 & -0.045 & -0.047 & -0.047 & -0.042 & -0.045 & -0.044 & -0.046 \\
\hline & $(0.018)^{\star \star}$ & $(0.018)^{\star \star}$ & $(0.018)^{\star \star}$ & $(0.018)^{\star \star}$ & $(0.018)^{\star \star}$ & $(0.018)^{\star \star}$ & $(0.018)^{\star \star}$ & $(0.018)^{\star \star}$ & $(0.019)^{\star \star}$ & $(0.018)^{\star \star}$ \\
\hline Married & 0.064 & 0.062 & 0.065 & 0.064 & 0.064 & 0.063 & 0.066 & 0.066 & 0.069 & 0.066 \\
\hline
\end{tabular}




$\begin{array}{lllllllll}(1) & (2) & (3) & (4) & (5) & (6) & \text { (7) } & \text { (8) } & \text { (9) }\end{array}$

VARIABLES

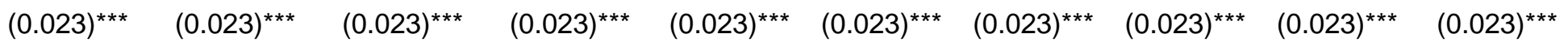

Divorced

High school graduate

$\begin{array}{cccccccccc}0.026 & 0.026 & 0.026 & 0.026 & 0.026 & 0.024 & 0.026 & 0.027 & 0.027 & 0.023 \\ (0.028) & (0.028) & (0.028) & (0.028) & (0.028) & (0.028) & (0.028) & (0.028) & (0.028) & (0.028) \\ -0.104 & -0.105 & -0.101 & -0.102 & -0.103 & -0.104 & -0.097 & -0.104 & -0.095 & -0.099 \\ (0.043)^{\star \star} & (0.043)^{\star \star} & (0.043)^{\star \star} & (0.043)^{\star \star} & (0.043)^{\star \star} & (0.043)^{\star \star} & (0.042)^{\star \star} & (0.043)^{\star \star} & (0.042)^{\star \star} & (0.042)^{\star \star} \\ -0.088 & -0.091 & -0.086 & -0.087 & -0.088 & -0.084 & -0.078 & -0.086 & -0.073 & -0.081 \\ (0.041)^{\star \star} & (0.041)^{\star \star} & (0.041)^{\star \star} & (0.041)^{\star \star} & (0.041)^{\star \star} & (0.041)^{\star \star} & (0.040)^{\star} & (0.041)^{\star \star} & (0.041)^{\star} & (0.041)^{\star \star} \\ -0.097 & -0.101 & -0.094 & -0.095 & -0.098 & -0.092 & -0.079 & -0.095 & -0.073 & -0.081 \\ (0.041)^{\star \star} & (0.042)^{\star \star} & (0.041)^{\star \star} & (0.042)^{\star \star} & (0.042)^{\star \star} & (0.042)^{\star \star} & (0.041)^{\star} & (0.041)^{\star \star} & (0.042)^{\star} & (0.042)^{\star} \\ -0.019 & -0.020 & -0.017 & -0.018 & -0.018 & -0.020 & -0.016 & -0.018 & -0.016 & -0.022 \\ (0.021) & (0.021) & (0.021) & (0.021) & (0.021) & (0.021) & (0.021) & (0.021) & (0.021) & (0.021) \\ 0.042 & 0.040 & 0.045 & 0.044 & 0.044 & 0.041 & 0.047 & 0.044 & 0.049 & 0.038 \\ (0.024)^{\star} & (0.024)^{\star} & (0.024)^{\star} & (0.024)^{\star} & (0.024)^{\star} & (0.024)^{\star} & (0.024)^{\star} & (0.024)^{\star} & (0.024)^{\star \star} & (0.024) \\ -0.024 & -0.026 & -0.026 & -0.025 & -0.025 & -0.022 & -0.011 & -0.025 & -0.012 & -0.014 \\ (0.020) & (0.020) & (0.020) & (0.020) & (0.020) & (0.020) & (0.020) & (0.020) & (0.020) & (0.020) \\ 0.170 & 0.171 & 0.170 & 0.171 & 0.171 & 0.166 & 0.158 & 0.170 & 0.156 & 0.155\end{array}$

At least some college

College_graduate

Middle wealth

High wealth

Excellent or very good health

Fair or poor health

Missing indicator: Cognitive abilities

Missing indicator: Future time perspective $(0.035)^{\star \star \star}$

$(0.035)^{\star \star \star} \quad(0.035)^{\star \star \star}$

$(0.035)^{\star \star \star}$

$\begin{array}{llll}0.087 & -0.274 & -0.157 & -0.177 \\ (0.215) & (0.243) & (0.230) & (0.291)\end{array}$

$(0.035)^{\star \star \star}$

$(0.035)^{\star *}$

$(0.035)^{\star}$

$(0.035)^{\star \star \star}$

$(0.035)^{\star \star \star}$

Missing indicator: Social

Security expectations

\begin{tabular}{|c|c|c|c|c|c|c|c|c|c|c|}
\hline \multirow{3}{*}{ Missing indicator: Wealth } & & & & & & & & $(0.037)^{\star \star \star}$ & $(0.036)^{\star \star \star}$ & $(0.038)^{\star \star \star}$ \\
\hline & -0.018 & -0.022 & -0.019 & -0.020 & -0.019 & -0.011 & -0.006 & -0.016 & 0.002 & -0.004 \\
\hline & $(0.088)$ & $(0.089)$ & $(0.087)$ & $(0.088)$ & $(0.087)$ & $(0.089)$ & $(0.088)$ & $(0.088)$ & $(0.088)$ & $(0.086)$ \\
\hline \multirow[t]{2}{*}{ Constant } & 0.238 & 0.129 & 0.480 & 0.365 & 0.388 & 0.337 & 0.307 & 0.262 & 0.524 & 0.421 \\
\hline & $(0.043)^{\star \star \star}$ & $(0.211)$ & $(0.242)^{\star \star}$ & $(0.228)$ & $(0.287)$ & $(0.075)^{\star \star \star}$ & $(0.047)^{\star \star \star}$ & $(0.047)^{\star \star \star}$ & $(0.296)^{\star}$ & $(0.283)$ \\
\hline
\end{tabular}




\begin{tabular}{|c|c|c|c|c|c|c|c|c|c|c|}
\hline & (1) & (2) & (3) & (4) & (5) & (6) & (7) & (8) & (9) & (10) \\
\hline VARIABLES & \multicolumn{10}{|c|}{ Plans to Retire Early $(\mathrm{P} 62<20)$} \\
\hline Observations & 1,864 & 1,864 & 1,864 & 1,864 & 1,864 & 1,864 & 1,864 & 1,864 & 1,864 & 1,864 \\
\hline
\end{tabular}


Table B4c. Planning to Retire Early (P62 < 20\%)

\begin{tabular}{|c|c|c|c|c|c|c|}
\hline \multirow[b]{2}{*}{ VARIABLES } & (1) & (2) & (3) & (4) & (5) & (6) \\
\hline & \multicolumn{6}{|c|}{ Plans to Retire Early (P62 < 20) } \\
\hline \multirow[t]{2}{*}{ Financial literacy index } & -0.008 & -0.002 & -0.003 & & & \\
\hline & $(0.007)$ & $(0.008)$ & $(0.008)$ & & & \\
\hline \multirow{3}{*}{$\begin{array}{l}\text { Maximizing: having high } \\
\text { standards }\end{array}$} & & & & & & \\
\hline & & & & 0.027 & 0.030 & 0.030 \\
\hline & & & & $(0.011)^{\star \star}$ & $(0.011)^{\star \star \star}$ & $(0.011)^{\star \star \star}$ \\
\hline \multirow[t]{2}{*}{ Maximizing: continual search } & & & & -0.033 & -0.029 & -0.026 \\
\hline & & & & $(0.012)^{\star \star \star}$ & $(0.012)^{\star \star}$ & $(0.012)^{\star \star}$ \\
\hline \multirow[t]{2}{*}{ Maximizing: decision difficulty } & & & & 0.021 & 0.017 & 0.016 \\
\hline & & & & $(0.010)^{\star \star}$ & $(0.010)^{*}$ & $(0.010)$ \\
\hline \multirow[t]{2}{*}{ Age 45 to 49} & & & & & & -0.169 \\
\hline & & & & & & $(0.043)^{\star \star \star}$ \\
\hline \multirow[t]{2}{*}{ Age 50 to 54} & & & 0.005 & & & -0.152 \\
\hline & & & $(0.027)$ & & & $(0.042)^{\star \star \star}$ \\
\hline \multirow[t]{2}{*}{ Age 55 to 59} & & & 0.041 & & & -0.113 \\
\hline & & & $(0.028)$ & & & $(0.043)^{\star \star \star}$ \\
\hline \multirow[t]{2}{*}{ Age 60 to 64} & & & 0.143 & & & \\
\hline & & & $(0.041)^{\star \star \star}$ & & & \\
\hline \multirow[t]{2}{*}{ Male } & & -0.051 & -0.055 & & -0.044 & -0.047 \\
\hline & & $(0.024)^{\star \star}$ & $(0.024)^{\star \star}$ & & $(0.024)^{*}$ & $(0.024)^{\star \star}$ \\
\hline \multirow[t]{2}{*}{ Married } & & 0.080 & 0.074 & & 0.078 & 0.070 \\
\hline & & $(0.030)^{\star \star \star}$ & $(0.030)^{\star \star}$ & & $(0.031)^{\star \star}$ & $(0.031)^{\star \star}$ \\
\hline \multirow[t]{2}{*}{ Divorced } & & 0.022 & 0.016 & & 0.012 & 0.003 \\
\hline & & $(0.035)$ & $(0.035)$ & & $(0.037)$ & $(0.037)$ \\
\hline \multirow[t]{2}{*}{ High school graduate } & & -0.140 & -0.144 & & -0.084 & -0.089 \\
\hline & & $(0.068)^{\star \star}$ & $(0.068)^{\star \star}$ & & $(0.071)$ & $(0.070)$ \\
\hline \multirow[t]{2}{*}{ At least some college } & & -0.127 & -0.133 & & -0.083 & -0.093 \\
\hline & & $(0.067)^{\star}$ & $(0.067)^{\star \star}$ & & $(0.069)$ & $(0.068)$ \\
\hline \multirow[t]{2}{*}{ College_graduate } & & -0.143 & -0.147 & & -0.090 & -0.100 \\
\hline & & $(0.069)^{\star \star}$ & $(0.068)^{\star \star}$ & & $(0.069)$ & $(0.068)$ \\
\hline \multirow[t]{2}{*}{ Middle wealth } & & -0.008 & -0.017 & & -0.008 & -0.016 \\
\hline & & $(0.027)$ & $(0.027)$ & & $(0.030)$ & $(0.029)$ \\
\hline \multirow[t]{2}{*}{ High wealth } & & 0.062 & 0.044 & & 0.044 & 0.026 \\
\hline & & $(0.031)^{\star \star}$ & $(0.031)$ & & $(0.031)$ & $(0.031)$ \\
\hline \multirow[t]{2}{*}{ Excellent or very good health } & & -0.030 & -0.028 & & -0.044 & -0.041 \\
\hline & & $(0.025)$ & $(0.025)$ & & $(0.026)^{\star}$ & $(0.026)$ \\
\hline \multirow[t]{2}{*}{ Fair or poor health } & & 0.207 & 0.204 & & 0.218 & 0.220 \\
\hline & & $(0.050)^{\star \star \star}$ & $(0.050)^{\star \star \star}$ & & $(0.054)^{\star \star \star}$ & $(0.054)^{\star \star \star}$ \\
\hline \multirow[t]{2}{*}{ Missing indicator: Wealth } & & 0.078 & 0.071 & & 0.085 & 0.082 \\
\hline & & $(0.124)$ & $(0.121)$ & & $(0.117)$ & $(0.113)$ \\
\hline \multirow[t]{2}{*}{ Constant } & 0.191 & 0.262 & 0.249 & 0.089 & 0.113 & 0.260 \\
\hline & $(0.012)^{\star \star \star}$ & $(0.071)^{\star \star \star}$ & $(0.073)^{\star \star \star}$ & $(0.065)$ & $(0.093)$ & $(0.100)^{\star \star \star}$ \\
\hline
\end{tabular}


(1)

VARIABLES

Observations

* Two-sided p-value < 10; **

NOTE: Numbers reported are regression coefficients, with standard errors in parentheses.
(5)

(6)

\section{Plans to Retire Early (P62 < 20)}

$196 \quad 1,196 \quad 1,098 \quad 1,098$
1,098 


\section{Retirement Age}

Table B5a. Retirement Age

$\begin{array}{lllllll}(1) & \text { (2) } & \text { (3) } & \text { (4) } & \text { (5) } & \text { (6) }\end{array}$

VARIABLES

Retirement age (ms67 supplemented by hhbox 2 quarters )

\begin{tabular}{|c|c|c|c|c|c|c|c|}
\hline \multirow{2}{*}{$\begin{array}{l}\text { Cognitive ability: Number } \\
\text { series }\end{array}$} & 0.011 & & & 0.011 & & & 0.013 \\
\hline & $(0.009)$ & & & $(0.009)$ & & & $(0.009)$ \\
\hline \multirow{2}{*}{$\begin{array}{l}\text { Cognitive ability: Picture } \\
\text { vocabulary }\end{array}$} & & 0.007 & & 0.005 & & & 0.003 \\
\hline & & $(0.010)$ & & $(0.010)$ & & & $(0.010)$ \\
\hline \multirow{2}{*}{$\begin{array}{l}\text { Cognitive ability: Verbal } \\
\text { analogies }\end{array}$} & & & 0.004 & -0.003 & & & -0.002 \\
\hline & & & $(0.010)$ & $(0.010)$ & & & $(0.010)$ \\
\hline \multirow[t]{2}{*}{ Focus on opportunities } & & & & & -0.778 & & -0.783 \\
\hline & & & & & $(0.176)^{\star \star \star}$ & & $(0.174)^{\star \star \star}$ \\
\hline \multirow[t]{2}{*}{ Focus on limitations } & & & & & 0.162 & & 0.161 \\
\hline & & & & & $(0.195)$ & & $(0.196)$ \\
\hline \multirow[t]{2}{*}{ Social Security expectations } & & & & & & -0.005 & -0.008 \\
\hline & & & & & & $(0.007)$ & $(0.007)$ \\
\hline \multirow{2}{*}{$\begin{array}{l}\text { Missing indicator: Cognitive } \\
\text { abilities }\end{array}$} & 5.629 & 3.973 & 1.940 & 6.954 & & & 7.538 \\
\hline & $(4.696)$ & $(5.372)$ & $(5.110)$ & (7.073) & & & $(7.125)$ \\
\hline \multirow{2}{*}{$\begin{array}{l}\text { Missing indicator: Future time } \\
\text { perspective }\end{array}$} & & & & & -2.569 & & -2.541 \\
\hline & & & & & $(1.376)^{\star}$ & & $(1.356)^{\star}$ \\
\hline \multirow{2}{*}{$\begin{array}{l}\text { Missing indicator: Social } \\
\text { Security expectations }\end{array}$} & & & & & & 6.930 & 6.485 \\
\hline & & & & & & $(5.140)$ & $(5.454)$ \\
\hline \multirow[t]{2}{*}{ Constant } & 53.580 & 55.236 & 57.269 & 52.255 & 61.582 & 59.653 & 54.328 \\
\hline & $(4.665)^{\star \star \star}$ & $(5.344)^{\star \star \star}$ & $(5.080)^{\star \star \star}$ & $(7.052)^{\star \star \star}$ & $(1.291)^{\star \star \star}$ & $(0.449)^{\star \star \star}$ & $(7.099)^{\star \star \star}$ \\
\hline Observations & 1,079 & 1,079 & 1,079 & 1,079 & 1,079 & 1,079 & 1,079 \\
\hline
\end{tabular}

* Two-sided $p$-value $<.10 ; * *<<.05 ; * \star * ~ p<.01$

NOTE: Numbers reported are regression coefficients, with standard errors in parentheses. 
Table B5b. Retirement Age

\begin{tabular}{|c|c|c|c|c|c|c|c|c|c|}
\hline \multirow[b]{2}{*}{ VARIABLES } & (1) & (2) & (3) & (4) & (5) & (6) & (7) & (8) & (9) \\
\hline & \multicolumn{9}{|c|}{ Retirement age (ms67 supplemented by hhbox 2 quarters ) } \\
\hline \multirow[t]{2}{*}{ Cognitive ability: Number series } & & 0.006 & & & 0.009 & & & 0.011 & 0.013 \\
\hline & & $(0.009)$ & & & $(0.010)$ & & & $(0.010)$ & $(0.009)$ \\
\hline \multirow[t]{2}{*}{ Cognitive ability: Picture vocabulary } & & & 0.002 & & 0.002 & & & 0.000 & -0.011 \\
\hline & & & $(0.009)$ & & $(0.010)$ & & & $(0.009)$ & $(0.008)$ \\
\hline \multirow[t]{2}{*}{ Cognitive ability: Verbal analogies } & & & & -0.003 & -0.008 & & & -0.009 & -0.003 \\
\hline & & & & $(0.010)$ & $(0.010)$ & & & $(0.010)$ & $(0.009)$ \\
\hline \multirow[t]{2}{*}{ Focus on opportunities } & & & & & & -0.881 & & -0.869 & -0.248 \\
\hline & & & & & & $(0.179)^{\star \star \star}$ & & $(0.178)^{\star \star \star}$ & $(0.146)^{\star}$ \\
\hline \multirow[t]{2}{*}{ Focus on limitations } & & & & & & 0.242 & & 0.269 & -0.085 \\
\hline & & & & & & $(0.195)$ & & $(0.196)$ & $(0.159)$ \\
\hline \multirow[t]{2}{*}{ Social Security expectations } & & & & & & & -0.005 & -0.006 & 0.003 \\
\hline & & & & & & & $(0.007)$ & $(0.007)$ & $(0.005)$ \\
\hline \multirow[t]{2}{*}{ Age 45 to 49} & & & & & & & & & -15.383 \\
\hline & & & & & & & & & $(0.683)^{\star \star \star}$ \\
\hline \multirow{2}{*}{ Age 50 to 54} & & & & & & & & & -11.238 \\
\hline & & & & & & & & & $(0.564)^{\star \star \star}$ \\
\hline \multirow[t]{2}{*}{ Age 55 to 59} & & & & & & & & & -8.186 \\
\hline & & & & & & & & & $(0.493)^{\star \star \star}$ \\
\hline \multirow[t]{2}{*}{ Age 60 to 64} & & & & & & & & & -3.446 \\
\hline & & & & & & & & & $(0.462)^{\star \star \star}$ \\
\hline \multirow[t]{2}{*}{ Age 65 to 69} & & & & & & & & & -1.281 \\
\hline & & & & & & & & & $(0.467)^{\star \star \star}$ \\
\hline \multirow[t]{2}{*}{ Male } & 0.124 & 0.092 & 0.120 & 0.105 & 0.053 & -0.051 & 0.123 & -0.142 & -0.576 \\
\hline & $(0.393)$ & $(0.393)$ & (0.393) & $(0.395)$ & $(0.398)$ & (0.391) & $(0.391)$ & (0.394) & $(0.334)^{\star}$ \\
\hline \multirow[t]{2}{*}{ Married } & -0.442 & -0.464 & -0.441 & -0.430 & -0.470 & -0.640 & -0.404 & -0.637 & 0.108 \\
\hline & $(0.482)$ & $(0.486)$ & $(0.482)$ & $(0.483)$ & $(0.486)$ & $(0.475)$ & $(0.482)$ & $(0.479)$ & $(0.404)$ \\
\hline
\end{tabular}




\begin{tabular}{|c|c|c|c|c|c|c|c|c|c|}
\hline \multirow[b]{2}{*}{ VARIABLES } & (1) & (2) & (3) & (4) & (5) & (6) & (7) & (8) & (9) \\
\hline & \multicolumn{9}{|c|}{ Retirement age (ms67 supplemented by hhbox 2 quarters ) } \\
\hline \multirow[t]{2}{*}{ Divorced } & 1.260 & 1.271 & 1.258 & 1.259 & 1.271 & 1.131 & 1.249 & 1.140 & 1.246 \\
\hline & $(0.625)^{\star \star}$ & $(0.624)^{\star \star}$ & $(0.625)^{\star \star}$ & $(0.626)^{\star \star}$ & $(0.625)^{\star *}$ & $(0.619)^{*}$ & $(0.622)^{\star *}$ & $(0.616)^{\star}$ & $(0.499)^{\star *}$ \\
\hline \multirow[t]{2}{*}{ High school graduate } & 0.944 & 0.930 & 0.941 & 0.988 & 0.975 & 0.685 & 0.959 & 0.726 & -0.319 \\
\hline & $(0.887)$ & $(0.889)$ & $(0.886)$ & $(0.883)$ & $(0.880)$ & $(0.878)$ & $(0.871)$ & $(0.854)$ & $(0.699)$ \\
\hline \multirow[t]{2}{*}{ At least some college } & 0.026 & -0.010 & 0.019 & 0.075 & 0.023 & -0.151 & 0.064 & -0.120 & -0.423 \\
\hline & $(0.862)$ & $(0.864)$ & $(0.862)$ & $(0.854)$ & $(0.855)$ & $(0.852)$ & $(0.848)$ & $(0.831)$ & $(0.669)$ \\
\hline \multirow[t]{2}{*}{ College_graduate } & 0.406 & 0.338 & 0.400 & 0.478 & 0.406 & 0.471 & 0.461 & 0.510 & 0.267 \\
\hline & $(0.866)$ & $(0.879)$ & $(0.869)$ & $(0.860)$ & $(0.867)$ & $(0.856)$ & $(0.851)$ & $(0.841)$ & $(0.666)$ \\
\hline \multirow[t]{2}{*}{ Middle wealth } & 0.900 & 0.869 & 0.891 & 0.914 & 0.882 & 0.696 & 0.989 & 0.763 & -0.019 \\
\hline & $(0.496)^{\star}$ & $(0.497)^{\star}$ & $(0.497)^{\star}$ & $(0.494)^{\star}$ & $(0.497)^{\star}$ & $(0.495)$ & $(0.496)^{\star \star}$ & $(0.497)$ & $(0.415)$ \\
\hline \multirow[t]{2}{*}{ High wealth } & 1.089 & 1.048 & 1.077 & 1.107 & 1.056 & 0.701 & 1.185 & 0.765 & 0.193 \\
\hline & $(0.523)^{\star \star}$ & $(0.525)^{\star \star}$ & $(0.523)^{\star \star}$ & $(0.522)^{\star \star}$ & $(0.524)^{\star \star}$ & $(0.523)$ & $(0.526)^{\star \star}$ & $(0.527)$ & $(0.434)$ \\
\hline \multirow[t]{2}{*}{ Excellent or very good health } & -0.269 & -0.280 & -0.270 & -0.263 & -0.277 & 0.145 & -0.233 & 0.171 & -0.018 \\
\hline & $(0.425)$ & $(0.424)$ & $(0.426)$ & $(0.426)$ & $(0.425)$ & $(0.422)$ & $(0.424)$ & $(0.422)$ & $(0.351)$ \\
\hline \multirow[t]{2}{*}{ Fair or poor health } & -3.095 & -3.105 & -3.107 & -3.102 & -3.101 & -3.317 & -3.046 & -3.268 & -1.942 \\
\hline & $(0.639)^{\star \star \star}$ & $(0.645)^{\star \star \star}$ & $(0.645)^{\star \star \star}$ & $(0.645)^{\star \star \star}$ & $(0.647)^{\star \star \star}$ & $(0.624)^{\star \star \star}$ & $(0.634)^{\star \star \star}$ & $(0.626)^{\star \star *}$ & $(0.522)^{\star \star \star}$ \\
\hline \multirow[t]{2}{*}{ Missing indicator: Cognitive abilities } & & 3.513 & 1.420 & -1.648 & 2.024 & & & 1.712 & -0.848 \\
\hline & & $(5.042)$ & $(5.232)$ & $(5.080)$ & $(7.156)$ & & & $(7.267)$ & $(6.048)$ \\
\hline \multirow[t]{2}{*}{ Missing indicator: Future time perspective } & & & & & & -2.318 & & -2.193 & -1.353 \\
\hline & & & & & & $(1.376)^{\star}$ & & $(1.357)$ & $(1.064)$ \\
\hline \multirow[t]{2}{*}{ Missing indicator: Social Security expectations } & & & & & & & 7.900 & 7.257 & 4.799 \\
\hline & & & & & & & $(5.073)$ & $(5.568)$ & $(4.998)$ \\
\hline \multirow[t]{2}{*}{ Missing indicator: Wealth } & 1.604 & 1.582 & 1.600 & 1.625 & 1.567 & 1.469 & 1.652 & 1.467 & 0.454 \\
\hline & $(1.326)$ & $(1.325)$ & $(1.325)$ & $(1.321)$ & $(1.315)$ & $(1.278)$ & $(1.335)$ & $(1.271)$ & $(1.139)$ \\
\hline \multirow[t]{2}{*}{ Constant } & 58.916 & 55.623 & 57.641 & 60.638 & 57.084 & 61.463 & 59.034 & 59.960 & 64.988 \\
\hline & $(0.964)^{\star \star \star}$ & $(5.007)^{\star \star \star}$ & $(5.263)^{\star \star \star}$ & $(5.189)^{\star \star \star}$ & $(7.152)^{\star \star \star}$ & $(1.663)^{\star \star \star}$ & $(1.015)^{\star \star \star}$ & $(7.282)^{\star \star \star}$ & $(6.061)^{\star \star \star}$ \\
\hline Observations & 1,079 & 1,079 & 1,079 & 1,079 & 1,079 & 1,079 & 1,079 & 1,079 & 1,079 \\
\hline
\end{tabular}

* Two-sided $\mathrm{p}$-value $<.10 ;{ }^{* \star} \mathrm{p}<.05 ;$ *** $\mathrm{p}<.01$

NOTE: Numbers reported are regression coefficients, with standard errors in parentheses. 
Table B5c. Retirement Age

\begin{tabular}{|c|c|c|c|c|c|c|}
\hline \multirow[b]{2}{*}{ VARIABLES } & (1) & (2) & (3) & (4) & (5) & (6) \\
\hline & \multicolumn{6}{|c|}{ Retirement age (ms67 supplemented by hhbox 2 quarters ) } \\
\hline \multirow[t]{2}{*}{ Financial literacy index } & 0.180 & 0.162 & -0.074 & & & \\
\hline & $(0.148)$ & $(0.169)$ & $(0.141)$ & & & \\
\hline \multirow{3}{*}{$\begin{array}{l}\text { Maximizing: having high } \\
\text { standards }\end{array}$} & & & & & & \\
\hline & & & & -0.254 & -0.401 & -0.333 \\
\hline & & & & $(0.213)$ & $(0.216)^{\star}$ & $(0.178)^{\star}$ \\
\hline \multirow[t]{2}{*}{ Maximizing: continual search } & & & & -0.632 & -0.621 & -0.021 \\
\hline & & & & $(0.237)^{\star \star \star}$ & $(0.240)^{\star \star \star}$ & $(0.188)$ \\
\hline \multirow[t]{2}{*}{ Maximizing: decision difficulty } & & & & 0.363 & 0.371 & 0.164 \\
\hline & & & & $(0.193)^{\star}$ & $(0.192)^{\star}$ & $(0.161)$ \\
\hline \multirow[t]{2}{*}{ Age 45 to 49} & & & -15.187 & & & -15.340 \\
\hline & & & $(1.033)^{\star \star \star}$ & & & $(1.002)^{\star \star \star}$ \\
\hline \multirow[t]{2}{*}{ Age 50 to 54} & & & -10.830 & & & -10.745 \\
\hline & & & $(0.698)^{\star \star \star}$ & & & $(0.750)^{\star \star \star}$ \\
\hline \multirow[t]{2}{*}{ Age 55 to 59} & & & -8.186 & & & -8.098 \\
\hline & & & $(0.609)^{\star \star \star}$ & & & $(0.631)^{\star \star \star}$ \\
\hline \multirow[t]{2}{*}{ Age 60 to 64} & & & -3.296 & & & -3.059 \\
\hline & & & $(0.569)^{\star \star \star}$ & & & $(0.566)^{\star \star \star}$ \\
\hline \multirow[t]{2}{*}{ Age 65 to 69} & & & -0.939 & & & -0.730 \\
\hline & & & $(0.583)$ & & & $(0.574)$ \\
\hline \multirow[t]{2}{*}{ Male } & & 0.298 & -0.316 & & 0.547 & -0.232 \\
\hline & & $(0.485)$ & $(0.413)$ & & $(0.491)$ & $(0.415)$ \\
\hline \multirow[t]{2}{*}{ Married } & & -0.739 & -0.003 & & -0.392 & 0.342 \\
\hline & & $(0.615)$ & (0.524) & & $(0.633)$ & $(0.541)$ \\
\hline \multirow[t]{2}{*}{ Divorced } & & 0.611 & 0.544 & & 1.172 & 1.064 \\
\hline & & $(0.768)$ & $(0.640)$ & & $(0.778)$ & $(0.651)$ \\
\hline \multirow[t]{2}{*}{ High school graduate } & & -0.084 & -0.573 & & 0.753 & -0.165 \\
\hline & & $(1.138)$ & $(0.939)$ & & $(1.261)$ & $(1.042)$ \\
\hline \multirow[t]{2}{*}{ At least some college } & & -0.949 & -0.463 & & -0.499 & -0.549 \\
\hline & & $(1.126)$ & $(0.913)$ & & $(1.230)$ & (1.004) \\
\hline \multirow[t]{2}{*}{ College_graduate } & & -1.210 & -0.355 & & -0.297 & -0.162 \\
\hline & & $(1.158)$ & $(0.937)$ & & (1.249) & $(1.010)$ \\
\hline \multirow[t]{2}{*}{ Middle wealth } & & 0.848 & 0.071 & & 0.477 & -0.055 \\
\hline & & $(0.640)$ & $(0.540)$ & & $(0.654)$ & $(0.537)$ \\
\hline \multirow[t]{2}{*}{ High wealth } & & 1.038 & 0.662 & & 1.043 & 0.627 \\
\hline & & $(0.681)$ & $(0.556)$ & & $(0.702)$ & $(0.566)$ \\
\hline \multirow[t]{2}{*}{ Excellent or very good health } & & -0.281 & 0.105 & & 0.086 & 0.211 \\
\hline & & $(0.508)$ & $(0.426)$ & & $(0.502)$ & $(0.419)$ \\
\hline \multirow[t]{2}{*}{ Fair or poor health } & & -2.920 & -1.603 & & -2.554 & -1.390 \\
\hline & & $(0.819)^{\star \star \star}$ & $(0.689)^{\star \star}$ & & $(0.919)^{\star \star \star}$ & $(0.754)^{\star}$ \\
\hline
\end{tabular}


(1)

(2)

(3)

(4)

(5)

(6)

VARIABLES

Retirement age (ms67 supplemented by hhbox 2 quarters)

\begin{tabular}{lcccccc} 
Missing indicator: Wealth & & 2.190 & 0.775 & & 1.375 & 1.177 \\
& & $(1.865)$ & $(1.670)$ & & $(1.906)$ & $(1.556)$ \\
\hline Constant & 59.495 & 60.339 & 62.899 & 61.543 & 61.750 & 63.258 \\
& $(0.246)^{\star \star \star}$ & $(1.238)^{\star \star \star}$ & $(1.058)^{\star \star \star}$ & $(1.258)^{\star \star \star}$ & $(1.837)^{\star \star \star}$ & $(1.540)^{\star \star \star}$ \\
\hline Observations & 712 & 712 & 712 & 656 & 656 & 656 \\
\hline
\end{tabular}

* Two-sided $p$-value $<.10 ; * \star p<.05 ; * \star *<<.01$.

NOTE: Numbers reported are regression coefficients, with standard errors in parentheses. 
Table B6a. Retired Before Age 62

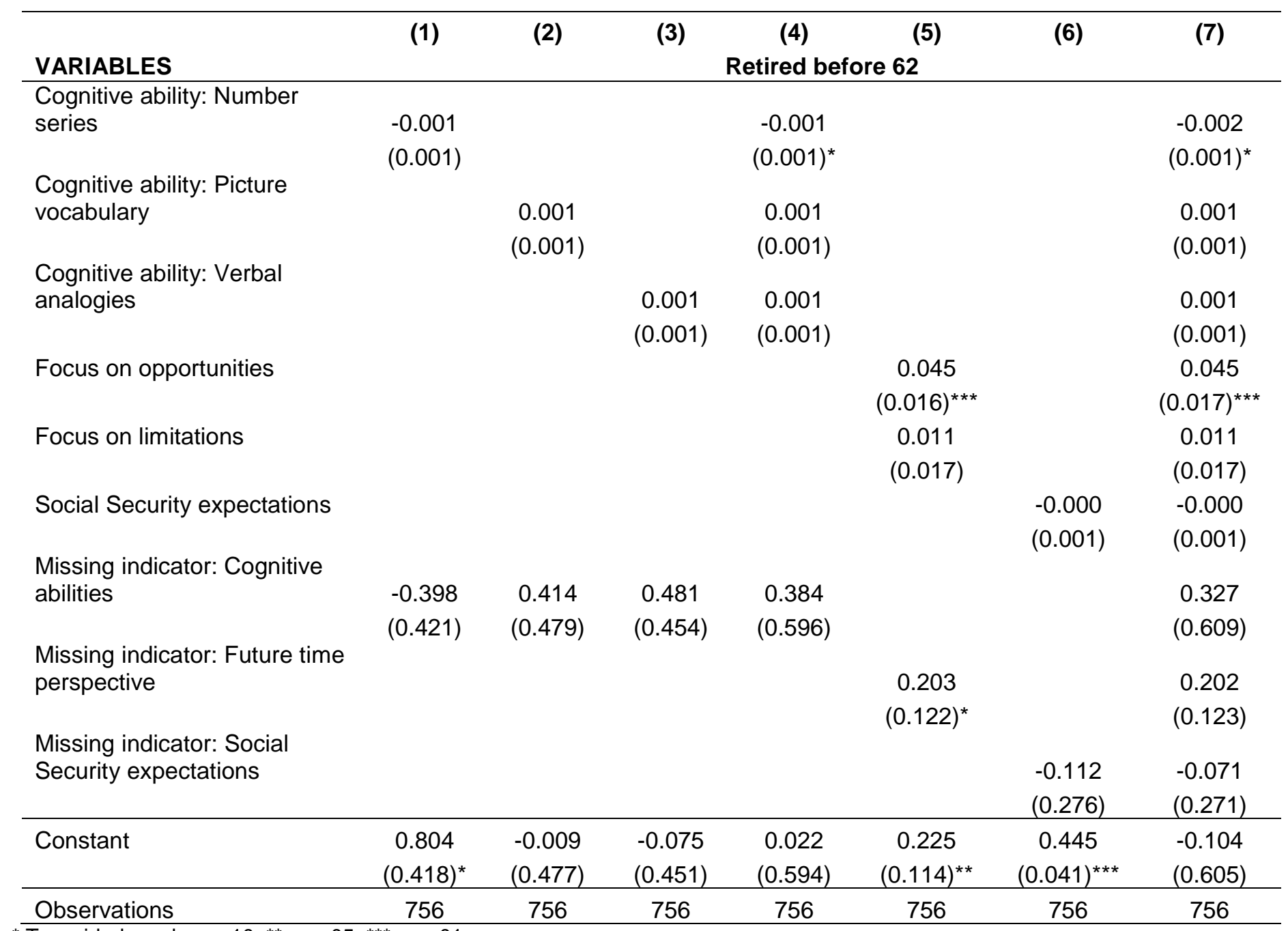

* Two-sided $\mathrm{p}$-value $<.10 ;{ }^{* \star} \mathrm{p}<.05 ;$ *** $\mathrm{p}<.01$.

NOTE: Numbers reported are regression coefficients, with standard errors in parentheses. 
Table B6b. Retired Before Age 62

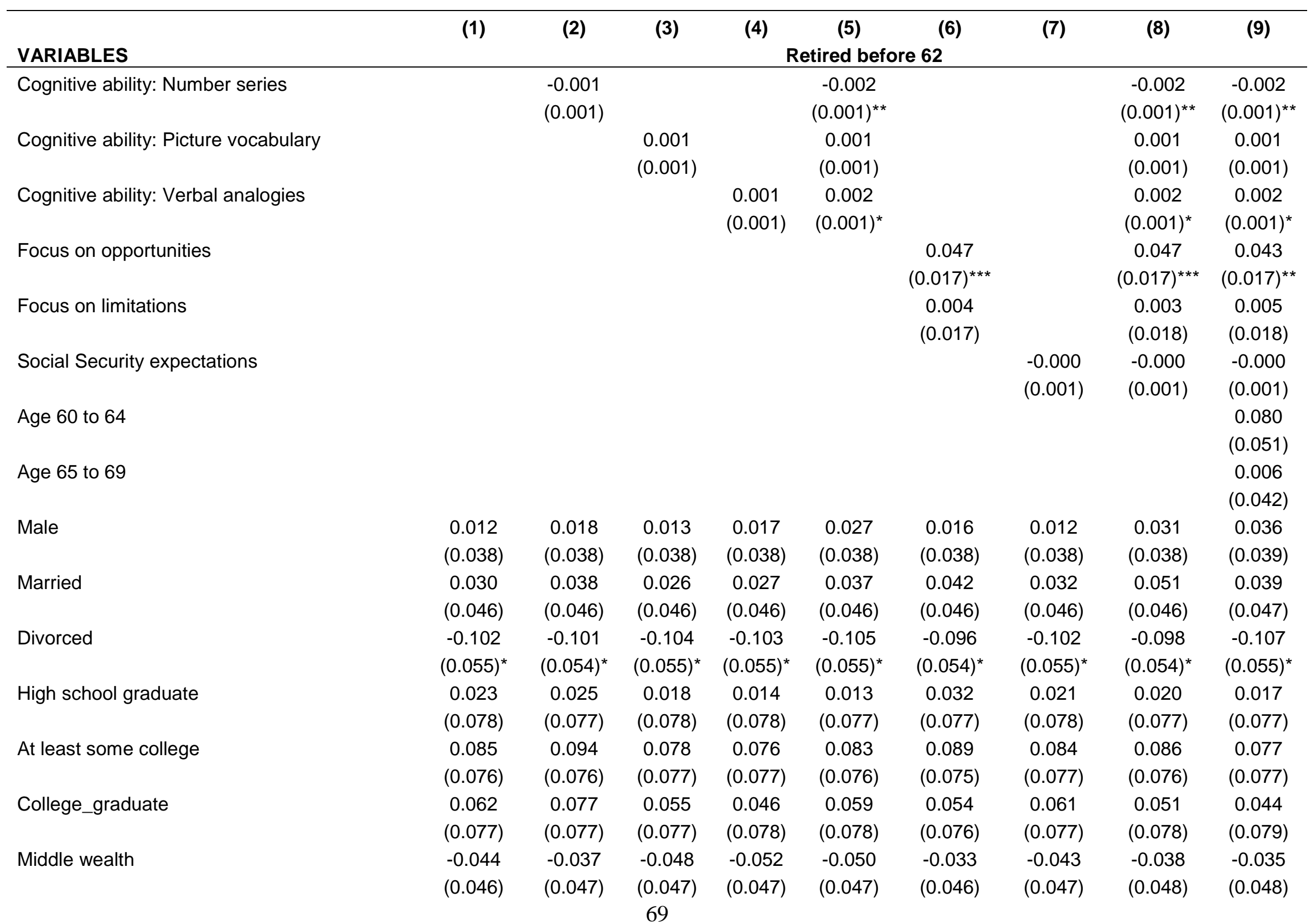


(1)

(2)

(3)

(4)

(5)

(6)

(7)

(8)

(9)

VARIABLES

$\begin{array}{llllll}-0.017 & -0.010 & -0.022 & -0.023 & -0.018 & 0.003\end{array}$

$\begin{array}{llllll}(0.050) & (0.050) & (0.050) & (0.050) & (0.051) & (0.050)\end{array}$

$-0.014$

0.005

0.009

$\begin{array}{llll}0.032 & 0.034 & 0.031 & 0.031\end{array}$

Excellent or very good health

$(0.040)$

$\begin{array}{ccc}0.034 & 0.031 & 0.031 \\ (0.040) & (0.040) & (0.040)\end{array}$

0.034

0.017

0.031

0.018

0.013

Fair or poor health

$(0.060)^{*}$

$\begin{array}{lllll}0.104 & 0.104 & 0.104 & 0.104 & 0.115\end{array}$

$(0.040)$

$(0.040)$

0.110

Missing indicator: Cognitive abilities

$\begin{array}{cccc}(0.060)^{\star} & (0.060)^{\star} & (0.060)^{\star} & (0.060)^{\star}\end{array}$

$(0.060)^{*}$

$(0.060)^{*}$

0.119

$\begin{array}{llll}-0.650 & 0.408 & 0.550 & 0.257\end{array}$

$\begin{array}{llll}(0.451) & (0.497) \quad(0.478) & (0.647)\end{array}$

Missing indicator: Future time perspective

0.176

0.176
$(0.122)$

$(0.061)$

$0.230 \quad 0.214$

(0.665) (0.661)

$0.167 \quad 0.164$

(0.123) (0.122)

Missing indicator: Social Security expectations

\begin{tabular}{lccccccccc} 
& & & & \multicolumn{1}{c}{$(0.274)$} & $(0.284)$ & $(0.282)$ \\
Missing indicator: Wealth & 0.063 & 0.068 & 0.055 & 0.060 & 0.065 & 0.067 & 0.060 & 0.067 & 0.064 \\
& $(0.121)$ & $(0.121)$ & $(0.120)$ & $(0.120)$ & $(0.119)$ & $(0.122)$ & $(0.120)$ & $(0.119)$ & $(0.121)$ \\
\hline Constant & 0.357 & 0.966 & -0.059 & -0.198 & 0.075 & 0.164 & 0.382 & -0.060 & -0.039 \\
& $(0.080)^{\star \star *}$ & $(0.442)^{\star *}$ & $(0.490)$ & $(0.469)$ & $(0.632)$ & $(0.133)$ & $(0.087)^{\star \star *}$ & $(0.646)$ & $(0.642)$ \\
\hline Observations & 756 & 756 & 756 & 756 & 756 & 756 & 756 & 756 & 756 \\
\hline
\end{tabular}

* Two-sided $p$-value $<.10 ;{ }^{* \star} p<.05 ;$ *** $p<.01$.

NOTE: Numbers reported are regression coefficients, with standard errors in parentheses. 
Table B6c. Retired Before Age 62

\begin{tabular}{|c|c|c|c|c|c|c|}
\hline \multirow[b]{2}{*}{ VARIABLES } & (1) & (2) & (3) & (4) & (5) & (6) \\
\hline & \multicolumn{6}{|c|}{ Retired before 62} \\
\hline \multirow[t]{2}{*}{ Financial literacy index } & 0.011 & 0.002 & 0.003 & & & \\
\hline & $(0.014)$ & $(0.017)$ & $(0.017)$ & & & \\
\hline \multirow[t]{2}{*}{$\begin{array}{l}\text { Maximizing: having high } \\
\text { standards }\end{array}$} & & & & -0.005 & -0.001 & -0.002 \\
\hline & & & & $(0.021)$ & $(0.022)$ & $(0.021)$ \\
\hline \multirow[t]{2}{*}{ Maximizing: continual search } & & & & 0.025 & 0.025 & 0.016 \\
\hline & & & & $(0.023)$ & $(0.024)$ & $(0.024)$ \\
\hline \multirow[t]{2}{*}{ Maximizing: decision difficulty } & & & & -0.033 & -0.031 & -0.027 \\
\hline & & & & $(0.020)^{\star}$ & $(0.021)$ & $(0.020)$ \\
\hline \multirow[t]{2}{*}{ Age 60 to 64} & & & 0.097 & & & 0.147 \\
\hline & & & $(0.059)$ & & & $(0.063)^{\star \star}$ \\
\hline \multirow[t]{2}{*}{ Age 65 to 69} & & & 0.022 & & & 0.029 \\
\hline & & & $(0.053)$ & & & $(0.056)$ \\
\hline \multirow[t]{2}{*}{ Male } & & -0.000 & 0.006 & & -0.001 & 0.013 \\
\hline & & $(0.048)$ & $(0.048)$ & & $(0.051)$ & $(0.051)$ \\
\hline \multirow[t]{2}{*}{ Married } & & 0.030 & 0.014 & & 0.004 & -0.022 \\
\hline & & $(0.058)$ & $(0.058)$ & & $(0.063)$ & $(0.063)$ \\
\hline \multirow[t]{2}{*}{ Divorced } & & -0.087 & -0.101 & & -0.119 & -0.140 \\
\hline & & $(0.069)$ & $(0.071)$ & & $(0.075)$ & $(0.076)^{\star}$ \\
\hline \multirow[t]{2}{*}{ High school graduate } & & 0.061 & 0.055 & & -0.014 & -0.022 \\
\hline & & $(0.106)$ & $(0.106)$ & & $(0.126)$ & $(0.128)$ \\
\hline \multirow[t]{2}{*}{ At least some college } & & 0.105 & 0.092 & & 0.050 & 0.033 \\
\hline & & $(0.106)$ & $(0.107)$ & & $(0.126)$ & $(0.128)$ \\
\hline \multirow[t]{2}{*}{ College_graduate } & & 0.133 & 0.119 & & 0.073 & 0.061 \\
\hline & & $(0.109)$ & $(0.110)$ & & $(0.127)$ & $(0.129)$ \\
\hline \multirow[t]{2}{*}{ Middle wealth } & & -0.024 & -0.019 & & -0.030 & -0.025 \\
\hline & & $(0.061)$ & $(0.061)$ & & $(0.065)$ & $(0.065)$ \\
\hline \multirow[t]{2}{*}{ High wealth } & & -0.015 & -0.011 & & -0.044 & -0.040 \\
\hline & & $(0.066)$ & $(0.065)$ & & $(0.068)$ & $(0.068)$ \\
\hline \multirow[t]{2}{*}{ Excellent or very good health } & & -0.003 & -0.010 & & -0.014 & -0.026 \\
\hline & & $(0.049)$ & $(0.049)$ & & $(0.051)$ & $(0.051)$ \\
\hline \multirow[t]{2}{*}{ Fair or poor health } & & 0.093 & 0.083 & & 0.060 & 0.038 \\
\hline & & $(0.078)$ & $(0.079)$ & & (0.092) & $(0.092)$ \\
\hline \multirow[t]{2}{*}{ Missing indicator: Wealth } & & 0.052 & 0.052 & & -0.129 & -0.143 \\
\hline & & $(0.158)$ & (0.159) & & $(0.147)$ & $(0.150)$ \\
\hline \multirow[t]{2}{*}{ Constant } & 0.421 & 0.329 & 0.319 & 0.503 & 0.487 & 0.491 \\
\hline & $(0.024)^{\star \star \star}$ & $(0.114)^{\star \star \star}$ & $(0.115)^{\star \star \star}$ & $(0.121)^{\star \star \star}$ & $(0.180)^{\star \star \star}$ & $(0.179)^{\star \star \star}$ \\
\hline Observations & 505 & 505 & 505 & 466 & 466 & 466 \\
\hline
\end{tabular}


Table B7a. Retired After the Full Retirement Age

\begin{tabular}{|c|c|c|c|c|c|c|c|}
\hline \multirow[b]{2}{*}{ VARIABLES } & (1) & (2) & (3) & (4) & (5) & (6) & (7) \\
\hline & \multicolumn{7}{|c|}{ Retired after Full Retirement Age } \\
\hline \multirow{2}{*}{ Cognitive ability: Number series } & -0.000 & & & 0.000 & & & 0.001 \\
\hline & $(0.001)$ & & & $(0.001)$ & & & $(0.001)$ \\
\hline \multicolumn{8}{|l|}{ Cognitive ability: Picture } \\
\hline vocabulary & & $(0.001)^{\star \star}$ & & $(0.001)^{\star \star}$ & & & $(0.001)^{\star \star}$ \\
\hline \multirow[t]{2}{*}{$\begin{array}{l}\text { Cognitive ability: Verbal } \\
\text { analogies }\end{array}$} & & & -0.001 & -0.001 & & & -0.001 \\
\hline & & & $(0.001)$ & $(0.001)$ & & & $(0.001)$ \\
\hline \multirow[t]{2}{*}{ Focus on opportunities } & & & & & -0.043 & & -0.041 \\
\hline & & & & & $(0.019)^{\star \star}$ & & $(0.019)^{\star *}$ \\
\hline \multirow[t]{2}{*}{ Focus on limitations } & & & & & -0.016 & & -0.013 \\
\hline & & & & & $(0.020)$ & & $(0.020)$ \\
\hline \multirow[t]{2}{*}{ Social Security expectations } & & & & & & -0.001 & -0.001 \\
\hline & & & & & & $(0.001)$ & $(0.001)$ \\
\hline \multirow[t]{2}{*}{$\begin{array}{l}\text { Missing indicator: Cognitive } \\
\text { abilities }\end{array}$} & -0.162 & -1.194 & -0.664 & -1.328 & & & -1.065 \\
\hline & $(0.491)$ & $(0.552)^{\star \star}$ & $(0.548)$ & $(0.707)^{\star}$ & & & $(0.719)$ \\
\hline \multirow[t]{2}{*}{$\begin{array}{l}\text { Missing indicator: Future time } \\
\text { perspective }\end{array}$} & & & & & -0.143 & & -0.118 \\
\hline & & & & & $(0.143)$ & & $(0.141)$ \\
\hline \multicolumn{8}{|l|}{ Missing indicator: Social } \\
\hline \multirow[t]{2}{*}{ Security expectations } & & & & & & 0.331 & 0.319 \\
\hline & & & & & & $(0.277)$ & $(0.263)$ \\
\hline \multirow[t]{2}{*}{ Constant } & 0.470 & 1.502 & 0.972 & 1.635 & 0.496 & 0.335 & 1.563 \\
\hline & $(0.488)$ & $(0.550)^{\star \star \star}$ & $(0.545)^{\star}$ & $(0.705)^{\star \star}$ & $(0.135)^{\star \star \star}$ & $(0.045)^{\star \star \star}$ & $(0.712)^{\star \star}$ \\
\hline Observations & 532 & 532 & 532 & 532 & 532 & 532 & 532 \\
\hline
\end{tabular}


Table B7b. Retired After the Full Retirement Age

\begin{tabular}{|c|c|c|c|c|c|c|c|c|c|}
\hline \multirow[b]{2}{*}{ VARIABLES } & (1) & (2) & (3) & (4) & (5) & (6) & (7) & (8) & (9) \\
\hline & \multicolumn{9}{|c|}{ Retired after Full Retirement Age } \\
\hline \multirow[t]{2}{*}{ Cognitive ability: Number series } & & -0.000 & & & 0.001 & & & 0.001 & 0.001 \\
\hline & & $(0.001)$ & & & $(0.001)$ & & & $(0.001)$ & $(0.001)$ \\
\hline \multirow{2}{*}{ Cognitive ability: Picture vocabulary } & & & -0.002 & & -0.002 & & & -0.002 & -0.002 \\
\hline & & & $(0.001)^{\star \star}$ & & $(0.001)^{\star}$ & & & $(0.001)^{\star \star}$ & $(0.001)^{*}$ \\
\hline \multirow[t]{2}{*}{ Cognitive ability: Verbal analogies } & & & & -0.001 & -0.001 & & & -0.001 & -0.001 \\
\hline & & & & $(0.001)$ & $(0.001)$ & & & $(0.001)$ & $(0.001)$ \\
\hline \multirow[t]{2}{*}{ Focus on opportunities } & & & & & & -0.045 & & -0.043 & -0.035 \\
\hline & & & & & & $(0.020)^{\star \star}$ & & $(0.020)^{\star \star}$ & $(0.020)^{*}$ \\
\hline \multirow[t]{2}{*}{ Focus on limitations } & & & & & & -0.013 & & -0.010 & -0.013 \\
\hline & & & & & & $(0.020)$ & & $(0.020)$ & $(0.020)$ \\
\hline \multirow[t]{2}{*}{ Social Security expectations } & & & & & & & -0.001 & -0.001 & -0.001 \\
\hline & & & & & & & $(0.001)$ & $(0.001)$ & $(0.001)$ \\
\hline \multirow[t]{2}{*}{ Age 65 to 69} & & & & & & & & & -0.154 \\
\hline & & & & & & & & & $(0.040)^{\star \star \star}$ \\
\hline \multirow[t]{2}{*}{ Male } & -0.010 & -0.010 & -0.013 & -0.014 & -0.019 & -0.013 & -0.008 & -0.021 & -0.035 \\
\hline & $(0.041)$ & $(0.041)$ & $(0.041)$ & $(0.041)$ & $(0.041)$ & $(0.041)$ & $(0.041)$ & $(0.041)$ & $(0.041)$ \\
\hline \multirow[t]{2}{*}{ Married } & 0.005 & 0.006 & 0.012 & 0.006 & 0.009 & -0.007 & 0.009 & -0.002 & 0.016 \\
\hline & $(0.048)$ & $(0.048)$ & $(0.048)$ & $(0.048)$ & $(0.048)$ & $(0.048)$ & $(0.048)$ & $(0.048)$ & $(0.048)$ \\
\hline \multirow[t]{2}{*}{ Divorced } & 0.043 & 0.043 & 0.046 & 0.044 & 0.047 & 0.036 & 0.041 & 0.039 & 0.067 \\
\hline & $(0.063)$ & $(0.063)$ & $(0.062)$ & $(0.063)$ & $(0.063)$ & $(0.062)$ & $(0.063)$ & $(0.062)$ & $(0.061)$ \\
\hline \multirow[t]{2}{*}{ High school graduate } & 0.022 & 0.023 & 0.027 & 0.029 & 0.027 & 0.022 & 0.025 & 0.026 & 0.028 \\
\hline & (0.085) & (0.085) & $(0.085)$ & $(0.084)$ & $(0.085)$ & $(0.086)$ & $(0.085)$ & $(0.085)$ & $(0.084)$ \\
\hline \multirow[t]{2}{*}{ At least some college } & 0.023 & 0.025 & 0.042 & 0.032 & 0.039 & 0.028 & 0.028 & 0.041 & 0.051 \\
\hline & $(0.086)$ & $(0.087)$ & $(0.087)$ & $(0.086)$ & $(0.088)$ & $(0.086)$ & $(0.086)$ & $(0.088)$ & $(0.087)$ \\
\hline \multirow[t]{2}{*}{ College_graduate } & 0.052 & 0.054 & 0.068 & 0.067 & 0.067 & 0.066 & 0.059 & 0.078 & 0.098 \\
\hline & $(0.087)$ & $(0.089)$ & $(0.088)$ & $(0.087)$ & $(0.089)$ & (0.088) & $(0.087)$ & $(0.090)$ & (0.089) \\
\hline \multirow[t]{2}{*}{ Middle wealth } & -0.108 & -0.108 & -0.103 & -0.101 & -0.103 & -0.114 & -0.101 & -0.105 & -0.112 \\
\hline & $(0.053)^{\star \star}$ & $(0.054)^{\star \star}$ & $(0.053)^{\star}$ & $(0.054)^{\star}$ & $(0.054)^{\star}$ & $(0.053)^{\star \star}$ & $(0.054)^{*}$ & $(0.054)^{\star}$ & $(0.053)^{\star \star}$ \\
\hline \multirow[t]{3}{*}{ High wealth } & -0.072 & -0.072 & -0.060 & -0.067 & -0.063 & -0.090 & -0.061 & -0.072 & -0.078 \\
\hline & $(0.059)$ & $(0.059)$ & (0.059) & $(0.059)$ & $(0.059)$ & $(0.059)$ & $(0.059)$ & $(0.061)$ & $(0.060)$ \\
\hline & & & 73 & & & & & & \\
\hline
\end{tabular}




\begin{tabular}{|c|c|c|c|c|c|c|c|c|c|}
\hline \multirow[b]{2}{*}{ VARIABLES } & (1) & (2) & (3) & (4) & (5) & (6) & (7) & (8) & (9) \\
\hline & \multicolumn{9}{|c|}{ Retired after Full Retirement Age } \\
\hline \multirow[t]{2}{*}{ Excellent or very good health } & -0.088 & -0.087 & -0.082 & -0.084 & -0.083 & -0.072 & -0.085 & -0.068 & -0.069 \\
\hline & $(0.044)^{\star *}$ & $(0.045)^{\star}$ & $(0.045)^{\star}$ & $(0.045)^{\star}$ & $(0.045)^{\star}$ & $(0.044)$ & $(0.044)^{\star}$ & $(0.045)$ & $(0.045)$ \\
\hline \multirow[t]{2}{*}{ Fair or poor health } & -0.114 & -0.115 & -0.114 & -0.114 & -0.115 & -0.116 & -0.106 & -0.108 & -0.092 \\
\hline & $(0.065)^{\star}$ & $(0.065)^{\star}$ & $(0.064)^{\star}$ & $(0.065)^{\star}$ & $(0.064)^{\star}$ & $(0.065)^{\star}$ & $(0.065)$ & $(0.064)^{\star}$ & $(0.063)$ \\
\hline \multirow[t]{2}{*}{ Missing indicator: Cognitive abilities } & & 0.012 & -1.168 & -0.566 & -1.175 & & & -0.961 & -0.779 \\
\hline & & $(0.547)$ & $(0.573)^{\star \star}$ & $(0.564)$ & $(0.774)$ & & & $(0.794)$ & $(0.786)$ \\
\hline \multirow[t]{2}{*}{ Missing indicator: Future time perspective } & & & & & & -0.140 & & -0.120 & -0.115 \\
\hline & & & & & & $(0.147)$ & & $(0.145)$ & $(0.141)$ \\
\hline \multirow[t]{2}{*}{ Missing indicator: Social Security expectations } & & & & & & & 0.269 & 0.262 & 0.264 \\
\hline & & & & & & & $(0.297)$ & $(0.291)$ & $(0.311)$ \\
\hline \multirow[t]{2}{*}{ Missing indicator: Wealth } & -0.069 & -0.066 & -0.036 & -0.059 & -0.033 & -0.073 & -0.062 & -0.038 & -0.058 \\
\hline & $(0.132)$ & $(0.133)$ & $(0.134)$ & $(0.133)$ & $(0.135)$ & $(0.137)$ & $(0.134)$ & $(0.141)$ & $(0.142)$ \\
\hline \multirow[t]{2}{*}{ Constant } & 0.380 & 0.380 & 1.539 & 0.946 & 1.553 & 0.578 & 0.402 & 1.525 & 1.364 \\
\hline & $(0.090)^{\star \star \star}$ & $(0.531)$ & $(0.563)^{\star \star \star}$ & $(0.560)^{\star}$ & $(0.757)^{\star \star}$ & $(0.164)^{\star \star \star}$ & $(0.096)^{\star \star \star}$ & $(0.766)^{\star \star}$ & $(0.759)^{\star}$ \\
\hline Observations & 532 & 532 & 532 & 532 & 532 & 532 & 532 & 532 & 532 \\
\hline
\end{tabular}

* Two-sided $p$-value <.10; ** $p<.05 ;$ *** $p<.01$.

NOTE: Numbers reported are regression coefficients, with standard errors in parentheses. 
Table B7c. Retired After the Full Retirement Age

\begin{tabular}{|c|c|c|c|c|c|c|}
\hline \multirow[b]{2}{*}{ VARIABLES } & (1) & (2) & (3) & (4) & (5) & (6) \\
\hline & \multicolumn{6}{|c|}{ Retired after Full Retirement Age } \\
\hline \multirow[t]{2}{*}{ Financial literacy index } & -0.007 & -0.009 & -0.013 & & & \\
\hline & $(0.016)$ & $(0.020)$ & $(0.020)$ & & & \\
\hline \multirow[t]{2}{*}{$\begin{array}{l}\text { Maximizing: having high } \\
\text { standards }\end{array}$} & & & & -0.026 & -0.029 & -0.022 \\
\hline & & & & $(0.024)$ & $(0.025)$ & $(0.025)$ \\
\hline \multirow[t]{2}{*}{ Maximizing: continual search } & & & & -0.020 & -0.019 & -0.011 \\
\hline & & & & $(0.025)$ & $(0.027)$ & $(0.026)$ \\
\hline \multirow[t]{2}{*}{ Maximizing: decision difficulty } & & & & 0.025 & 0.023 & 0.019 \\
\hline & & & & $(0.023)$ & $(0.023)$ & $(0.023)$ \\
\hline \multirow[t]{2}{*}{ Age 65 to 69} & & & -0.174 & & & -0.165 \\
\hline & & & $(0.050)^{\star \star \star}$ & & & $(0.050)^{\star \star \star}$ \\
\hline \multirow[t]{2}{*}{ Male } & & 0.037 & 0.012 & & 0.033 & 0.000 \\
\hline & & $(0.053)$ & $(0.053)$ & & $(0.054)$ & $(0.055)$ \\
\hline \multirow[t]{2}{*}{ Married } & & -0.023 & 0.004 & & 0.005 & 0.039 \\
\hline & & $(0.062)$ & $(0.061)$ & & $(0.066)$ & $(0.064)$ \\
\hline \multirow[t]{2}{*}{ Divorced } & & -0.055 & -0.007 & & -0.030 & 0.012 \\
\hline & & $(0.079)$ & $(0.078)$ & & $(0.082)$ & $(0.080)$ \\
\hline \multirow[t]{2}{*}{ High school graduate } & & 0.094 & 0.094 & & 0.126 & 0.117 \\
\hline & & $(0.118)$ & $(0.116)$ & & $(0.129)$ & $(0.125)$ \\
\hline \multirow[t]{2}{*}{ At least some college } & & 0.085 & 0.108 & & 0.068 & 0.090 \\
\hline & & $(0.121)$ & $(0.120)$ & & $(0.128)$ & $(0.124)$ \\
\hline \multirow[t]{2}{*}{ College_graduate } & & 0.091 & 0.125 & & 0.080 & 0.102 \\
\hline & & $(0.125)$ & $(0.124)$ & & $(0.129)$ & $(0.126)$ \\
\hline \multirow[t]{2}{*}{ Middle wealth } & & -0.107 & -0.109 & & -0.157 & -0.154 \\
\hline & & $(0.071)$ & $(0.070)$ & & $(0.074)^{\star \star}$ & $(0.072)^{\star \star}$ \\
\hline \multirow[t]{2}{*}{ High wealth } & & -0.040 & -0.039 & & -0.054 & -0.045 \\
\hline & & $(0.080)$ & $(0.079)$ & & $(0.082)$ & $(0.080)$ \\
\hline \multirow[t]{2}{*}{ Excellent or very good health } & & -0.036 & -0.027 & & -0.023 & -0.015 \\
\hline & & $(0.054)$ & $(0.054)$ & & $(0.057)$ & $(0.056)$ \\
\hline \multirow[t]{2}{*}{ Fair or poor health } & & -0.073 & -0.065 & & -0.042 & -0.027 \\
\hline & & $(0.085)$ & $(0.083)$ & & $(0.100)$ & $(0.099)$ \\
\hline \multirow[t]{2}{*}{ Missing indicator: Wealth } & & 0.067 & 0.015 & & 0.016 & 0.023 \\
\hline & & $(0.202)$ & $(0.211)$ & & $(0.203)$ & $(0.203)$ \\
\hline \multirow[t]{2}{*}{ Constant } & 0.303 & 0.306 & 0.342 & 0.382 & 0.400 & 0.384 \\
\hline & $(0.027)^{\star \star \star}$ & $(0.125)^{\star \star}$ & $(0.125)^{\star \star \star}$ & $(0.140)^{\star \star \star}$ & $(0.193)^{\star \star}$ & $(0.186)^{\star \star}$ \\
\hline Observations & 352 & 352 & 352 & 327 & 327 & 327 \\
\hline
\end{tabular}

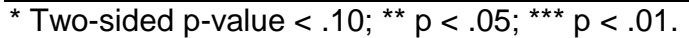

NOTE: Numbers reported are regression coefficients, with standard errors in parentheses. 


\section{Whether Retirement Age Was As Expected}

Table B8a. Retired Earlier Than Expected

$\begin{array}{lllll}(1) & (2) & \begin{array}{l}(3) \\ \text { Retired earlier than expected }\end{array}\end{array}$

VARIABLES

Retired earlier than expected

Cognitive ability: Number series

0.000392

(0.001)

0.000305

(0.002)

Cognitive ability: Picture vocabulary

$-0.001381$

$-0.002055$

(0.001)

Cognitive ability: Verbal

analogies

$(0.001)$

$0.001539 \quad 0.002071$
0.000157

(0.002)

$-0.001523$

(0.001)

0.001740

(0.001) (0.001)

0.057016

(0.001)

0.054348

$(0.023)^{\star \star}$

$(0.023)^{\star \star}$

0.030307

0.037173

(0.026)

(0.026)

$0.000967 \quad 0.001140$

(0.001)

(0.001)

$\begin{array}{cccc}0.534435 & -0.447364 & 1.132294 & 0.422118 \\ (0.738) & (0.721) & (0.691) & (0.962)\end{array}$

$(0.738)$

(0.721)

(0.691)

(0.962)

(0.959)

Missing indicator: Future time perspective

0.537965

$(0.183)^{\star \star \star}$

0.503565

$(0.184)^{\star \star \star}$

\begin{tabular}{lccccccc}
\hline Constant & 0.340565 & 1.322364 & -0.257294 & 0.452882 & 0.150924 & 0.498926 & -0.031299 \\
& $(0.729)$ & $(0.711)^{\star}$ & $(0.681)$ & $(0.955)$ & $(0.169)$ & $(0.067)^{\star \star \star}$ & $(0.969)$ \\
\hline Observations & 303 & 303 & 303 & 303 & 303 & 303 & 303 \\
\hline
\end{tabular}

* Two-sided p-value <.10; ** $p<.05 ;{ }^{* \star *} p<.01$.

NOTE: Numbers reported are regression coefficients, with standard errors in parentheses. 
Table B8b. Retired Earlier Than Expected

\begin{tabular}{|c|c|c|c|c|c|c|c|c|c|}
\hline \multirow[b]{2}{*}{ VARIABLES } & (1) & (2) & (3) & (4) & (5) & (6) & (7) & (8) & (9) \\
\hline & \multicolumn{9}{|c|}{ Retired earlier than expected } \\
\hline Cognitive ability: Number series & & $\begin{array}{l}0.002814 \\
(0.001)^{\star \star}\end{array}$ & & & $\begin{array}{c}0.002064 \\
(0.002)\end{array}$ & & & $\begin{array}{l}0.001933 \\
(0.002)\end{array}$ & $\begin{array}{c}0.002197 \\
(0.002)\end{array}$ \\
\hline $\begin{array}{l}\text { Cognitive ability: Picture } \\
\text { vocabulary }\end{array}$ & & & $\begin{array}{c}0.000166 \\
(0.001)\end{array}$ & & $\begin{array}{c}-0.000952 \\
(0.001)\end{array}$ & & & $\begin{array}{c}-0.000491 \\
(0.001)\end{array}$ & $\begin{array}{c}-0.000087 \\
(0.001)\end{array}$ \\
\hline $\begin{array}{l}\text { Cognitive ability: Verbal } \\
\text { analogies }\end{array}$ & & & & $\begin{array}{l}0.003204 \\
(0.001)^{\star *}\end{array}$ & $\begin{array}{c}0.002780 \\
(0.001)^{\star}\end{array}$ & & & $\begin{array}{c}0.002431 \\
(0.001)^{*}\end{array}$ & $\begin{array}{c}0.001961 \\
(0.001)\end{array}$ \\
\hline Focus on opportunities & & & & & & $\begin{array}{l}0.058050 \\
(0.023)^{\star \star}\end{array}$ & & $\begin{array}{l}0.053694 \\
(0.023)^{\star \star}\end{array}$ & $\begin{array}{c}0.033227 \\
(0.024)\end{array}$ \\
\hline Focus on limitations & & & & & & $\begin{array}{c}0.031092 \\
(0.026)\end{array}$ & & $\begin{array}{c}0.027215 \\
(0.026)\end{array}$ & $\begin{array}{c}0.042791 \\
(0.026)\end{array}$ \\
\hline Social Security expectations & & & & & & & $\begin{array}{l}0.001306 \\
(0.001)\end{array}$ & $\begin{array}{c}0.001287 \\
(0.001)\end{array}$ & $\begin{array}{c}0.000916 \\
(0.001) \\
0.309283\end{array}$ \\
\hline Age 45 to 49 & & & & & & & & & $(0.150)^{\star \star}$ \\
\hline Age 50 to 54 & & & & & & & & & $\begin{array}{l}0.283759 \\
(0.130)^{\star *}\end{array}$ \\
\hline Age 55 to 59 & & & & & & & & & $\begin{array}{l}0.275310 \\
(0.105)^{\star \star \star}\end{array}$ \\
\hline Age 60 to 64 & & & & & & & & & $\begin{array}{c}0.184623 \\
(0.097)^{\star}\end{array}$ \\
\hline Age 65 to 69 & & & & & & & & & $\begin{array}{c}0.002944 \\
(0.098)\end{array}$ \\
\hline Male & $\begin{array}{c}0.007698 \\
(0.058)\end{array}$ & $\begin{array}{c}-0.009931 \\
(0.058)\end{array}$ & $\begin{array}{c}0.007385 \\
(0.058)\end{array}$ & $\begin{array}{c}0.020293 \\
(0.059)\end{array}$ & $\begin{array}{c}0.005356 \\
(0.060)\end{array}$ & $\begin{array}{c}-0.001131 \\
(0.057)\end{array}$ & $\begin{array}{c}0.004047 \\
(0.057)\end{array}$ & $\begin{array}{l}-0.007970 \\
(0.059)\end{array}$ & $\begin{array}{c}-0.023231 \\
(0.059)\end{array}$ \\
\hline Married & $\begin{array}{c}-0.130056 \\
(0.076)^{\star}\end{array}$ & $\begin{array}{l}-0.149119 \\
(0.075)^{\star \star}\end{array}$ & $\begin{array}{c}-0.133361 \\
(0.077)^{\star}\end{array}$ & $\begin{array}{c}-0.156834 \\
(0.074)^{\star \star}\end{array}$ & $\begin{array}{c}-0.160637 \\
(0.074)^{\star \star}\end{array}$ & $\begin{array}{c}-0.116401 \\
(0.075)\end{array}$ & $\begin{array}{c}-0.132463 \\
(0.077)^{\star}\end{array}$ & $\begin{array}{l}-0.148311 \\
(0.074)^{\star \star}\end{array}$ & $\begin{array}{l}-0.175759 \\
(0.072)^{\star \star}\end{array}$ \\
\hline Divorced & $\begin{array}{c}-0.028633 \\
(0.095)\end{array}$ & $\begin{array}{c}-0.034568 \\
(0.093)\end{array}$ & $\begin{array}{c}-0.027690 \\
(0.095)\end{array}$ & $\begin{array}{c}-0.051144 \\
(0.092)\end{array}$ & $\begin{array}{c}-0.053181 \\
(0.091)\end{array}$ & $\begin{array}{c}-0.020721 \\
(0.094)\end{array}$ & $\begin{array}{c}-0.031658 \\
(0.095)\end{array}$ & $\begin{array}{c}-0.044219 \\
(0.091)\end{array}$ & $\begin{array}{c}-0.016445 \\
(0.090)\end{array}$ \\
\hline
\end{tabular}




\section{(1)}

(2)

(3)

(4)

(5)

(6)

(7)

(8)

(9)

VARIABLES

Retired earlier than expected

High school graduate

$\begin{array}{lllllllll}-0.210102 & -0.182423 & -0.179464 & -0.202386 & -0.193825 & -0.196833 & -0.218075 & -0.185442 & -0.222738\end{array}$

$\begin{array}{lllllllll}(0.109)^{*} & (0.111) & (0.112) & (0.111)^{\star} & (0.112)^{*} & (0.100)^{*} & (0.109)^{\star \star} & (0.102)^{\star} & (0.107)^{\star \star}\end{array}$

At least some college

$\begin{array}{lllll}-0.182618 & -0.145633 & -0.149651 & -0.167877 & -0.155018\end{array}$

$-0.186455-0.183485$

College_graduate

$-0.178499$

0.174606

$10.109)$

$-0.199500$

$(0.097)^{\star}$

$(0.109)^{*}$

$(0.099)$

$(0.106)^{\star \star}$

$(0.106)$

$(0.107)$

(0.108)

$(0.107)^{\star}$

$(0.107)^{\star}$

0.199730

$-0.182469$

$-0.219508$

$-0.270438$

$\begin{array}{llll}-0.019895 & -0.051962 & -0.026373 & -0.045087\end{array}$

(0.075)

(0.074)

$(0.075)$

(0.074)

$-0.055455$

0.005206

$(0.106)^{\star}$

$(0.096)^{\star *}$

$(0.100)^{\star \star \star}$

$\begin{array}{llll}-0.196717 & -0.241468 & -0.204435 & -0.225733\end{array}$

(0.075)

(0.074)

$-0.02901$

$-0.037966 \quad-0.049436$

High wealth

$(0.075)^{\star \star \star}$

$(0.078)^{\star \star \star}$

$(0.076)^{\star \star \star}$

$(0.076)^{\star \star \star}$

$-0.240536$

$-0.158189$

$(0.075)$

(0.075)

(0.074)

Excellent or very good health

0.026171

0.035978

0.031148

0.023153

$(0.079)^{\star \star \star}$

$(0.076)^{\star \star}$

$-0.204735$

$-0.209390$

$-0.218831$$$
\text { (0.064) }
$$

(0.064)

(0.064)

0.025284

0.011190

$(0.075)^{\star \star \star}$

$(0.081)^{\star *}$

$(0.081)^{\star \star \star}$

0.240598

$0.242138 \quad 0.231639$

0.233738

$(0.064)$

(0.065)

0.023432

0.011565

0.018311

$(0.084)^{\star \star \star}$

$(0.086)^{\star \star \star}$

$(0.085)^{\star \star \star}$

$(0.085)^{\star \star \star}$

0.236947

0.246751

$(0.064)$

(0.064)

$(0.063)$

$\begin{array}{llll}1.750164 & 0.341470 & 1.922121 & 2.270960\end{array}$

$(0.087)^{\star \star \star} \quad(0.084)^{\star \star \star}$

0.244491

0.206202

Missing indicator: Cognitive abilities

$$
(0.732)^{\star \star} \quad(0.731) \quad(0.689)^{\star \star \star} \quad(0.974)^{\star \star}
$$

Missing indicator: Future time perspective

\begin{tabular}{lccccccccc} 
& & & & & & $(0.187)^{\star \star \star}$ & $(0.192)^{\star \star}$ & $(0.191)^{\star \star}$ \\
Missing indicator: Wealth & 0.063378 & 0.027879 & 0.068074 & 0.062604 & 0.043953 & 0.059692 & 0.053662 & 0.036582 & 0.003803 \\
& $(0.177)$ & $(0.179)$ & $(0.179)$ & $(0.169)$ & $(0.169)$ & $(0.174)$ & $(0.182)$ & $(0.171)$ & $(0.166)$ \\
\hline Constant & 0.845119 & -0.633692 & 0.724546 & -0.799691 & -1.131715 & 0.449071 & 0.780506 & -1.573898 & -1.737469 \\
& $(0.128)^{\star \star \star}$ & $(0.711)$ & $(0.718)$ & $(0.676)$ & $(0.947)$ & $(0.214)^{\star \star}$ & $(0.136)^{\star \star \star}$ & $(0.963)$ & $(0.927)^{\star}$ \\
\hline Observations & 303 & 303 & 303 & 303 & 303 & 303 & 303 & 303 & 303 \\
\hline
\end{tabular}

* Two-sided $p$-value $<.10 ;{ }^{* \star} p<.05 ;{ }^{* \star *} p<.01$.

NOTE: Numbers reported are regression coefficients, with standard errors in parentheses. 
Table B8c. Retired Earlier Than Expected

\begin{tabular}{|c|c|c|c|c|c|c|}
\hline \multirow[b]{2}{*}{ VARIABLES } & (1) & (2) & (3) & (4) & (5) & (6) \\
\hline & \multicolumn{6}{|c|}{ Retired earlier than expected } \\
\hline Financial literacy index & $\begin{array}{c}-0.042542 \\
(0.020)^{\star \star}\end{array}$ & $\begin{array}{c}-0.021090 \\
(0.022)\end{array}$ & $\begin{array}{c}-0.020205 \\
(0.022)\end{array}$ & & & \\
\hline $\begin{array}{l}\text { Maximizing: having high } \\
\text { standards }\end{array}$ & & & & $\begin{array}{c}-0.019904 \\
(0.031)\end{array}$ & $\begin{array}{c}0.000771 \\
(0.030)\end{array}$ & $\begin{array}{c}-0.004345 \\
(0.030)\end{array}$ \\
\hline Maximizing: continual search & & & & $\begin{array}{c}0.004055 \\
(0.037)\end{array}$ & $\begin{array}{c}-0.009855 \\
(0.036)\end{array}$ & $\begin{array}{c}-0.020003 \\
(0.035)\end{array}$ \\
\hline Maximizing: decision difficulty & & & & $\begin{array}{c}-0.034673 \\
(0.029)\end{array}$ & $\begin{array}{c}-0.032609 \\
(0.027)\end{array}$ & $\begin{array}{c}-0.028093 \\
(0.026)\end{array}$ \\
\hline Age 45 to 49 & & & $\begin{array}{c}0.110376 \\
(0.249)\end{array}$ & & & $\begin{array}{c}0.299807 \\
(0.396)\end{array}$ \\
\hline Age 50 to 54 & & & $\begin{array}{l}0.374885 \\
(0.161)^{\star \star}\end{array}$ & & & $\begin{array}{l}0.371479 \\
(0.183)^{\star \star}\end{array}$ \\
\hline Age 55 to 59 & & & $\begin{array}{l}0.264009 \\
(0.120)^{\star \star}\end{array}$ & & & $\begin{array}{l}0.313820 \\
(0.129)^{\star \star}\end{array}$ \\
\hline Age 60 to 64 & & & $\begin{array}{c}0.215687 \\
(0.116)^{\star}\end{array}$ & & & $\begin{array}{c}0.237605 \\
(0.125)^{\star}\end{array}$ \\
\hline Age 65 to 69 & & & $\begin{array}{c}-0.015422 \\
(0.115)\end{array}$ & & & $\begin{array}{c}-0.004981 \\
(0.129)\end{array}$ \\
\hline Male & & $\begin{array}{c}-0.013805 \\
(0.072)\end{array}$ & $\begin{array}{c}-0.019862 \\
(0.070)\end{array}$ & & $\begin{array}{c}0.000527 \\
(0.080)\end{array}$ & $\begin{array}{c}-0.004509 \\
(0.079)\end{array}$ \\
\hline Married & & $\begin{array}{l}-0.288055 \\
(0.092)^{\star \star \star}\end{array}$ & $\begin{array}{l}-0.333423 \\
(0.095)^{\star \star \star}\end{array}$ & & $\begin{array}{l}-0.294268 \\
(0.112)^{\star \star \star}\end{array}$ & $\begin{array}{l}-0.324391 \\
(0.115)^{\star \star \star}\end{array}$ \\
\hline Divorced & & $\begin{array}{c}-0.246780 \\
(0.113)^{\star \star}\end{array}$ & $\begin{array}{c}-0.228030 \\
(0.114)^{\star \star}\end{array}$ & & $\begin{array}{c}-0.211218 \\
(0.136)\end{array}$ & $\begin{array}{c}-0.174742 \\
(0.135)\end{array}$ \\
\hline High school graduate & & $\begin{array}{c}-0.165414 \\
(0.148)\end{array}$ & $\begin{array}{c}-0.241734 \\
(0.167)\end{array}$ & & $\begin{array}{c}-0.088561 \\
(0.184)\end{array}$ & $\begin{array}{c}-0.193846 \\
(0.212)\end{array}$ \\
\hline At least some college & & $\begin{array}{c}-0.143069 \\
(0.148)\end{array}$ & $\begin{array}{c}-0.230127 \\
(0.170)\end{array}$ & & $\begin{array}{c}-0.145314 \\
(0.186)\end{array}$ & $\begin{array}{c}-0.285766 \\
(0.218)\end{array}$ \\
\hline College_graduate & & $\begin{array}{c}-0.142270 \\
(0.150)\end{array}$ & $\begin{array}{c}-0.231876 \\
(0.168)\end{array}$ & & $\begin{array}{c}-0.116559 \\
(0.190)\end{array}$ & $\begin{array}{c}-0.253533 \\
(0.220)\end{array}$ \\
\hline Middle wealth & & $\begin{array}{c}-0.054743 \\
(0.096)\end{array}$ & $\begin{array}{c}-0.021031 \\
(0.098)\end{array}$ & & $\begin{array}{c}-0.129882 \\
(0.106)\end{array}$ & $\begin{array}{c}-0.117859 \\
(0.106)\end{array}$ \\
\hline High wealth & & $\begin{array}{c}-0.175977 \\
(0.102)^{\star}\end{array}$ & $\begin{array}{c}-0.150765 \\
(0.102)\end{array}$ & & $\begin{array}{c}-0.238932 \\
(0.105)^{\star \star}\end{array}$ & $\begin{array}{c}-0.211861 \\
(0.104)^{\star *}\end{array}$ \\
\hline Excellent or very good health & & $\begin{array}{c}0.018338 \\
(0.077)\end{array}$ & $\begin{array}{c}0.002657 \\
(0.076)\end{array}$ & & $\begin{array}{c}-0.024612 \\
(0.081)\end{array}$ & $\begin{array}{c}-0.028826 \\
(0.081)\end{array}$ \\
\hline Fair or poor health & & $\begin{array}{l}0.308772 \\
(0.102)^{\star \star \star}\end{array}$ & $\begin{array}{l}0.270156 \\
(0.109)^{\star \star}\end{array}$ & & $\begin{array}{l}0.349916 \\
(0.106)^{\star \star \star}\end{array}$ & $\begin{array}{l}0.329042 \\
(0.112)^{\star \star \star}\end{array}$ \\
\hline
\end{tabular}


(1)

(2)

(3)

(4)

(5)

(6)

VARIABLES

Retired earlier than expected

\begin{tabular}{lcccccc} 
Missing indicator: Wealth & & $\begin{array}{c}0.107018 \\
(0.225)\end{array}$ & $\begin{array}{c}0.176300 \\
(0.216)\end{array}$ & $\begin{array}{c}-0.094062 \\
(0.209)\end{array}$ & $\begin{array}{c}-0.070481 \\
(0.188)\end{array}$ \\
\hline Constant & 0.529335 & 0.947048 & 0.872819 & 0.698817 & 1.119679 & 1.090333 \\
& $(0.035)^{\star \star \star}$ & $(0.173)^{\star \star \star}$ & $(0.190)^{\star \star \star}$ & $(0.179)^{\star \star \star}$ & $(0.273)^{\star \star \star}$ & $(0.294)^{\star \star \star}$ \\
\hline Observations & 209 & 209 & 209 & 188 & 188 & 188 \\
\hline
\end{tabular}

${ }^{*}$ Two-sided $p$-value $<.10 ; * \star p<.05 ;{ }^{* \star \star} p<.01$.

NOTE: Numbers reported are regression coefficients, with standard errors in parentheses. 
Table B9a. Retired About When Expected

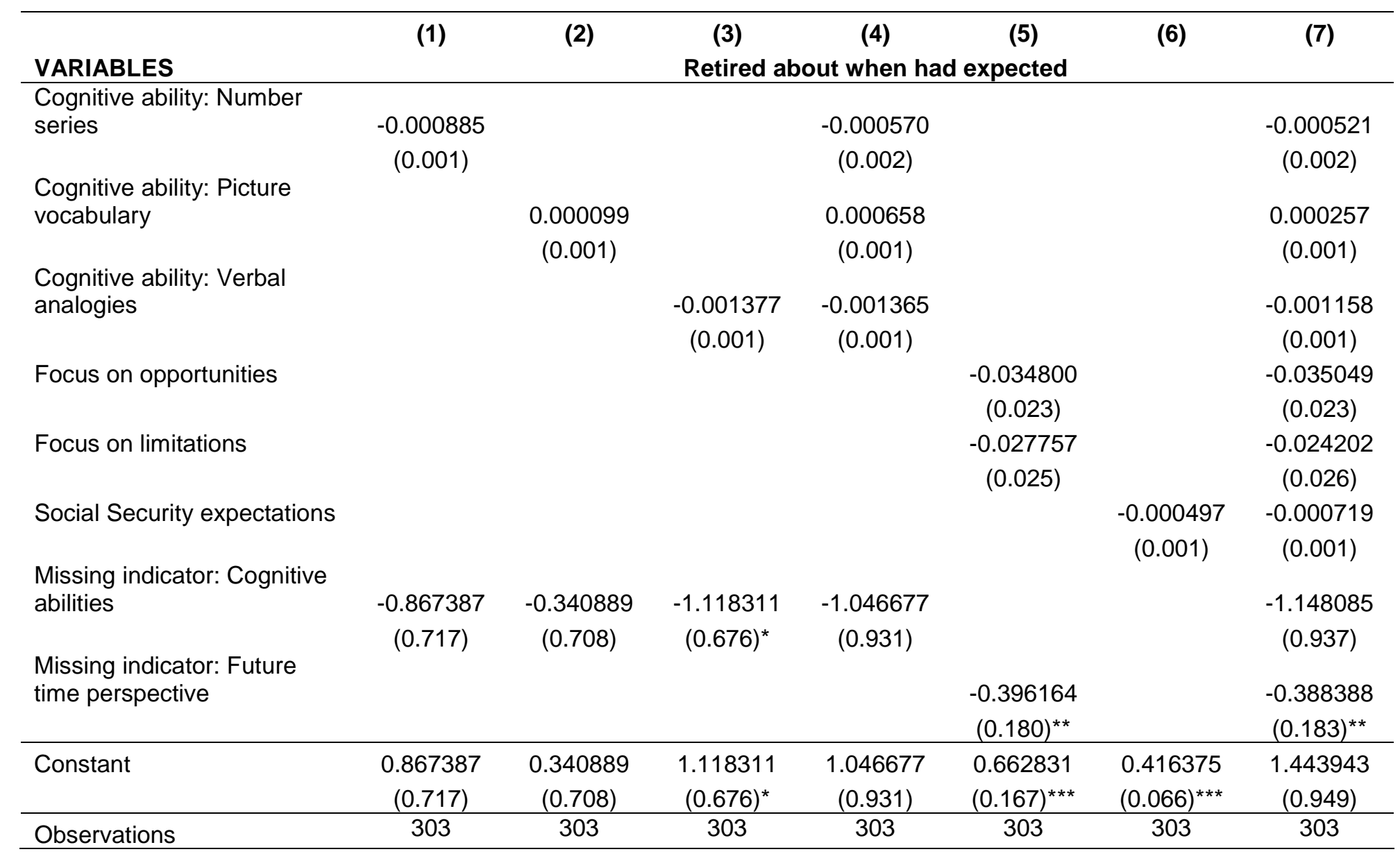

* Two-sided $p$-value $<.10 ;$ ** $p<.05 ;$ *** $p<.01$.

NOTE: Numbers reported are regression coefficients, with standard errors in parentheses. 
Table B9b. Retired About When Expected

\begin{tabular}{|c|c|c|c|c|c|c|c|c|c|}
\hline & (1) & (2) & (3) & (4) & (5) & (6) & (7) & (8) & (9) \\
\hline VARIABLES & & & & Retired al & ut when ha & expected & & & \\
\hline $\begin{array}{l}\text { Cognitive ability: Number } \\
\text { series }\end{array}$ & & $\begin{array}{l}-0.003195 \\
(0.001)^{\star \star}\end{array}$ & & & $\begin{array}{c}-0.002421 \\
(0.002)\end{array}$ & & & $\begin{array}{c}-0.002402 \\
(0.002)\end{array}$ & $\begin{array}{c}-0.002550 \\
(0.002)\end{array}$ \\
\hline $\begin{array}{l}\text { Cognitive ability: Picture } \\
\text { vocabulary }\end{array}$ & & & $\begin{array}{c}-0.001202 \\
(0.001)\end{array}$ & & $\begin{array}{c}-0.000205 \\
(0.001)\end{array}$ & & & $\begin{array}{c}-0.000562 \\
(0.001)\end{array}$ & $\begin{array}{c}-0.000837 \\
(0.001)\end{array}$ \\
\hline $\begin{array}{l}\text { Cognitive ability: Verbal } \\
\text { analogies }\end{array}$ & & & & $\begin{array}{l}-0.002738 \\
(0.001)^{\star *}\end{array}$ & $\begin{array}{c}-0.001887 \\
(0.001)\end{array}$ & & & $\begin{array}{c}-0.001629 \\
(0.001)\end{array}$ & $\begin{array}{c}-0.001503 \\
(0.001)\end{array}$ \\
\hline Focus on opportunities & & & & & & $\begin{array}{c}-0.034871 \\
(0.023)\end{array}$ & & $\begin{array}{c}-0.033217 \\
(0.024)\end{array}$ & $\begin{array}{c}-0.023957 \\
(0.025)\end{array}$ \\
\hline Focus on limitations & & & & & & $\begin{array}{c}-0.023067 \\
(0.026)\end{array}$ & & $\begin{array}{c}-0.023566 \\
(0.026)\end{array}$ & $\begin{array}{c}-0.028640 \\
(0.027)\end{array}$ \\
\hline Social Security expectations & & & & & & & $\begin{array}{c}-0.000811 \\
(0.001)\end{array}$ & $\begin{array}{c}-0.000911 \\
(0.001)\end{array}$ & $\begin{array}{c}-0.000812 \\
(0.001)\end{array}$ \\
\hline Age 45 to 49 & & & & & & & & & $\begin{array}{c}-0.113850 \\
(0.156)\end{array}$ \\
\hline Age 50 to 54 & & & & & & & & & $\begin{array}{c}-0.087929 \\
(0.137)\end{array}$ \\
\hline Age 55 to 59 & & & & & & & & & $\begin{array}{c}-0.058017 \\
(0.117)\end{array}$ \\
\hline Age 60 to 64 & & & & & & & & & $\begin{array}{c}0.028472 \\
(0.108)\end{array}$ \\
\hline Age 65 to 69 & & & & & & & & & $\begin{array}{c}0.055853 \\
(0.111)\end{array}$ \\
\hline Male & $\begin{array}{l}0.039135 \\
(0.058)\end{array}$ & $\begin{array}{l}0.059280 \\
(0.058)\end{array}$ & $\begin{array}{l}0.038995 \\
(0.058)\end{array}$ & $\begin{array}{c}0.028615 \\
(0.059)\end{array}$ & $\begin{array}{l}0.046754 \\
(0.060)\end{array}$ & $\begin{array}{l}0.047769 \\
(0.058)\end{array}$ & $\begin{array}{c}0.041401 \\
(0.058)\end{array}$ & $\begin{array}{l}0.059485 \\
(0.060)\end{array}$ & $\begin{array}{c}0.063869 \\
(0.060)\end{array}$ \\
\hline
\end{tabular}




\begin{tabular}{|c|c|c|c|c|c|c|c|c|c|}
\hline \multirow[b]{2}{*}{ VARIABLES } & (1) & (2) & (3) & (4) & (5) & (6) & (7) & (8) & (9) \\
\hline & \multicolumn{9}{|c|}{ Retired about when had expected } \\
\hline Married & $\begin{array}{c}0.125737 \\
(0.075)^{\star}\end{array}$ & $\begin{array}{l}0.148119 \\
(0.073)^{\star \star}\end{array}$ & $\begin{array}{c}0.135760 \\
(0.076)^{\star}\end{array}$ & $\begin{array}{l}0.150031 \\
(0.074)^{\star \star}\end{array}$ & $\begin{array}{l}0.159020 \\
(0.074)^{\star \star}\end{array}$ & $\begin{array}{c}0.114269 \\
(0.075)\end{array}$ & $\begin{array}{c}0.127231 \\
(0.076)^{\star}\end{array}$ & $\begin{array}{l}0.148554 \\
(0.075)^{\star \star}\end{array}$ & $\begin{array}{c}0.145226 \\
(0.075)^{\star}\end{array}$ \\
\hline Divorced & $\begin{array}{c}0.014965 \\
(0.092)\end{array}$ & $\begin{array}{c}0.021421 \\
(0.089)\end{array}$ & $\begin{array}{c}0.013499 \\
(0.092)\end{array}$ & $\begin{array}{c}0.033660 \\
(0.090)\end{array}$ & $\begin{array}{c}0.033319 \\
(0.089)\end{array}$ & $\begin{array}{c}0.006232 \\
(0.092)\end{array}$ & $\begin{array}{c}0.016843 \\
(0.093)\end{array}$ & $\begin{array}{c}0.023620 \\
(0.090)\end{array}$ & $\begin{array}{c}0.004567 \\
(0.090)\end{array}$ \\
\hline High school graduate & $\begin{array}{c}0.158448 \\
(0.111)\end{array}$ & $\begin{array}{c}0.117176 \\
(0.112)\end{array}$ & $\begin{array}{c}0.122973 \\
(0.113)\end{array}$ & $\begin{array}{c}0.132984 \\
(0.112)\end{array}$ & $\begin{array}{c}0.132193 \\
(0.113)\end{array}$ & $\begin{array}{c}0.146920 \\
(0.104)\end{array}$ & $\begin{array}{c}0.163398 \\
(0.110)\end{array}$ & $\begin{array}{c}0.125073 \\
(0.105)\end{array}$ & $\begin{array}{c}0.127629 \\
(0.107)\end{array}$ \\
\hline At least some college & $\begin{array}{c}0.141451 \\
(0.109)\end{array}$ & $\begin{array}{c}0.088910 \\
(0.111)\end{array}$ & $\begin{array}{c}0.102392 \\
(0.112)\end{array}$ & $\begin{array}{c}0.108638 \\
(0.109)\end{array}$ & $\begin{array}{c}0.103019 \\
(0.111)\end{array}$ & $\begin{array}{c}0.145299 \\
(0.100)\end{array}$ & $\begin{array}{c}0.141988 \\
(0.109)\end{array}$ & $\begin{array}{c}0.107704 \\
(0.102)\end{array}$ & $\begin{array}{c}0.115969 \\
(0.107)\end{array}$ \\
\hline College_graduate & $\begin{array}{c}0.156301 \\
(0.106)\end{array}$ & $\begin{array}{c}0.143721 \\
(0.106)\end{array}$ & $\begin{array}{c}0.131864 \\
(0.108)\end{array}$ & $\begin{array}{c}0.159275 \\
(0.106)\end{array}$ & $\begin{array}{c}0.168385 \\
(0.107)\end{array}$ & $\begin{array}{c}0.171234 \\
(0.096)^{\star}\end{array}$ & $\begin{array}{c}0.158766 \\
(0.106)\end{array}$ & $\begin{array}{c}0.184926 \\
(0.098)^{\star}\end{array}$ & $\begin{array}{c}0.188742 \\
(0.101)^{\star}\end{array}$ \\
\hline Middle wealth & $\begin{array}{c}0.033152 \\
(0.073)\end{array}$ & $\begin{array}{c}0.071195 \\
(0.073)\end{array}$ & $\begin{array}{c}0.049192 \\
(0.073)\end{array}$ & $\begin{array}{c}0.057807 \\
(0.073)\end{array}$ & $\begin{array}{c}0.076974 \\
(0.073)\end{array}$ & $\begin{array}{c}0.012714 \\
(0.073)\end{array}$ & $\begin{array}{c}0.038811 \\
(0.074)\end{array}$ & $\begin{array}{c}0.062837 \\
(0.074)\end{array}$ & $\begin{array}{c}0.070527 \\
(0.074)\end{array}$ \\
\hline High wealth & $\begin{array}{c}0.136331 \\
(0.075)^{\star}\end{array}$ & $\begin{array}{l}0.188941 \\
(0.077)^{\star \star}\end{array}$ & $\begin{array}{l}0.158249 \\
(0.076)^{\star \star}\end{array}$ & $\begin{array}{l}0.164570 \\
(0.076)^{\star \star}\end{array}$ & $\begin{array}{l}0.194188 \\
(0.078)^{\star \star}\end{array}$ & $\begin{array}{c}0.105797 \\
(0.078)\end{array}$ & $\begin{array}{c}0.141308 \\
(0.076)^{\star}\end{array}$ & $\begin{array}{l}0.170110 \\
(0.081)^{\star \star}\end{array}$ & $\begin{array}{l}0.189141 \\
(0.082)^{\star \star}\end{array}$ \\
\hline Excellent or very good health & $\begin{array}{c}0.006173 \\
(0.063)\end{array}$ & $\begin{array}{c}-0.006340 \\
(0.063)\end{array}$ & $\begin{array}{c}-0.003795 \\
(0.063)\end{array}$ & $\begin{array}{c}0.006112 \\
(0.063)\end{array}$ & $\begin{array}{c}-0.001048 \\
(0.063)\end{array}$ & $\begin{array}{c}0.011876 \\
(0.064)\end{array}$ & $\begin{array}{c}0.007874 \\
(0.063)\end{array}$ & $\begin{array}{c}0.003260 \\
(0.064)\end{array}$ & $\begin{array}{c}-0.000701 \\
(0.064)\end{array}$ \\
\hline Fair or poor health & $\begin{array}{c}-0.162620 \\
(0.083)^{\star}\end{array}$ & $\begin{array}{c}-0.161374 \\
(0.084)^{\star}\end{array}$ & $\begin{array}{c}-0.154468 \\
(0.084)^{\star}\end{array}$ & $\begin{array}{c}-0.151016 \\
(0.083)^{\star}\end{array}$ & $\begin{array}{c}-0.160997 \\
(0.085)^{\star}\end{array}$ & $\begin{array}{c}-0.166735 \\
(0.085)^{\star}\end{array}$ & $\begin{array}{c}-0.162240 \\
(0.083)^{\star}\end{array}$ & $\begin{array}{c}-0.165623 \\
(0.088)^{\star}\end{array}$ & $\begin{array}{c}-0.148536 \\
(0.090)^{\star}\end{array}$ \\
\hline $\begin{array}{l}\text { Missing indicator: Cognitive } \\
\text { abilities }\end{array}$ & & $\begin{array}{l}-2.063629 \\
(0.714)^{\star \star \star}\end{array}$ & $\begin{array}{l}-1.029669 \\
(0.731)\end{array}$ & $\begin{array}{l}-1.788846 \\
(0.693)^{\star \star}\end{array}$ & $\begin{array}{l}-2.751075 \\
(0.958)^{\star \star \star}\end{array}$ & & & $\begin{array}{l}-2.817071 \\
(0.967)^{\star \star \star}\end{array}$ & $\begin{array}{l}-2.983689 \\
(0.953)^{\star \star \star}\end{array}$ \\
\hline $\begin{array}{l}\text { Missing indicator: Future time } \\
\text { perspective }\end{array}$ & & & & & & $\begin{array}{c}-0.366976 \\
(0.189)^{*}\end{array}$ & & $\begin{array}{c}-0.375725 \\
(0.193)^{\star}\end{array}$ & $\begin{array}{c}-0.350110 \\
(0.195)^{\star}\end{array}$ \\
\hline Missing indicator: Wealth & $\begin{array}{c}-0.188552 \\
(0.145) \\
\end{array}$ & $\begin{array}{c}-0.150282 \\
(0.148) \\
\end{array}$ & $\begin{array}{c}-0.183892 \\
(0.147) \\
\end{array}$ & $\begin{array}{c}-0.191802 \\
(0.142) \\
\end{array}$ & $\begin{array}{c}-0.155060 \\
(0.145) \\
\end{array}$ & $\begin{array}{c}-0.197903 \\
(0.144)\end{array}$ & $\begin{array}{c}-0.182520 \\
(0.149) \\
\end{array}$ & $\begin{array}{c}-0.158459 \\
(0.147) \\
\end{array}$ & $\begin{array}{c}-0.147680 \\
(0.149) \\
\end{array}$ \\
\hline Constant & $\begin{array}{c}0.109658 \\
(0.129) \\
\end{array}$ & $\begin{array}{l}1.798263 \\
(0.697)^{\star \star}\end{array}$ & $\begin{array}{c}0.806445 \\
(0.722) \\
\end{array}$ & $\begin{array}{l}1.533259 \\
(0.686)^{\star \star}\end{array}$ & $\begin{array}{l}2.462502 \\
(0.935)^{\star \star \star}\end{array}$ & $\begin{array}{c}0.381309 \\
(0.223)^{\star}\end{array}$ & $\begin{array}{c}0.149768 \\
(0.135) \\
\end{array}$ & $\begin{array}{l}2.833562 \\
(0.968)^{\star \star \star}\end{array}$ & $\begin{array}{l}2.965373 \\
(0.952)^{\star \star \star}\end{array}$ \\
\hline Observations & 303 & 303 & 303 & 303 & 303 & 303 & 303 & 303 & 303 \\
\hline
\end{tabular}

* Two-sided p-value $<10$ * ** $p<.05 \cdot$ *** $p<01$

NOTE: Numbers reported are regression coefficients, with standard errors in parentheses. 
Table B9c. Retired About When Expected

\begin{tabular}{|c|c|c|c|c|c|c|}
\hline \multirow{3}{*}{$\begin{array}{l}\text { VARIABLES } \\
\text { Financial literacy index }\end{array}$} & (1) & (2) & (3) & (4) & (5 & (6) \\
\hline & \multicolumn{6}{|c|}{ Retired about when had expected } \\
\hline & $\begin{array}{l}0.041558 \\
(0.019)^{\star \star}\end{array}$ & $\begin{array}{c}0.024224 \\
(0.022)\end{array}$ & $\begin{array}{c}0.026060 \\
(0.023)\end{array}$ & & & \\
\hline $\begin{array}{l}\text { Maximizing: having high } \\
\text { standards }\end{array}$ & & & & $\begin{array}{c}0.046941 \\
(0.031)\end{array}$ & $\begin{array}{c}0.029895 \\
(0.031)\end{array}$ & $\begin{array}{c}0.035233 \\
(0.032)\end{array}$ \\
\hline $\begin{array}{l}\text { Maximizing: continual } \\
\text { search }\end{array}$ & & & & $\begin{array}{c}-0.012083 \\
(0.037)\end{array}$ & $\begin{array}{c}-0.002185 \\
(0.037)\end{array}$ & $\begin{array}{c}-0.002789 \\
(0.038)\end{array}$ \\
\hline $\begin{array}{l}\text { Maximizing: decision } \\
\text { difficulty }\end{array}$ & & & & $\begin{array}{c}0.018186 \\
(0.029)\end{array}$ & $\begin{array}{c}0.017135 \\
(0.027)\end{array}$ & $\begin{array}{c}0.015528 \\
(0.027)\end{array}$ \\
\hline Age 45 to 49 & & & $\begin{array}{c}0.115153 \\
(0.224)\end{array}$ & & & $\begin{array}{c}-0.033805 \\
(0.352)\end{array}$ \\
\hline Age 50 to 54 & & & $\begin{array}{c}-0.204036 \\
(0.177)\end{array}$ & & & $\begin{array}{c}-0.189481 \\
(0.204)\end{array}$ \\
\hline Age 55 to 59 & & & $\begin{array}{c}-0.089632 \\
(0.144)\end{array}$ & & & $\begin{array}{c}-0.126065 \\
(0.158)\end{array}$ \\
\hline Age 60 to 64 & & & $\begin{array}{c}-0.052885 \\
(0.139)\end{array}$ & & & $\begin{array}{c}-0.044178 \\
(0.153)\end{array}$ \\
\hline Age 65 to 69 & & & $\begin{array}{c}-0.032219 \\
(0.142)\end{array}$ & & & $\begin{array}{c}-0.049269 \\
(0.161)\end{array}$ \\
\hline Male & & $\begin{array}{c}0.054869 \\
(0.073)\end{array}$ & $\begin{array}{c}0.054736 \\
(0.073)\end{array}$ & & $\begin{array}{c}0.036611 \\
(0.081)\end{array}$ & $\begin{array}{c}0.036793 \\
(0.082)\end{array}$ \\
\hline Married & & $\begin{array}{l}0.276903 \\
(0.087)^{\star \star \star}\end{array}$ & $\begin{array}{l}0.295280 \\
(0.088)^{\star \star \star}\end{array}$ & & $\begin{array}{l}0.279343 \\
(0.108)^{\star \star}\end{array}$ & $\begin{array}{l}0.292236 \\
(0.112)^{\star \star}\end{array}$ \\
\hline Divorced & & $\begin{array}{l}0.203120 \\
(0.106)^{\star}\end{array}$ & $\begin{array}{c}0.209374 \\
(0.108)^{\star}\end{array}$ & & $\begin{array}{c}0.146634 \\
(0.128)\end{array}$ & $\begin{array}{c}0.139082 \\
(0.131)\end{array}$ \\
\hline High school graduate & & $\begin{array}{c}0.093007 \\
(0.149)\end{array}$ & $\begin{array}{c}0.114477 \\
(0.162)\end{array}$ & & $\begin{array}{c}0.012862 \\
(0.187)\end{array}$ & $\begin{array}{c}0.029393 \\
(0.199)\end{array}$ \\
\hline At least some college & & $\begin{array}{c}0.104487 \\
(0.149)\end{array}$ & $\begin{array}{l}0.126823 \\
(0.164)\end{array}$ & & $\begin{array}{c}0.106297 \\
(0.190)\end{array}$ & $\begin{array}{c}0.139206 \\
(0.204)\end{array}$ \\
\hline College_graduate & & $\begin{array}{c}0.118475 \\
(0.152)\end{array}$ & $\begin{array}{c}0.150951 \\
(0.166)\end{array}$ & & $\begin{array}{c}0.086010 \\
(0.193)\end{array}$ & $\begin{array}{c}0.126802 \\
(0.207)\end{array}$ \\
\hline Middle wealth & & $\begin{array}{c}0.044716 \\
(0.095)\end{array}$ & $\begin{array}{c}0.025330 \\
(0.100)\end{array}$ & & $\begin{array}{c}0.121512 \\
(0.106)\end{array}$ & $\begin{array}{c}0.114887 \\
(0.108)\end{array}$ \\
\hline High wealth & & $\begin{array}{c}0.102709 \\
(0.105)\end{array}$ & $\begin{array}{c}0.089883 \\
(0.108)\end{array}$ & & $\begin{array}{c}0.159149 \\
(0.108)\end{array}$ & $\begin{array}{c}0.154816 \\
(0.112)\end{array}$ \\
\hline $\begin{array}{l}\text { Excellent or very good } \\
\text { health }\end{array}$ & & $\begin{array}{c}-0.010630 \\
(0.077)\end{array}$ & $\begin{array}{c}-0.007524 \\
(0.078)\end{array}$ & & $\begin{array}{c}0.021492 \\
(0.081)\end{array}$ & $\begin{array}{r}0.025116 \\
(0.084)\end{array}$ \\
\hline Fair or poor health & & -0.231178 & -0.222436 & & -0.273686 & -0.263215 \\
\hline
\end{tabular}




\begin{tabular}{lcccccc}
\hline & $\mathbf{( 1 )}$ & $\mathbf{( 2 )}$ & $\mathbf{( 3 )}$ & $\mathbf{( 4 )}$ & $\mathbf{( 5}$ & $\mathbf{( 6 )}$ \\
VARIABLES & \multicolumn{7}{c}{ Retired about when had expected } \\
\hline \multirow{3}{*}{ Missing indicator: Wealth } & & $(0.101)^{\star \star}$ & $(0.106)^{\star \star}$ & & $(0.105)^{\star \star}$ & $(0.110)^{\star \star}$ \\
& & -0.366448 & -0.444033 & & -0.076309 & -0.113278 \\
& & $(0.124)^{\star \star \star}$ & $(0.152)^{\star \star \star}$ & & $(0.197)$ & $(0.210)$ \\
\hline Constant & 0.408866 & 0.053603 & 0.086904 & 0.185981 & -0.156190 & -0.140153 \\
& $(0.034)^{\star \star \star}$ & $(0.172)$ & $(0.190)$ & $(0.173)$ & $(0.279)$ & $(0.296)$ \\
\hline Observations & 209 & 209 & 209 & 188 & 188 & 188 \\
\hline
\end{tabular}

* Two-sided $\mathrm{p}$-value $<.10 ;{ }^{* *} \mathrm{p}<.05 ;{ }^{* \star *} \mathrm{p}<.01$.

NOTE: Numbers reported are regression coefficients, with standard errors in parentheses. 
Table B10a. Retired Later Than Expected

\begin{tabular}{|c|c|c|c|c|c|c|c|}
\hline \multirow[b]{2}{*}{ VARIABLES } & (1) & (2) & (3) & (4) & (5) & (6) & (7) \\
\hline & \multicolumn{7}{|c|}{ Retired later than had expected } \\
\hline \multirow{2}{*}{$\begin{array}{l}\text { Cognitive ability: Number } \\
\text { series }\end{array}$} & 0.000493 & & & 0.000266 & & & 0.000364 \\
\hline & $(0.001)$ & & & $(0.001)$ & & & $(0.001)$ \\
\hline \multirow{2}{*}{$\begin{array}{l}\text { Cognitive ability: Picture } \\
\text { vocabulary }\end{array}$} & & 0.001281 & & 0.001397 & & & 0.001265 \\
\hline & & $(0.001)^{\star \star}$ & & $(0.001)^{\star \star}$ & & & $(0.001)^{\star \star}$ \\
\hline \multirow{2}{*}{$\begin{array}{l}\text { Cognitive ability: Verbal } \\
\text { analogies }\end{array}$} & & & -0.000162 & -0.000706 & & & -0.000581 \\
\hline & & & $(0.001)$ & $(0.001)$ & & & $(0.001)$ \\
\hline \multirow[t]{2}{*}{ Focus on opportunities } & & & & & -0.022216 & & -0.019299 \\
\hline & & & & & $(0.011)^{\star \star}$ & & $(0.011)^{\star}$ \\
\hline \multirow[t]{2}{*}{ Focus on limitations } & & & & & -0.009416 & & -0.006105 \\
\hline & & & & & $(0.011)$ & & $(0.011)$ \\
\hline \multirow{2}{*}{$\begin{array}{l}\text { Social Security } \\
\text { expectations }\end{array}$} & & & & & & -0.000470 & -0.000421 \\
\hline & & & & & & $(0.000)$ & $(0.000)$ \\
\hline \multirow{2}{*}{$\begin{array}{l}\text { Missing indicator: } \\
\text { Cognitive abilities }\end{array}$} & 0.332952 & 0.788253 & -0.013983 & 0.624560 & & & 0.653202 \\
\hline & $(0.336)$ & $(0.305)^{\star \star}$ & $(0.319)$ & $(0.337)^{\star}$ & & & $(0.351)^{\star}$ \\
\hline \multirow{2}{*}{$\begin{array}{l}\text { Missing indicator: Future } \\
\text { time perspective }\end{array}$} & & & & & -0.141801 & & -0.115177 \\
\hline & & & & & $(0.086)^{\star}$ & & $(0.087)$ \\
\hline \multirow[t]{2}{*}{ Constant } & -0.207952 & -0.663253 & 0.138983 & -0.499560 & 0.186245 & 0.084700 & -0.412645 \\
\hline & $(0.314)$ & $(0.281)^{\star \star}$ & $(0.297)$ & $(0.316)$ & $(0.080)^{\star \star}$ & $(0.032)^{\star \star \star}$ & $(0.348)$ \\
\hline Observations & 303 & 303 & 303 & 303 & 303 & 303 & 303 \\
\hline
\end{tabular}

* Two-sided $\mathrm{p}$-value $<.10 ;{ }^{* \star} \mathrm{p}<.05 ;{ }^{\star \star \star} \mathrm{p}<.01$.

NOTE: Numbers reported are regression coefficients, with standard errors in parentheses. 
Table B10b. Retired Later Than Expected

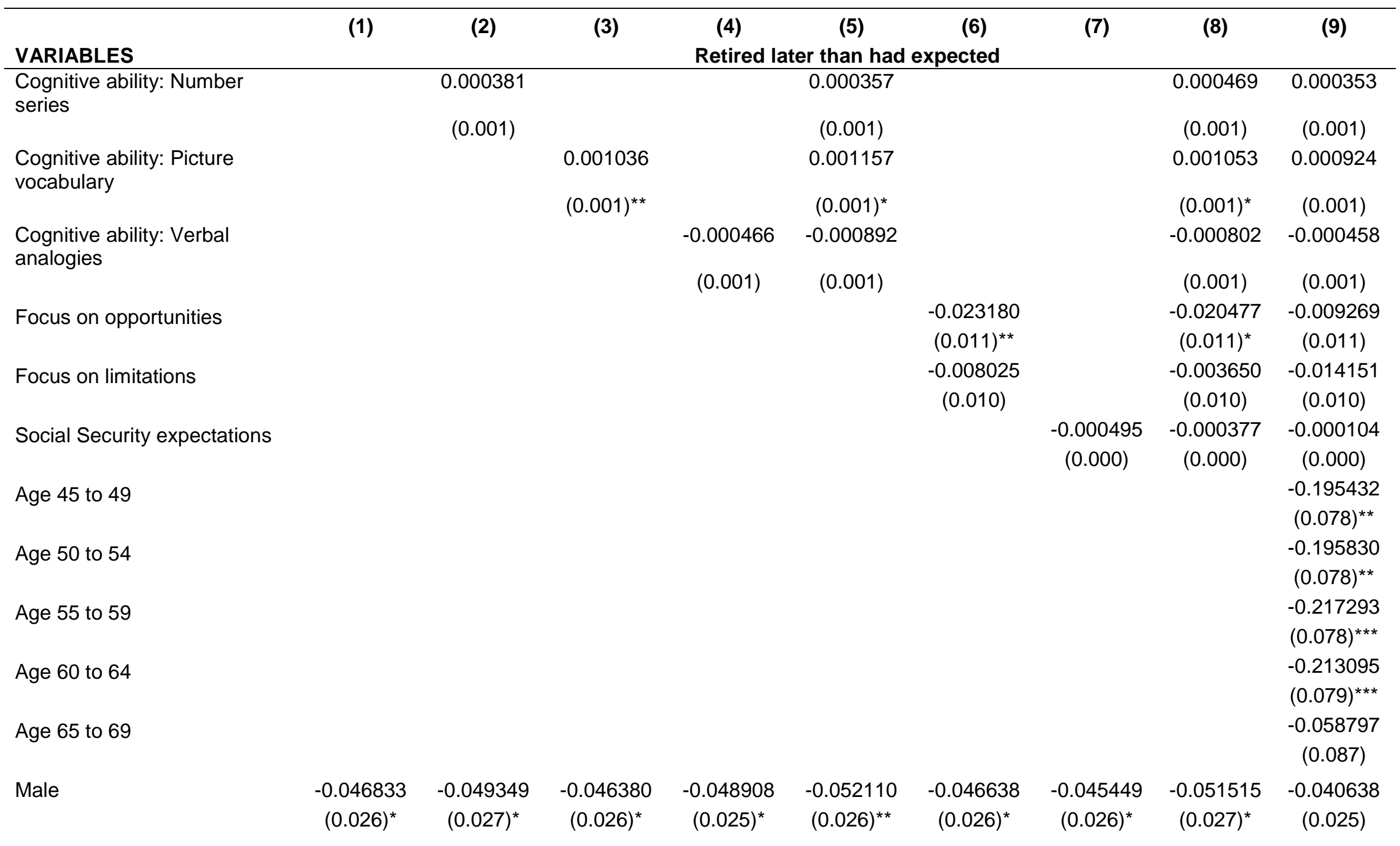




\begin{tabular}{|c|c|c|c|c|c|c|c|c|c|}
\hline \multirow[b]{2}{*}{ VARIABLES } & (1) & (2) & (3) & (4) & (5) & (6) & (7) & (8) & (9) \\
\hline & \multicolumn{9}{|c|}{ Retired later than had expected } \\
\hline Married & $\begin{array}{c}0.004319 \\
(0.039)\end{array}$ & $\begin{array}{c}0.001000 \\
(0.039)\end{array}$ & $\begin{array}{c}-0.002399 \\
(0.039)\end{array}$ & $\begin{array}{c}0.006803 \\
(0.037)\end{array}$ & $\begin{array}{c}0.001617 \\
(0.037)\end{array}$ & $\begin{array}{c}0.002133 \\
(0.039)\end{array}$ & $\begin{array}{c}0.005231 \\
(0.038)\end{array}$ & $\begin{array}{c}-0.000243 \\
(0.037)\end{array}$ & $\begin{array}{c}0.030534 \\
(0.041)\end{array}$ \\
\hline Divorced & $\begin{array}{c}0.013667 \\
(0.048)\end{array}$ & $\begin{array}{c}0.013146 \\
(0.048)\end{array}$ & $\begin{array}{c}0.014191 \\
(0.048)\end{array}$ & $\begin{array}{c}0.017484 \\
(0.046)\end{array}$ & $\begin{array}{c}0.019861 \\
(0.045)\end{array}$ & $\begin{array}{c}0.014489 \\
(0.048)\end{array}$ & $\begin{array}{c}0.014815 \\
(0.048)\end{array}$ & $\begin{array}{c}0.020599 \\
(0.045)\end{array}$ & $\begin{array}{c}0.011878 \\
(0.046)\end{array}$ \\
\hline High school graduate & $\begin{array}{c}0.051654 \\
(0.029)^{\star}\end{array}$ & $\begin{array}{l}0.065247 \\
(0.033)^{\star \star}\end{array}$ & $\begin{array}{c}0.056491 \\
(0.034)^{\star}\end{array}$ & $\begin{array}{l}0.069402 \\
(0.034)^{\star \star}\end{array}$ & $\begin{array}{c}0.061632 \\
(0.035)^{\star}\end{array}$ & $\begin{array}{c}0.049913 \\
(0.030)^{\star}\end{array}$ & $\begin{array}{c}0.054678 \\
(0.030)^{\star}\end{array}$ & $\begin{array}{c}0.060369 \\
(0.036)^{\star}\end{array}$ & $\begin{array}{l}0.095109 \\
(0.041)^{\star \star}\end{array}$ \\
\hline At least some college & $\begin{array}{c}0.041168 \\
(0.027)\end{array}$ & $\begin{array}{c}0.056723 \\
(0.032)^{\star}\end{array}$ & $\begin{array}{c}0.047259 \\
(0.032)\end{array}$ & $\begin{array}{c}0.059239 \\
(0.033)^{\star}\end{array}$ & $\begin{array}{c}0.052000 \\
(0.032)\end{array}$ & $\begin{array}{c}0.041155 \\
(0.028)\end{array}$ & $\begin{array}{c}0.041496 \\
(0.027)\end{array}$ & $\begin{array}{c}0.050552 \\
(0.034)\end{array}$ & $\begin{array}{l}0.102290 \\
(0.041)^{\star \star}\end{array}$ \\
\hline College_graduate & $\begin{array}{c}0.022197 \\
(0.026)\end{array}$ & $\begin{array}{c}0.030884 \\
(0.031)\end{array}$ & $\begin{array}{c}0.021920 \\
(0.030)\end{array}$ & $\begin{array}{c}0.041010 \\
(0.034)\end{array}$ & $\begin{array}{c}0.031115 \\
(0.032)\end{array}$ & $\begin{array}{c}0.028496 \\
(0.027)\end{array}$ & $\begin{array}{c}0.023703 \\
(0.026)\end{array}$ & $\begin{array}{c}0.034582 \\
(0.034)\end{array}$ & $\begin{array}{l}0.081696 \\
(0.040)^{\star \star}\end{array}$ \\
\hline Middle wealth & $\begin{array}{c}-0.013257 \\
(0.027)\end{array}$ & $\begin{array}{c}-0.019233 \\
(0.028)\end{array}$ & $\begin{array}{c}-0.022820 \\
(0.028)\end{array}$ & $\begin{array}{c}-0.012720 \\
(0.027)\end{array}$ & $\begin{array}{c}-0.021519 \\
(0.028)\end{array}$ & $\begin{array}{c}-0.017920 \\
(0.028)\end{array}$ & $\begin{array}{c}-0.009800 \\
(0.027)\end{array}$ & $\begin{array}{c}-0.024871 \\
(0.028)\end{array}$ & $\begin{array}{c}-0.021091 \\
(0.027)\end{array}$ \\
\hline High wealth & $\begin{array}{c}0.060386 \\
(0.039)\end{array}$ & $\begin{array}{c}0.052526 \\
(0.040)\end{array}$ & $\begin{array}{c}0.046186 \\
(0.040)\end{array}$ & $\begin{array}{c}0.061164 \\
(0.039)\end{array}$ & $\begin{array}{c}0.046348 \\
(0.039)\end{array}$ & $\begin{array}{c}0.052392 \\
(0.040)\end{array}$ & $\begin{array}{c}0.063427 \\
(0.039)\end{array}$ & $\begin{array}{c}0.039280 \\
(0.039)\end{array}$ & $\begin{array}{c}0.029690 \\
(0.036)\end{array}$ \\
\hline Excellent or very good health & $\begin{array}{c}-0.032344 \\
(0.034)\end{array}$ & $\begin{array}{c}-0.029638 \\
(0.035)\end{array}$ & $\begin{array}{c}-0.027353 \\
(0.034)\end{array}$ & $\begin{array}{c}-0.029264 \\
(0.034)\end{array}$ & $\begin{array}{c}-0.024236 \\
(0.034)\end{array}$ & $\begin{array}{c}-0.023066 \\
(0.034)\end{array}$ & $\begin{array}{c}-0.031305 \\
(0.034)\end{array}$ & $\begin{array}{c}-0.014825 \\
(0.034)\end{array}$ & $\begin{array}{c}-0.017609 \\
(0.031)\end{array}$ \\
\hline Fair or poor health & $\begin{array}{l}-0.077978 \\
(0.029)^{\star \star \star}\end{array}$ & $\begin{array}{l}-0.080764 \\
(0.030)^{\star \star \star}\end{array}$ & $\begin{array}{l}-0.077171 \\
(0.029)^{\star \star \star}\end{array}$ & $\begin{array}{l}-0.082722 \\
(0.029)^{\star \star \star}\end{array}$ & $\begin{array}{l}-0.075949 \\
(0.029)^{\star \star \star}\end{array}$ & $\begin{array}{l}-0.080016 \\
(0.031)^{\star \star \star}\end{array}$ & $\begin{array}{l}-0.077746 \\
(0.029)^{\star \star \star}\end{array}$ & $\begin{array}{c}-0.078867 \\
(0.031)^{\star \star}\end{array}$ & $\begin{array}{c}-0.057666 \\
(0.028)^{\star \star}\end{array}$ \\
\hline $\begin{array}{l}\text { Missing indicator: Cognitive } \\
\text { abilities }\end{array}$ & & $\begin{array}{l}0.313465 \\
(0.369)\end{array}$ & $\begin{array}{l}0.688199 \\
(0.293)^{\star \star}\end{array}$ & $\begin{array}{l}-0.133275 \\
(0.305)\end{array}$ & $\begin{array}{l}0.480115 \\
(0.328)\end{array}$ & & & $\begin{array}{c}0.515148 \\
(0.332)\end{array}$ & $\begin{array}{c}0.597709 \\
(0.339)^{\star}\end{array}$ \\
\hline $\begin{array}{l}\text { Missing indicator: Future time } \\
\text { perspective }\end{array}$ & & & & & & $\begin{array}{c}-0.125347 \\
(0.080)\end{array}$ & & $\begin{array}{c}-0.098113 \\
(0.080)\end{array}$ & $\begin{array}{c}-0.113848 \\
(0.078)\end{array}$ \\
\hline Missing indicator: Wealth & $\begin{array}{c}0.125174 \\
(0.130)\end{array}$ & $\begin{array}{c}0.122404 \\
(0.132) \\
\end{array}$ & $\begin{array}{c}0.115818 \\
(0.124)\end{array}$ & $\begin{array}{c}0.129198 \\
(0.130)\end{array}$ & $\begin{array}{c}0.111107 \\
(0.123) \\
\end{array}$ & $\begin{array}{c}0.138211 \\
(0.130)\end{array}$ & $\begin{array}{c}0.128859 \\
(0.130)\end{array}$ & $\begin{array}{c}0.121877 \\
(0.122) \\
\end{array}$ & $\begin{array}{c}0.143877 \\
(0.115) \\
\end{array}$ \\
\hline Constant & $\begin{array}{c}0.045223 \\
(0.035) \\
\end{array}$ & $\begin{array}{c}-0.164571 \\
(0.351) \\
\end{array}$ & $\begin{array}{l}-0.530991 \\
(0.267)^{\star \star}\end{array}$ & $\begin{array}{c}0.266432 \\
(0.303) \\
\end{array}$ & $\begin{array}{c}-0.330788 \\
(0.324) \\
\end{array}$ & $\begin{array}{l}0.169620 \\
(0.084)^{\star \star}\end{array}$ & $\begin{array}{c}0.069726 \\
(0.049) \\
\end{array}$ & $\begin{array}{c}-0.259664 \\
(0.340) \\
\end{array}$ & $\begin{array}{c}-0.227904 \\
(0.349) \\
\end{array}$ \\
\hline Observations & 303 & 303 & 303 & 303 & 303 & 303 & 303 & 303 & 303 \\
\hline
\end{tabular}

* Two-sided $\mathrm{p}$-value $<$.10*** $\mathrm{p}<0.05 \cdot * \star * * \mathrm{p}<.01$.

NOTE: Numbers reported are regression coefficients, with standard errors in parentheses. 
Table B10c. Retired Later Than Expected

\begin{tabular}{|c|c|c|c|c|c|c|}
\hline \multirow[b]{2}{*}{ VARIABLES } & (1) & (2) & (3) & (4) & (5) & (6) \\
\hline & \multicolumn{6}{|c|}{ Retired later than had expected } \\
\hline \multirow[t]{2}{*}{ Financial literacy index } & 0.001 & -0.003 & -0.006 & & & \\
\hline & $(0.009)$ & $(0.011)$ & $(0.011)$ & & & \\
\hline \multirow{2}{*}{$\begin{array}{l}\text { Maximizing: having high } \\
\text { standards }\end{array}$} & 0.000984 & -0.003135 & -0.005854 & & & \\
\hline & $(0.009)$ & $(0.011)$ & $(0.011)$ & & & \\
\hline \multirow{2}{*}{$\begin{array}{l}\text { Maximizing: continual } \\
\text { search }\end{array}$} & & & & -0.027037 & -0.030666 & -0.030889 \\
\hline & & & & $(0.015)^{\star}$ & $(0.018)^{\star}$ & $(0.018)^{\star}$ \\
\hline \multirow{2}{*}{$\begin{array}{l}\text { Maximizing: decision } \\
\text { difficulty }\end{array}$} & & & & 0.008028 & 0.012040 & 0.022791 \\
\hline & & & & $(0.023)$ & $(0.024)$ & $(0.022)$ \\
\hline \multirow{2}{*}{ Age 45 to 49} & & & -0.225530 & & & -0.266002 \\
\hline & & & $(0.131)^{\star}$ & & & $(0.163)$ \\
\hline \multirow[t]{2}{*}{ Age 50 to 54} & & & -0.170849 & & & -0.181998 \\
\hline & & & $(0.106)$ & & & $(0.122)$ \\
\hline \multirow[t]{2}{*}{ Age 55 to 59} & & & -0.174377 & & & -0.187755 \\
\hline & & & $(0.100)^{\star}$ & & & $(0.113)^{\star}$ \\
\hline \multirow[t]{2}{*}{ Age 60 to 64} & & & -0.162802 & & & -0.193427 \\
\hline & & & $(0.106)$ & & & $(0.123)$ \\
\hline \multirow[t]{2}{*}{ Age 65 to 69} & & & 0.047641 & & & 0.054250 \\
\hline & & & $(0.121)$ & & & $(0.138)$ \\
\hline \multirow[t]{2}{*}{ Male } & & -0.041063 & -0.034874 & & -0.037138 & -0.032284 \\
\hline & & $(0.033)$ & $(0.030)$ & & $(0.032)$ & $(0.029)$ \\
\hline \multirow[t]{2}{*}{ Married } & & 0.011152 & 0.038143 & & 0.014926 & 0.032156 \\
\hline & & $(0.052)$ & $(0.062)$ & & $(0.074)$ & $(0.084)$ \\
\hline \multirow[t]{2}{*}{ Divorced } & & 0.043659 & 0.018657 & & 0.064584 & 0.035660 \\
\hline & & $(0.066)$ & $(0.072)$ & & $(0.088)$ & $(0.096)$ \\
\hline \multirow[t]{2}{*}{ High school graduate } & & 0.072407 & 0.127257 & & 0.075699 & 0.164454 \\
\hline & & $(0.037)^{\star}$ & $(0.058)^{\star \star}$ & & $(0.051)$ & $(0.078)^{\star \star}$ \\
\hline \multirow[t]{2}{*}{ At least some college } & & 0.038582 & 0.103304 & & 0.039017 & 0.146560 \\
\hline & & $(0.035)$ & $(0.053)^{\star}$ & & $(0.045)$ & $(0.073)^{\star \star}$ \\
\hline \multirow[t]{2}{*}{ College_graduate } & & 0.023795 & 0.080925 & & 0.030550 & 0.126731 \\
\hline & & $(0.031)$ & $(0.055)$ & & $(0.049)$ & $(0.078)$ \\
\hline \multirow[t]{2}{*}{ Middle wealth } & & 0.010027 & -0.004299 & & 0.008370 & 0.002972 \\
\hline & & $(0.030)$ & $(0.032)$ & & $(0.036)$ & $(0.036)$ \\
\hline \multirow[t]{2}{*}{ High wealth } & & 0.073268 & 0.060882 & & 0.079783 & 0.057045 \\
\hline & & $(0.049)$ & $(0.046)$ & & $(0.057)$ & $(0.049)$ \\
\hline \multirow{2}{*}{$\begin{array}{l}\text { Excellent or very good } \\
\text { health }\end{array}$} & & -0.007708 & 0.004867 & & 0.003121 & 0.003710 \\
\hline & & $(0.039)$ & $(0.036)$ & & $(0.043)$ & $(0.037)$ \\
\hline Fair or poor health & & -0.077594 & -0.047720 & & -0.076230 & -0.065827 \\
\hline
\end{tabular}




\begin{tabular}{lcccccc}
\hline & $\mathbf{( 1 )}$ & $\mathbf{( 2 )}$ & $\begin{array}{c}\mathbf{( 3 )} \\
\text { VARIABLES }\end{array}$ & \multicolumn{7}{c}{$\begin{array}{c}\mathbf{( 4 )} \\
\text { Retired later than had expected }\end{array}$} & $\mathbf{( 5 )}$ \\
\hline \multirow{2}{*}{ Missing indicator: Wealth } & & $(0.036)^{\star \star}$ & $(0.033)$ & & $(0.037)^{\star \star}$ & $(0.039)^{\star}$ \\
& & 0.259429 & 0.267732 & & 0.170370 & 0.183759 \\
& & $(0.206)$ & $(0.186)$ & & $(0.176)$ & $(0.161)$ \\
\hline Constant & 0.061799 & -0.000650 & 0.040277 & 0.115203 & 0.036511 & 0.049820 \\
& $(0.017)^{\star \star *}$ & $(0.062)$ & $(0.090)$ & $(0.119)$ & $(0.141)$ & $(0.138)$ \\
\hline Observations & 209 & 209 & 209 & 188 & 188 & 188 \\
\hline
\end{tabular}

* Two-sided $\mathrm{p}$-value $<.10 ;{ }^{* *} \mathrm{p}<.05 ;{ }^{* \star \star} \mathrm{p}<.01$.

NOTE: Numbers reported are regression coefficients, with standard errors in parentheses. 


\section{References}

Brown, J. R., Coile, C. C., \& Weisbeener, S. J. (2010). The Effect of Inheritance Receipt on Retirement. The Review of Economics and Statistics, 92(2), 425-434.

Bruine de Bruin, W., Fischhoff, B., Millstein, S., \& Halpern-Felsher, B. (2000). Verbal and numerical expressions of probability: “It's a fifty-fifty chance.” Organizational Behavioral and Human Decision Processes, 81, 115-131.

Bruine de Bruin, W., Parker, A. M., \& Fischhoff, B. (2007). Individual differences in Adult Decision-Making Competence. Journal of Personality and Social Psychology, 92, 938-956.

Bruine de Bruin, W., Parker, A.M., \& Fischhoff, B. (2012). Explaining adult age differences in decision-making competence. Journal of Behavioral Decision Making, 25, 352-360.

Carstensen, L.L. (2006). The influence of a sense of time on human development. Science, 312, 1913-1915.

Carstensen, L., \& Lang, F. R. (1996). Future time perspective scale. Unpublished manuscript, Stanford University, Stanford: CA.

Cate, R.A., \& John, O.P. (2007). Testing models of the structure and development of future time perspective: Maintaining the focus on opportunities in middle age. Psychology and aging, 22, 186-201.

Disney, R., Emmerson, C., \& Wakefield, M. (2006) Ill health and retirement in Britain: A panel data-based analysis. Journal of Health Economics, 25(4), 621-649.

Finucane, M. L., \& Gullion, C. M. (2010). Developing a tool for measuring the decision-making competence of older adults. Psychology and Aging, 25(2), 271-288.

Fischhoff, B., \& Beyth-Marom, R. (1983). Hypothesis evaluation from a Bayesian perspective. Psychological Review, 90, 239-260.

French, E. (2005). The effects of health, wealth, and wages on labour supply and retirement behaviour. The Review of Economic Studies, 72(2), 395-427.

Gruber, J., \& Wise, D.A. (1999). Social Security and Retirement Around the World. Chicago: University of Chicago Press, 1999.

Henninger, D. E., Madden, D. J., \& Huettel, S. A. (2010). Processing speed and memory mediate age-related differences in decision making. Psychology and Aging, 25(2), 262-270. 
Hess, T. M., Queen, T. L, \& Patterson, T. R. (2012). To Deliberate or Not to Deliberate: Interactions Between Age, Task Characteristics, and Cognitive Activity on Decision Making. Journal of Behavioral Decision Making, 25, 29-40.

Hurd, M. D. (2009). Subjective probabilities in household surveys. Annual Review of Economics, 1, 543-562.

Hurd, M., McFadden, D., \& Gan, L. (1998). Subjective Survival Curves and Life Cycle Behavior. In David A. Wise (Ed.), Inquiries in the Economics of Aging. Chicago: University of Chicago Press, pp. 259-305.

Knoll, M.A.Z. (2011). Behavioral and psychological aspects of the retirement decision. Social Security Bulletin, 71, 15-32.

Iyengar, S. S., Wells, R. E., \& Schwartz, B. (2006). Doing better but feeling worse. Looking for the "best” job undermines satisfaction. Psychological Science, 17, 143-150.

Lillard, L.A., \& Willis, R.J. (2001). Cognition and wealth: The importance of probabilistic thinking. MRRC Working Paper No. 2001-07.

Lusardi, A., \& Mitchell, O.S. (2007, October). Financial literacy and retirement planning: New evidence from the RAND American Life Panel. MRRC Working Paper No. 2007-157.

Manski, C.F. (2004). Measuring expectations. Econometrica, 72, 1329-1376.

McArdle, J.J., Ferrer-Caja, E., Hamagami, F. \& Woodcock, R.W. (2002). Comparative longitudinal multilevel structural analyses of the growth and decline of multiple intellectual abilities over the life-span. Developmental Psychology, 38 , 115-142.

Nenkov, G.Y., Morrin, M., Ward, A., Schwartz, B., \& Hulland, J. (2008). A short form of the Maximization Scale: Factor structure, reliability, and validity studies. Judgment and Decision Making, 3, 371-388.

Parker, A.M., Bruine de Bruin, W., \& Fischhoff, B. (2007). Maximizers versus satisficers: Decision-making styles, competence, and outcomes. Judgment and Decision Making, 2, 342-350.

Parker, A. M., \& Fischhoff, B. (2005). Decision-making competence: External validation through an individual-differences approach. Journal of Behavioral Decision Making, 18, 127.

Schwartz, B. Ward, A., Monterosso, J. Lyubomirsky, S., White, K., \& Lehman, D. R. (2002). Maximizing versus satisficing: Happiness is a matter of choice. Journal of Personality and Social Psychology, 83, 1178-1197.

Wood, S., Hanoch, Y., Barnes, A., Liu, P., Cummings, J., Bhattacharya, C., \& Rice, T. (2011). Numeracy and Medicare Part D: The importance of choice and literacy for numbers in 
optimizing decision making for Medicare's prescription drug program. Psychology and Aging, 26(2), 295-307.

Woodcock, R. W., McGrew, K. S., \& Mather, N. (2001). Woodcock-Johnson III Tests of Cognitive Abilities. Itasca, IL: Riverside Publishing. 